\title{
ARTS AND CULTURE AS PARTS OF THE CIVILIZING PROCESSES AT THE TURN OF MILLENNIUM
}

Collective monograph

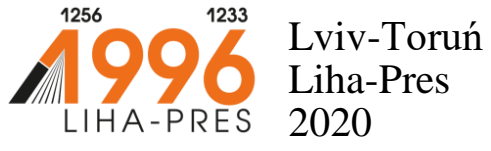




\section{Reviewers:}

Prof. nadzw., dr hab. Stanistaw Kunikowski, Rektor of Cuiavian University in Wloclawek (Republic of Poland);

Prof. $d r$ hab. Kazimierz Pierzchala, Katolicki Uniwersytet Lubelski/Catholic University of Lublin (Republic of Poland);

Prof. dr hab. Stanislaw Juszczyk, Uniwersytet Śląsi / University of Silesia (Republic of Poland).

Arts and culture as parts of the civilizing processes at the turn of millennium : collective monograph / M. Poplavskyi, T. Humeniuk, Yu. Horban, I. Bondar, A. Furdychko, etc. - Lviv-Toruń : Liha-Pres, 2020. $196 \mathrm{p}$.

ISBN 978-966-397-197-1

\section{SENSE}

Liha-Pres is an international publishing house which belongs to the category "C" according to the classification of Research School for Socio-Economic and Natural Sciences of the Environment (SENSE) [isn: 3943, 1705, 1704, 1703, 1702, 1701; prefixMetCode: 978966397]. Official website www.sense.nl. 


\section{CONTENTS}

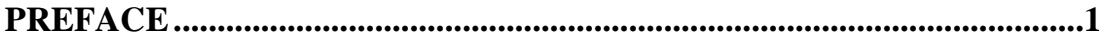

CONCEPTUAL FOUNDATIONS OF DUAL EDUCATION

IN HIGHER EDUCATION ESTABLISHMENTS:

KYIV NATIONAL UNIVERSITY OF CULTURE

AND ARTS EXPERIENCE IN THE EUROPEAN VECTOR

Poplavskyi Mykhailo 4

THE CULTURE AT THE BEGINNING OF THE NEW

MILLENNIUM FROM THE PERSPECTIVE

OF ,THE SURVIVOR”: A FUNDAMENTAL BREAK

IN THE SECRET CODE OF AESTHETICS.

UKRAINIAN EXPERIENCE

Humeniuk Tetiana

INFORMATION AND ADVERTISING DISCOURSE

AS A PHENOMENON OF CULTURE

Horban Yurii

DESIGN AND ARCHITECTURE IN THE AGE

OF POSTMODERNISM

Bondar Ihor 68

KOBZARDOM AS A PHENOMENON OF UKRAINIAN CULTURE IN THE CONTEXT OF THE NEW REALITIES

OF DEMOCRATIZED SOCIETY

Furdychko Andrii

THE THEATER CONCEPT IN MODERN CULTURAL SPACE

Ishchenko Yevhenii

THE PECULIARITIES OF BANDURA SOUND PRODUCTION:

THEORETICAL AND PRACTICAL ASPECTS

Broiako Nadiia. 
THE ART OF BOOK IN THE 17th-18th CENTURIES

Karakoz Olena

KYIV THEATRE AND ENTERTAINMENT SPACES

IN THE PERIOD FROM THE ELEVENTH TO EARLY

TWENTIETH CENTURIES

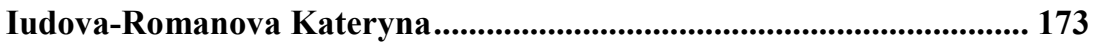




\section{PREFACE}

It is the need of today, on the one hand, to provide studies in theory, history and practice of arts within a broad cultural-cognitive context, and, on the other, to form up cultural concepts on the solid foundation of modern, common humanitarian scientific knowledge. This current tendency of an integrated interdisciplinary approach to the background of the theory and history issues of culture and arts is clearly reflected in the articles presented by famous scientists, philosophers, culture scientists, art historians of the Kyiv National University of Culture and Arts.

The authoring team have offered a wide range of issues related to cultural and creative processes in Ukraine and in the world. The research range of the presented chapters of the monograph involves searching for the path-dependent patterns for the cultural studies in Ukraine: to study the current state and conceptual frameworks of arts and cultural education; to expand the discourse of cultural studies and art criticism; to test it in the study of specific phenomena of the cultural advancement of humankind; to reveal the cultural model evolution of the arts and the art world; to clarify the spiritual bonds of cultural activity within the worldperception and world-view transformations at the end of the 20th -21 th centuries.

These issues of development of contemporary culture, to mention but a few, require considerable efforts of philosophers, cultural scientists, aesthetician, ethician, sociologists, political scientists and representatives of other social and human sciences in the transformation processes perception that relate both to the target academic issues, and to the study of world culture and art culture issues, in particular, as a basis for artistic activity and its influence on the study of the criteria of artistic and aesthetic values of contemporary art.

The chronological and geographical range of research, published in the collection of research papers, is wide enough: from a culture of the Early Modern Period to the latest phenomena and trends of postpostmodernism as a transcultural phenomenon. In this range, there are significant issues of culture form as a transformation of social and cultural sphere in the information society, civilizational challenges of the 20th century, topical issues of historical development and current state of Ukrainian national artistic culture, at last, the transformation processes in culture at the turn of the Millennium, projected on the realities of life of the Ukrainian society. 
One of the most significant factors that has a significant impact on the civilization process in terms of time is compulsive and increasing dynamics of improvement of various forms of scientific knowledge, and at the same time, strange as it may seem it is largely paradoxical combination of diverse practices of rational and irrational framed strategic objectives of social development. And as a consequence of a combination of circumstances, of subjective and objective nature of resonant tonality in the modern cultural development of mankind can specify the determinants of irrational content, which usually require rational reasoning, scientifically formed system of evidence and argument. Therefore, in this case, the ever-increasing authority of science is used as an effective tool to justify the aims that are often inhumane. And this results in both spiritual and massive military conflicts. Since the modern world is highly integrated, it is putting not only individual communities, and countries but also the whole world at risk.

As noted by contemporary American scientist A. Toffler, people often do not have time to adapt to everything that happens to them in the modern world, they are in a state of future shock, which is inexorably staring at their faces, dictating them new ways of spiritual non-self perception, experience and existence in it, which have been impossible so far.

The temporal dimension of human existence in the world acquires new forms. This is reflected in appropriate cultural forms and real-life of human existence in the world. Contemporary culture sorely requires synthesis of time samples where a human can fix in the realities a fact of culture evidence through the historical stages of world development and today it can be a clue to scientists who are addressing the advanced issues. Possible future steps in the cultural development influence actively the present solution searching for Universe existence.

The publication of the joint monograph of teacher-scholars of the Kyiv National University of Culture and Arts is an important event in the educational and scientific life of the University. This scientific publication is to be an essential component in the development of the high potential of the scholastic institution and designed to shape not only specific scientific fields (and at the University there is a wide list of the departments with relevant academic and art guild of expert teachers), but also to create a limitless framework for scientific social environment as part of the invisible "aura of the arts" (L. Kostenko), through which culture, as in a mirror, produces three-dimensional picture of itself. 
It is the hope of the authoring team that presented monograph will favour the integration of scientific and humanitarian knowledge and intensification of cultural and creative processes in Ukraine and will be of interest to the professional cultural and artistic community and a wide audience. 


\section{CONCEPTUAL FOUNDATIONS OF DUAL EDUCATION IN HIGHER EDUCATION ESTABLISHMENTS: KYIV NATIONAL UNIVERSITY OF CULTURE AND ARTS EXPERIENCE IN THE EUROPEAN VECTOR}

\section{Poplavskyi Mykhailo}

\section{INTRODUCTION}

The concept of dual education, the strategy of launching its individual elements in the HEA and, for that reason, studying European and world experience has been the agenda of the professional community in Ukraine's educational space for several years. Having started from "the top", being reflected in the updated legislative framework (Law of Ukraine "On Education", in the Government Action Plan for the period 2017-2020, in the order of the Ministry of Education and Science of Ukraine "On Approval of the Concept of Training Specialists in the Dual Form of Education"), the process of comprehension and implementation of dual education gradually changes the established ideas about the activity of higher education, becomes the subject of discussions and debates, directly influencing the development and approval of educational plans and programs for specific areas, specialities and specializations.

During the active debating over the past five years within the domestic professional community, a sufficient number of common positions and approaches to dual education in the Universities were presented (L. Hrynevych ${ }^{1}$, L. Krymchak ${ }^{2}$, N. Svitailo ${ }^{3}$ ), the experience of European

${ }^{1}$ Hrynevych L. Kontseptsiia pidhotovky fakhivtsiv za dualnoiu formoiu zdobuttia osvity [The concept of training specialists in the dual form of education]. Retrieved from: https://btsau.edu.ua/sites/default/files/Faculties/osvita/dualna/pidgotovkifakhivtsiv-za-dualnoyu-formoyu.pdf (accessed 26 January 2020).

${ }^{2}$ Krymchak L. (2019) Systema dualnoi osvity yak umova yakisnoi pidhotovky konkurentospromozhnykh profesionaliv na rynku pratsi v Ukraini [Dual education system as a condition for qualitative training of competitive professionals in the labour market in Ukraine]. Teoriia ta metodyka profesiinoi osvity, vol. 2, no. 11, pp. 83-86.

${ }^{3}$ Svitailo N. Dosvid Nimechchyny v pytanni reformuvannia osvity: dualna osvita [German experience in reforming education: dual education]. Friedrich Ebert Stiftung. Retrieved from: https://www.slideshare.net/omosvita/ss-62919443/ (accessed 26 January 2020). 
countries, countries of the world were compared (I. Boichevska ${ }^{4}$, I. Hlazkova \& I. Khyzhniak ${ }^{5}$ ), the prospects of its implementation in Ukraine are analyzed, the expediency and efficiency of dual education functioning within certain specialities and specializations, educational programs, etc. were predicted (I. Stoliarchuk ${ }^{6}$, I. Hardabkhadze ${ }^{7}$, I. Petrova ${ }^{8}$, T. Postoian ${ }^{9}$ ).

In the article we will cover and analyze the conceptual parameters of dual education, explore its formative and reformative role in higher education institutions of cultural and artistic orientation; On the example of the educational activity of the Kyiv National University of Culture and Arts, we will formulate the positive and negative consequences of its implementation as an educational form and as an educational model.

\section{Features and Stages of the Dual Education Introduction at the Kyiv National University of Culture and Arts Through the Prism of European and World Experience}

New Higher Education Standards and Accreditation Requirements for the Universities' specialities encourage to implement a new strategy in

${ }^{4}$ Boichevska I. (2009). Rol systemy dualnoi osvity u profesiinii pidhotovtsi molodi u Nimechchyny [The role of dual education in youth vocational training in Germany]. Porivnialno-pedahohichni studii, no. 2, pp. 68-74.

${ }^{5}$ Hlazkova I., Khyzhniak I. (2019). Stanovlennia teoretychnoho ta praktychnoho komponentiv dualnoi systemy osvity v Nimechchyni [Formation of theoretical and practical components of the dual education system in Germany]. Profesionalizm pedahoha: teoretychni ta metodychni aspekty, no. 9, pp. 70-83.

${ }^{6}$ Stoliarchuk I. (2019). Napriamky spivpratsi TsSN "PROKOM" ta ZVO. Dualna osvita yak proiekt yakisnoi pidhotovky IT-fakhivtsiv [Directions of cooperation between CSC "PROCOM" and ZVO. Dual education as a project of qualitative training of IT specialists]. Retrieved from: https://it-universe.org/ua/blog/Konf/ Conf2019/9_Напрямки\%20співпраці\%20ТОВ\%20Проком\%20та\%203ВО.\%20Ду альна\%20освіта.pdf (accessed 26 January 2020).

${ }^{7}$ Hardabkhadze I. (2018). Dualna osvita u feshn-dyzaini: problemy i perspektyvy [Dual education in fashion design: problems and perspectives]. Demiurh: idei, tekhnolohii, perspektyvy dyzainu, no. 1, pp. 59-72.

${ }^{8}$ Petrova I. V. (2019) Profesiina pidhotovka ivent-menedzheriv u konteksti dualnoi formy zdobuttia osvity [Training of event managers in the context of dual education]. Visnyk Kyivskoho natsionalnoho universytetu kultury i mystetstv. Seriia: Menedzhment sotsiokulturnoi diialnosti, vol. 2, no 1, pp. 82-104.

9 Postoian T. (2015). Dualna systema navchannia v umovakh haluzevoi klasteryzatsii [Dual training system in the conditions of branch clustering] Pedahohichni nauky: teoriia, istoriia, innovatsiini tekhnolohii, no. 2, pp. 374-382. 
curriculum development, putting a practical constant not only in the credit and module volumes of the curriculum but also in the educational technology model at all levels of education (in an auditorium, outside of it, in the workplace, on the job, in small groups). Modular course design is also a resource for creating the conditions for the introduction of a dual model (form) for higher education, as it allows segmenting the overall content of the subject from individual blocks-modules, and individual parts can change, freely "flowing" from one form of study to another, from theory to practice and vice versa. And such a feature of the modular system of the training course sets the necessary logic for constructing it as a transformer, which may contain different models and forms of conducting classes.

The very concept of dual education has several meanings that influence its understanding and interpretation. First of all, "duality" in education is understood as a system of combining training with industrial activity, work "in production". Secondly, it is a combination of theory and practice as two complementary stages of learning, their consistent alternation and consistent change. In the first embodiment. the emphasis is on duality as a system of education and in the second, it is on duality as a principle. Moreover, this principle can be part of another dual system and can be embodied in all sorts of other combinations and forms. Such predication of the duality's concept allows realizing the creation possibility of different forms, types and models of dual education, their combinations, which proves the necessity to take into account any peculiarities of individual educational programs, national educational spaces with their specific tasks and challenges.

Therefore, for the seemingly simple meaning of the concept of "dual education" as a combination of learning in a student audience with practice in the workplace (the so-called form of dual education), there is a difficult way of practical implementation of its forms (especially in the context of our difficult economic situation) and, moreover more vague search for its domestic paradigm - the educational model of dual education. The experience of Germany, Poland, Austria, Switzerland, Canada on this subject is undoubtedly worth knowing and studying. But in the formal inheritance of certain models (and are they the best for us?), we should not forget to take into account our own national realities, refining already developed our unique educational technologies.

And such practice exists at the Kyiv National University of Culture and Arts - especially this concerns the training of specialists for the field of the creative economy, which has always been "out" of general 
educational principles, existing and developing according to special rules. And in the modern world, requests for specialists in this sphere require the main thing - to be different from anyone, to be unique and, paradoxically, in such uniqueness to be stable and stable-dynamic. Thus, KNUC\&A takes endless steps to achieve this stable uniqueness, which, as it appears, can be "entrenched" in educational programs and put on a stream... This is the structural principle that, as a means of Macropulos, enables the University, on the one hand, to seek and assert "eternal" educational values (and to hold it firmly) and, on the other, at the same time, ironically, always to be an original, unsystematic, bifurcating "production" cluster of competitive and demanded talents in the real labour market ( the quantity and quality of which do not directly depend on economic performance, or from social expectations). And in such a paradoxical situation, dual education can be interpreted not only as a form of getting bachelor's, master's degree in combination of training and practice but as an educational model for improvement of practical super competences (universal competences) of a future specialist, who will need to work and compete in new, now uncertain principles of the labour market. However, the competence paradigm of education is now the basis for all major players in the world educational process, and we are repelled from it as we try to combine it with the fundamental national tradition.

The successful experience of the introduction of dual education in Germany, which became the prototype for all subsequent inheritances and borrowings, is based on the "philosophy of the profession", which for several centuries was formed at the intersection of their own national cultural traditions (the same "Protestant ethics" according to M. Weber). and the demands of the time in the need for specialist workers of particular (mostly engineering) specialities. The uniqueness of this form of acquisition of professional knowledge was characterized not only by the level of the profession's mastery: on the contrary, the "philosophy of the profession" was submitted so as to be "incomplete", that is, not to be limited to a set of specific skills and abilities, but to contain professional outlook and management strategies, awareness of personal responsibility in decision-making and, finally, creativity (and this we say, once again remind, about working professions!). The philosophy of the profession is also valid because it is in countries with a focus on this type of professional activity (and besides Germany, there are Austria, Switzerland, which also actively use dual education to solve a wide range of problems - unemployment, economic stability, happiness index 
(It is interesting that such indices are important factors in measuring the quality of education in Europe and the world. For example, on one of the most reputable assessment platforms for national PISA (Program for International Student Assessment) programs, monitoring results are necessarily presented through the prism of such indicators like the "positive feeling index", "he meaning of life index", "Index of feeling of belonging to educational institution" ", that is, those characteristics that are outside the actual focus of learning as such, but which create the necessary emotional and vital background for the effectiveness of educational interaction.)) and life satisfaction, etc. A diploma of graduation is not considered as an only possible argument for obtaining a prestigious and high-paying job and indulgence from future career and life problems. On the contrary, working specialities in the context of the philosophy of the profession make it possible to occupy a stable social niche, earning the necessary means to ensure a normal standard of living. And when we try to "raise" the dual education in our country, in the realities of our time, we must take into account this socio-cultural factor in order not to be surprised why a particular model of dual education works "there" but not "here". That is, the technical and material issue's side of introducing dual education in Ukraine will not necessarily be fundamental. Quite the opposite, cultural stereotypes and social expectations, that are general in the choice of the future place of study, should be taken into account.

However, such principle of the philosophy of the profession was also tested in the KNUC\&A training and educational process in the early 2000s. Of course, in our paternalistic tradition, it was hard for anyone to imagine at that time. We can personally recall those, who mocked the idea of training hairdressers, makeup artists at the University of Culture. And is not it possible to call it a form of dual education now, in the realities of today? And in our country, such a state of affairs and approach could have earlier raised and resolved the issue of the disproportionate relationship between establishments which train managers (as such, without reference to the specifics of professions) and vocational education, which is more stagnant than can to solve problems. This was the first step taken by the KNUC\&A management towards the

${ }^{10}$ Natsionalnyi zvit za rezultatamy mizhnarodnoho doslidzhennia yakosti osvity PISA [National Report on the Results of the International Study on the Quality of Education PISA] (2018). Retrieved from: http://testportal.gov.ua/wpcontent/uploads/ 2019/12/PISA_2018_Report_UKR.pdf (accessed 26 January 2020). 
introduction of dual education as a model of the complex competencies acquisition (universal and professional).

To implement this type of educational innovation, we needed to answer a few questions. First, how we needed to build curricula in order to give students thorough knowledge on the one hand, and, on the other, to legitimize "leaving" the classroom during the educational process, closer to life. In what way did we have to do it? How did we have to monitor and measure this type of learning outcomes? Second, there was the question of the lack of appropriate professionals who could become for students those stalker-guides, who freely flanked between theory and practice (and vice versa). The University validated this shortcoming in the educational trend, starting a wonderful tradition of inviting the best and the most successful professionals, masters, specialists in various fields (from the fashion industry, show business to IT, journalism, design, management) to teaching positions. And this experience served to gradually transform of teaching audiences into a creative workshop, a laboratory, a workshop: a person who is successful and confident in the profession can best transfer such experience (and not just knowledge, material, information) to others. By the way, in Germany and Switzerland, dual education programs employ staff who also have a relevant diploma in order to clearly adhere to the standards of professional practitioners training that have been established over the years. Also, the system of creative workshops became the first analogue in Ukraine of the organic approach of a potential employer to a higher education establishment, an informal dialogue between it and the educational institution as full-fledged subjects of the educational process.

The second step in the implementation of this model was the strategy of preparation and realization of artistic projects, which were in operation at the University for more than a year. When the concept of "dual education" did not yet exist in the national educational space, KNUC\&A actively involved specialists-practitioners from different fields - in addition to the more traditional and customary fields of theatrical arts, film and television industries, the first-class specialists of IT field, PR, hotel and restaurant industry, beauty industry and other fields of creative economy were encouraged for teaching and management of artistic projects. This educational and practical vector was designed in accordance with the concept of creative workshops developed by University management. This concept and practice of creative workshops in the aspect of the implementation of the dual education model can be positioned as a prototype of modern professional 
guilds led by a master. The master, who heads his creative workshop from the first year, attracts students not only to the "slums" of the future profession (forms professional competences), but also "immerses" the students in a world in which knowledge is not "given" (or that is the worse, "provided"), but acquired. The student, using all offered to him educational, pedagogical and educational arsenal, learns himself (and this skill is the basis of the symbolic capital that he will need throughout his life and which he will validate and apply in the world, in which the list of current professions is changed every 5-10 years). Also, the educational model of creative workshops is an example that unravels the current illusion that classroom training will be replaced in the near future by the viewing and processing of video materials - everything will be taught by computer technology. Of course, when it comes to the "echelon" type of knowledge representation as to information. Just a creative factor of any profession can grow only and exclusively in the lived experience of communication with the master, imitating not only his skill but also his style of communication, vital and workshop values.

The third step. An important feature of dual education is the use of project-based methods in the educational process: creative projects, training, workshops, presentations were included in the "body" of KNUC\&A educational programs and curricula a long time ago. A creative project, as a measure of the specificity of competencies acquired during training, becomes a social taximeter for their real value in the labour market. Not in words, but in practice, the student throughout the study through projects, training, dialogues with the master, gets rid of professional frustration - a bad companion of our youth in search of the first job. In the implementation of their own creative projects under the guidance of "field player" master-teacher students master various types of professional activity, gain experience of free partnership, affirm themselves as self-sufficient personalities who can and know something already. That is, during the training and implementation of the creative project, the student is guaranteed the experience of performing real work, which can be seen (and seen!) by real employers. In this model of presentations, festivals, concerts, students start competing with each other during their studies - but who said that it is bad? It should be borne in mind that this is, after all, a "friendly" "educational" competition, which does not concern the "root" system of human dignity and fundamental principles for education - to obtain the proper knowledge and skills in the conditions of mutual respect and trust. And the studentcentred teaching for the University of Culture is not an empty phrase: 
prospective students actively "vote" for it by the number of applications both for budget and studying at their own expense. And such an attractiveness of education in our university is an investment with a guaranteed result - the result of gaining complex knowledge and practical skills for successful competition in the modern labour market, which, as we have already noted, is desacralized for the University student, in which he is free-oriented, familiar (in person and absentia) with major players in the industry, realized their own value and rationalized their own professional shortcomings and skills on the way to self-improvement and self-realization.

This approach forms another direction of movement toward a dual model of education through an awareness of the principles of practical philosophy. It is known that the modern philosophy of education puts forward the principle of the practical application of knowledge beyond the classical hierarchy of two-tier sequence "theory- practice". The simplistic interpretation of this dyad vulgarizes the meaning of the practice (it is known that the concept of "praxis" in the tradition of Aristotle is translated as act, action, action), treating it merely as a "supplement" to the theory. In general, in the post-Kant world, it is strange to stand up again for the "practical mind", the "practical wisdom", explaining its importance as the basic ability of a person to freely and independently realize and solve vital problems and challenges. At least Kant believed, that a person is determined by his actions and behaviour. Accordingly, practical philosophy should not be correlated with applied: knowledge is not luggage, accumulated in the form of processed/read/outlined/abstracted data obtained from classic sources written by "white dead men" (ironically, this constant tradition of compiling lists of classics is marked by the non-classical humanitarian discourse). In such a superstructure over the theory, the practice looks like a stillborn baby.... On the contrary, the main idea of dual education in a modern university is to create an educational space for the intensification of thought and its adjustment to practical implementation (acquisition of so-called competencies) as the ability to analyze, argue, synthesize, interpret, compare, give examples, question, problematize. Moreover, the subject of the application of all the above-mentioned skills is a broad cultural and intellectual background - philosophical and literary and artistic texts, works of art, media, thoughts and beliefs, personal impressions and experience. Thus, the principles of a practically competent approach are fundamentally different from the knowledge acquisition approach. The transformation of experience into knowledge 
and vice versa at the point of their combination creates a "synergistic" transaction of educational and training efforts into liquid market competences in a particular profession, in a particular production, in a particular creative workshop.

The described feature was taken into account in the development of work programs of the dual form of study at KNUC\&A in all specialities. The main task of the developers was to bring all the practical and independent work of the student into a separate consistent strategy of mastering knowledge, skills and abilities. This approach was intended to eliminate the substantive disproportion between the student's theoretical knowledge and the practical skills that he/she should master during mastering the course. Also in the body of all training courses, an individual form of classes (approximately 4-6 hours per semester) was introduced... The training courses became the most indicative for the introduction of the dual educational model, which did not envisage the existence of lecture blocks at all. They were deliberately removed from the training course as a form of teaching, but the lecture content was retained as a general element of the course. Such "dissolution" of the lecture material allowed to acquire not only certain individual knowledge but to "translate" the capital of this knowledge and skills into the worldvalue plane. Socrates also proved the people of Athens thought of the value of only those knowledge that the person had received, by his own efforts, as if "remembering" himself. Such a "limitation" of the lecture material did not affect the content-theoretical content of the course in any way, other accents were simply placed - the basic knowledge was acquired together and at the same time with the acquisition of practical skills.

When it comes to creative professions, such as theatre, choreography, music, everything is clear - no matter how anyone listens to the lectures, but in the long run, you need to get up and play, show, dance. More revealing features of the dual model of learning can be understood by examples of its transformation in non-artistic specialities - law, IT, management, economics, international relations. Modular training programs, training, business projects, game and computer simulations were developed for all educational programs in the mentioned specialities, which, according to the developers, should compensate for the lack of practical professional skills and teach students to effectively use their educational skills. audiences of knowledge in a real professional environment. Moreover, the game elements of the course are quite organically combined with the "serious" thematic blocks of the discipline, such organics created a productive symbiosis of a 
"serious game" rather than a recreation game, a discharge game. And interestingly, this game model has also come to fruition in the way of evaluating student learning outcomes - in work programs, in addition to traditional scoring points, positions such as prize places for special individual achievements and team qualities are also provided (i.e. groups were evaluated separately projects). This type of practicum also created the effect of modularity of theory/practice due to the dynamic change of different forms of educational activity of students: each game period ends with a report-analysis of problematic issues of the course. That is, a written report takes into account the individual work of each student, as well as the results of the team as a whole. The report is also presented in the form of an oral presentation, during which an important element is answering the questions of the teacher, the participants of the project, the game, the training. Such a multimodal sequence of the course content transforms a traditional university course into a certain multimodal project, the implementation of which requires the student to constantly change activities and versatility in the application of knowledge, skills, attitudes and from the teacher dynamics, creativity, Socratic wisdom, in order to simultaneously model and present the complex in the simple, serious in the game, knowledge in life. Of course, we are aware of the complexity of implementing such an educational model (and even the Socrates at all, of course, will never be enough). On the example of changes in traditional working programs of dual training courses, we are aware of the need to introduce this type of educational innovations, their prospects for reforming the national educational space and the importance for successful competition in the modern realities of the universities of the knowledge economy. This course design allows students to avoid fragmentation in the understanding of the content of the educational program, to integrate each individual content modular fragments into the general educational outline. Duality also corresponds to the structural and logical scheme of the curriculum in general - any discipline is studied in combination with other disciplines of cycles of vocational and practical training in specialities and individual specializations.

\section{Consequences of Introducing Dual Education as an Educational Form and as an Educational Model}

The dual learning machine at the University can be understood by a certain feature: the university status of implementation of the dual education model is not in the mechanical combination of theory and 
practice, lectures and practical classes (as we have shown above, we abandoned such a mechanistic sequence). On the contrary, at the University conceptualization of knowledge and practical activity (ideally) are interrelated elements of any training course and discipline. Besides, this type of duality allows us to form another valuable universal competence - personal attitude to one's activity, value and ideological awareness of it, search for personal motivation to continue selfimprovement and to grow creatively.

The approach outlined above has prompted a rethinking of established views on university curricula. Nowadays there is a reduction in student workload, freeing up time for independent work. And dual education adds supplementary alternatives to the traditional and often ineffective "sitting in the audience" and this path becomes a good option against the background of permanent and multi-vector reform of the domestic education system, (which only the laziest is not joking about). Introduction of dual education as a new experimental form of education should be understood in a comprehensive, systematic manner, taking into account all the components of the specialist's training at the Universities, synchronizing the reform of the legal framework of education with the development and implementation of educational programs.

This philosophy of practice is particularly relevant because of the rapid change in the network of professions in demand. The focus on purely professional competences creates the risk, over a short period, of obtaining such specialists who, at the time of their first job search, become unnecessary or/and uncompetitive. And such a problem will only increase. At present, the idea, that institutional education potentially limits creativity, is widespread: "Competence in a particular field can be affected if it is too long to challenge basic assumptions. The price of this approach is the commitment to any one option. This means that you have associative barriers that mostly interfere with the formation of intersections of ideas". Accordingly, "specialization limits creativity". . This is why discussions in Western philosophy of education have been around for decades for so-called "soft" skills, which will be the only ones in demand in the future, remaining the constant of any education, for any speciality, in any educational establishment, After all, "soft" skills are the skills of relationship,

11 Yogansson F. (2008). Effekt Medichi: vozniknovenie innovatsiy na styike idey, kontseptsiy $i$ kultur [Medici effect: the emergence of innovation at the intersection of ideas, concepts and cultures]. Moscow: OOO "ID Vilyam S". 
communication and interaction in professional activity. In general, the "human factor" was always decisive in any field and situation. But in the face of modern technology and the dynamics of the modern professions, the "soft" skills from ancillary become basic competencies. This is especially true of the young people who grew up and evolved with the devices in their hand (i.e. modern adherents to the Universities). The fact is that the technique of "pushing" buttons with the rapid receipt of any information and any impressions has focused all life experience in virtual mode. But the field of activity is the sphere of human interaction (even if it is an actively mediated technique and technical means). Debra G. Isaacs says in the article "Hard Work, Soft Skills", "Today, there is a wheel of change regarding work skills. Nowadays, soft skills not only measure the quality of education but also turn into a marker of competitiveness, often prevailing over the socalled "hard" professional characteristics, as evidenced by surveys and reports of business executives. Such changes have also influenced the name's update. Now the practical skills of such type are called "working capacity" or "basic skills" professional will only be enhanced, and the quality of education of a particular higher education establishment in a specific speciality will be assessed soon to the extent of universal competences (basic skills, soft skills), that the future professional may realize during various workinteraction, such as man-man, man-machine, man-machine-man. That is why potential employers started to talk about revising the strategy of training professionals in specific industries. They were the first, who started "reaping the benefits" of a specialists' shortage who can study quickly and apply communication skills successfully. Their experience became a valuable request for the content of specific educational programs and areas of study, employers "entered" the educational territory as stakeholders and their interest influenced and continue to influence educational strategies and principles (at least, it took place in such a way with development and introduction of dual education in the educational European space of the late 2000s - early 2010s).

Such crossings and activities in the "foreign" territory are a common cultural tendency, a problem of the crisis of generations, education, socialization, worldviews and values. Also, the breadth of the problem

${ }^{12}$ Isaacs D. G. (2016). Hard jobs take soft skills. The line report. 2016. May, no. 16. Retrieved from: https://www.lanereport.com/63403/2016/05/hard-jobs-take-softskills/ (accessed 26 January 2020). 
does not accurately determine at what stage you need to learn soft skills - at family, school, college or school, at Universities' educational programs? Who has greater responsibility for results? It is clear that higher education is more pragmatic and "technical" in the process of providing soft skills, modelling its own universal competencies and learning outcomes. Also, "invisibility" and the lack of articulation of acquiring "soft" skills as such do not motivate students to master their skills. They believe that they already know how to communicate, think, understand and work, act in a team, etc.

Therefore, the University's mission (and this is our fifth step towards effective models of dual education) is to integrate soft skills into curricula through forms of play, training, competition, artistic project, creative activity as such. That is, it is impossible to limit "soft" skills only in the sphere of communication and interpersonal interaction, on the contrary, the substantive content of this concept is gradually expanding, adding to it such as "critical thinking", expediency of using resources, optimism, persistence, initiative, consistency ability to learn and develop.

In this context, I would like to give a witty example of Ruth Callaghan used at Melbourne's Middleton Business School to explain the essence of soft skills in the educational process. You need to compare two objects - a complex object called "Airbus 380" and a frog (also, to some extent, a complex object!). If you put a giant aircraft in a specially equipped hangar and the efforts of specialists disassemble it, then assemble it again, the aircraft will fly. Everything is different with the frog: "You have the opportunity to explore the frog in its environment, but we do not know what it is going to do next. It is probably hungry. Probably, it will be seen by another frog... That is, we have no way of predicting what will happen to it further, nor will we be able to disassemble it, gathering it again and hoping that everything will remain the same" 13. Thus Calligan proves that in the "extra-human" world the pattern works and spreads to all causes and effects. And the "world of people" is, on the contrary, the variability of actions that are not due to the given conditions. Therefore, "soft" skills are always the absence of one correct answer for the many variants of the situation's development.

${ }^{13}$ Callaghan R. (2017). Universities teach soft skills employers want to students of 'hard' disciplines. Financial Review Mar 30. Retrieved from: https://www.afr.com/work-and-careers/education/universities-teach-soft-skillsemployers-want-to-students-of-hard-disciplines-20170328-gv89hq (accessed 26 January 2020). 
But, of course, with the introduction of a dual education strategy, universal competencies have acquired the specificities of application and experience testing, and have been realized as meta professional qualities of a future specialist. It is not for nothing that the European concept of education gradually introduces another conceptual alternative - the socalled "useful" knowledge (The conceptual parameters of these concepts are devoted to the article by the English researcher Roy Canning. $)^{14}$.

At this point, in our view, the factors of dual education and lifelong learning strategies coincide. And it can be stated that dual education is not only a certain single educational vector in the combination of theory and practice but a formula of successfulness and competitiveness of higher educational establishments, from which everyone benefits, the students already dealing with the real industrial sector, employers, who "lead" their potential employee, coordinating efforts and resources, a university that, to survive must turn into an educational hub, where the efforts of all stakeholders in the education of the parties are accumulated and their routes are built (or synchronized)".

Separately, it is necessary to establish another strategic marker for dual education, which unjustifiably slowly "enters" our domestic higher education establishments, into the "heads" of educational managers and politicians: it implies urgency to take into account tectonic shifts in understanding the essence of education as a social entity (which changed the paradigm of education as an institutionalized space with elements of discipline, influence, control, suspicion). The pragmatism of choice and the factor of expediency of using resources will almost certainly allow the modern young person to voluntarily choose a place of study in which he/she feels uncomfortable, uncomfortable and uninterestingly. That is, a social contract at the university, in each audience, as a mutual responsibility of all stakeholders in the education of the parties, creates a true dialogue of interaction (rather than simulating it as an identity and an ideal that will never be achieved).

It is not necessary to see that the dual principle "cures" our higher education both from diseases of growth, and diseases of inferiority and total lack of funds in the state, in the citizens (in the absence of the middle class the state financing of education and culture is always a total

${ }^{14}$ Canning R. (2012). Re-conceptualising Vocational Education: The Transition from Powerful to Useful Knowledge. The Future of Vocational Education and Training in a Changing World. Springer Fachmedien Wiesbaden GmbH, pp. 43-61. 
saving and scarcity of resources). In the same way, the initiative of educational modulation must come not only from the Universities: the interest of enterprises and entrepreneurs in skilled workers should be based on a legislative framework with clearly spelt out rules of the game in the common field called "education - business". Currently, the dual education forms offered by the line ministry are distributed exclusively within specific government programs, which, rather, create single precedents but do not affect systemic indicators. And this is all against the backdrop of another systemic problem. Now Ukraine is acting rather as a raw material base of human capital The state invests considerable money in all educational units, and at the exit, the best ready specialists go to work abroad (this problem can also be partially solved through a gradual introduction of a dual model of education).

Indicative to understanding the essence of dual education (and not just its formal features) is an example of art education in Ukraine, in which despite all the "reform" is maintained a consistent three-level model of learning. Thus, at every stage, "players" of all levels play an active role, communicating with each other, establishing an established system of "supply and demand" with constant monitoring of the quality of education, the labour market, etc... Music schools or lyceums actively cooperate with art schools, hold competitions, provide qualified advice to teachers and potential entrants; art schools also become a necessary base for teaching, teaching and other professional practice. The same thing happens in the "lyceum" - "universities-academies-conservatories" chain, where the higher educational establishment attracts the best workers and students to form a professional environment for communication and learning with the assessment of the professional level of the student at their educational base or school base (lyceum), with their sector of pedagogical practice and, in the future, await graduates in the status of future student. And most importantly, communication, the dialogue is not lost during the transition from one link to another. Teachers of schools, who have brought up a future specialist of a secondary specialized school or lyceum, are also interested in the continuation of their education in the institutions of the third or fourth levels (most often, the teacher himself was a graduate of this institution in the past).

With this example, we have to prove the need to actualize the domestic experience of "productivity", to take into account all its positive aspects. All the more so as it relates to the cultural and artistic sphere, which is, to a lesser extent, typical and indicative and unambiguous than the sphere of material production, the sphere of services and the like. For example, the German experience in the 
implementation of dual education is not measured in the creative field (all research sections are closed only in the engineering professions, crafts, small and medium-sized businesses). Besides, one should not look for the "best" model of dual education as such; it is necessary, when creating your own, to take into account the goals that are set for education in each situation, based on different visions of the education essence as such: in certain countries, it is, first of all, the economic component, in others - the social or/and political.

Also, the approach to introducing the dual form of education and its various models in higher education institutions should take into account the peculiarities of the university's mission, its traditions, goals and objectives (for example, at KNUC\&A students are formed in the career models of "Success Stories" and the "Talented Entry without Queue" trajectory"). Otherwise, we would receive another, far from reality, tandem, apologizing for the tautology, "impractical" theory and "nontheoretical" practice, which is combined only on paper curricula and educational programs.

In this context, it is more likely to take into account the end -to-end educational strategy (school - lyceum - bachelor's degree's - master's degree's programmes-postgraduate studies), at each stage of realization of which there is an awareness of the following tasks and each stage forms its practical skills that can be implemented at each subsequent stage. For example, at the level of Doctors of Philosophy, Doctors of Arts, the process of bridging the gap between theory and practice, education and production is crystallized within an individual university: often the University itself is not an affiliated customer and stakeholder as an interested party in the preparation of a highly qualified teacher, "grown" from the best students - bachelors, masters). And whether the principle of duality in the mission and tradition of the University is laid, in creating the proper conditions for the formation of an intellectualprofessional, that critically reflects and, keenly sensing the present, always in all situations finds motivation for creativity and selfperfection. University education is also aimed at achieving universal competencies. I. Petrova formulates the relevant opinion on the example of our University's activity: "Thus, the idea about the predominance in the curricula of profile-oriented disciplines is widespread. However, it should be emphasized that the fundamental disciplines of the modern university (in KNUC\&A - Philosophy, Psychology, Sociology, Cultural Studies, Cultural History, Socio-Cultural Management) - is the basis for the formation of not only a professional specialist-practitioner but also a 
foundation for the growth of the future scientist. It is an integral step, the so-called "alphabet" that allows you to form analytical, logical and scientific thinking, revealing the ability to validate and predict results. Later, this ability will come in handy when there is "no answer at the end of the textbook" when the student will be required to think critically and be able to not only adapt to constant change but also to solve real problems, to be able to predict and eliminate their occurrence" ${ }^{\text {"15 }}$.

\section{CONCLUSIONS}

It is important to realize that in Ukraine, with its post-Soviet rudiments (in both good and bad terms), higher education is a social project (almost a national idea for every family). Those newest educational trends and innovative technologies that we try to follow in the examples of European and world universities are embedded in a fundamentally different educational paradigm - the paradigm of education as a social contract with the establishment of an effective dialogue between all stakeholders, the student, the community and the student.

Ukraine is gradually reconfiguring its educational space into a social contractual paradigm, the dual principle of education activates stakeholders, civil society, local territorial communities. Examples of such a shift are the introduction of individual models of dual education and its forms (the article analyzes the positive experience of KNUC\&A), which are mainly aimed at the system of vocational and vocational education. But the true model of education, as a social contract, works for us as a pragmatic combination of the state's educational instruments, research institutions, the private sector of the economy and public organizations, parents, students and all stakeholders in improving the quality of education. And the introduction of the dual education system in higher educational establishments the accelerates the much-needed paradigm transformations, already providing the national educational space with adequate flexibility, speed to respond to socio-cultural and political changes, adaptability, conceptual integrity and strategic expediency. But life is also out of place. Therefore, the dual model is a kind of lever that is convenient to measure very thin, but sensitive to all

${ }^{15}$ Natsionalnyi zvit za rezultatamy mizhnarodnoho doslidzhennia yakosti osvity PISA [National Report on the Results of the International Study on the Quality of Education PISA] (2018). Retrieved from: http://testportal.gov.ua/wpcontent/ uploads/2019/12/PISA_2018_Report_UKR.pdf (accessed 26 January 2020). 
external influences (as a membrane), the intersection - between the present and the steps that should be taken tomorrow (and so on a daily basis). And the practice-oriented strategy has always been a measure of the adequacy of the steps taken, and our realities are no exception.

\section{SUMMARY}

The article has examined the basic parameters of dual education, reveals its specificity on the example of the educational process of the Kyiv National University of Culture and Arts, the positive and negative consequences of its implementation through the prism of world educational experience have been formulated. An in-depth analysis of "duality" in education as a system of combining training and production has been carried out in the light of the experience of Germany, Poland, Austria, Switzerland, Canada, but with an emphasis on their own national realities and unique educational technologies.

The practice of the Kyiv National University of Culture and Arts has been revealed at an angle of stable uniqueness and structural principles of search and selection of "eternal" educational values with a flicker of light irony, originality and non-system. Steps of building curricula and programs based on the principle of "exit" from the audience during the training time, invitations to teaching positions of the best and most successful specialists in different industries project the transition from the classroom to creative workplaces, laboratories, workshops. The main idea of dual education in the modern university is implemented by means of the educational model of educational courses without lecture blocks, and the game model is embodied in the way of students learning results' evaluation.

The introduction of dual education in higher education establishments should encompass the mission of the university, its traditions, goals and objectives so that the combination of theory and practice is not only on the curriculum and educational programs. It is emphasized that it is not necessary to look for the "best" model of dual education but to embody the goals of education in each situation based on different visions of the essence of education: economic, social or political.

\section{REFERENCES}

1. Boichevska I. (2009). Rol systemy dualnoi osvity u profesiinii pidhotovtsi molodi u Nimechchyny [The role of dual education in youth vocational training in Germany]. Porivnialno-pedahohichni studii, no. 2, pp. 68-74. 
2. Callaghan R. (2017). Universities teach soft skills employers want to students of 'hard' disciplines. Financial Review Mar 30. Retrieved from: https://www.afr.com/work-and-careers/education/universitiesteach-soft-skills-employers-want-to-students-of-hard-disciplines20170328-gv89hq (accessed 26 January 2020).

3. Canning R. (2012). Re-conceptualising Vocational Education: The Transition from Powerful to Useful Knowledge. The Future of Vocational Education and Training in a Changing World. Springer Fachmedien Wiesbaden GmbH, pp. 43-61.

4. Hardabkhadze I. (2018). Dualna osvita u feshn-dyzaini: problemy i perspektyvy [Dual education in fashion design: problems and perspectives]. Demiurh: idei, tekhnolohii, perspektyvy dyzainu, no. 1, pp. 59-72.

5. Hlazkova I., Khyzhniak I. (2019). Stanovlennia teoretychnoho ta praktychnoho komponentiv dualnoi systemy osvity $\mathrm{v}$ Nimechchyni [Formation of theoretical and practical components of the dual education system in Germany]. Profesionalizm pedahoha: teoretychni ta metodychni aspekty, no. 9, pp. 70-83.

6. Hrynevych L. Kontseptsiia pidhotovky fakhivtsiv za dualnoiu formoiu zdobuttia osvity [The concept of training specialists in the dual form of education]. Retrieved from: https://btsau.edu.ua/sites/ default/files/Faculties/osvita/dualna/pidgotovki-fakhivtsiv-za-dualnoyuformoyu.pdf (accessed 26 January 2020).

7. Isaacs D. G. (2016). Hard jobs take soft skills. The line report. 2016. May, no. 16. Retrieved from: https://www.lanereport.com/63403/ 2016/05/hard-jobs-take-soft-skills/ (accessed 26 January 2020).

8. Krymchak L. (2019) Systema dualnoi osvity yak umova yakisnoi pidhotovky konkurentospromozhnykh profesionaliv na rynku pratsi $\mathrm{v}$ Ukraini [Dual education system as a condition for qualitative training of competitive professionals in the labour market in Ukraine]. Teoriia ta metodyka profesiinoi osvity, vol. 2, no. 11, pp. 83-86.

9. Natsionalnyi zvit za rezultatamy mizhnarodnoho doslidzhennia yakosti osvity PISA [National Report on the Results of the International Study on the Quality of Education PISA] (2018). Retrieved from: http://testportal.gov.ua/wpcontent/uploads/2019/12/PISA_2018_Report_ UKR.pdf (accessed 26 January 2020).

10.Petrova I. V. (2019) Profesiina pidhotovka ivent-menedzheriv u konteksti dualnoi formy zdobuttia osvity [Training of event managers in the context of dual education]. Visnyk Kyivskoho natsionalnoho 
universytetu kultury i mystetstv. Seriia: Menedzhment sotsiokulturnoi diialnosti, vol. 2, no 1, pp. 82-104.

11.Postoian T. (2015). Dualna systema navchannia v umovakh haluzevoi klasteryzatsii [Dual training system in the conditions of branch clustering] Pedahohichni nauky: teoriia, istoriia, innovatsiini tekhnolohii, no. 2, pp. 374-382.

12. Stoliarchuk I. (2019). Napriamky spivpratsi TsSN "PROKOM" ta ZVO. Dualna osvita yak proiekt yakisnoi pidhotovky IT-fakhivtsiv [Directions of cooperation between CSC „PROCOM” and ZVO. Dual education as a project of qualitative training of IT specialists]. Retrieved from: https://it-universe.org/ua/blog/Konf/Conf2019/9_Напрямки\% 20співпраці\%20ТОВ\%20Проком\%20та\%203ВО.\%20Дуальна\%20осв іта.pdf (accessed 26 January 2020).

13. Svitailo N. Dosvid Nimechchyny v pytanni reformuvannia osvity: dualna osvita [German experience in reforming education: dual education]. Friedrich Ebert Stiftung. Retrieved from: https://www.slideshare.net/ omosvita/ss-62919443/ (accessed 26 January 2020).

14. Yogansson F. (2008). Effekt Medichi: vozniknovenie innovatsiy na styike idey, kontseptsiy $i$ kultur [Medici effect: the emergence of innovation at the intersection of ideas, concepts and cultures]. Moscow: OOO "ID Vilyam S". (in Russian)

\section{Information about the author: Poplavskyi Mykhailo, orcid.org/0000-0002-8234-8064}

Doctor of Pedagogical Sciences, Professor, Kyiv National University of Culture and Arts, 36, Ye. Konovaltsia Str., Kyiv, 01133, Ukraine 


\section{THE CULTURE AT THE BEGINNING OF THE NEW MILLENNIUM FROM THE PERSPECTIVE OF „THE SURVIVOR": A FUNDAMENTAL BREAK IN THE SECRET CODE OF AESTHETICS. UKRAINIAN EXPERIENCE ${ }^{*}$}

\section{Humeniuk Tetiana}

\section{INTRODUCTION}

Global transformations in the modern world are affected by processes that take place in the post-Soviet space because they have formed a unique type of culture, which researchers define as a product of trauma caused by the long internal colonization of the people mentality.

At the turn of the XX - XXI centuries, like other boundary situations in the history of society, the perception of the past is sharpening, and the $\mathrm{XX}$ century, especially its last decades, is perceived as not only the end of the century but of the entire historical epoch, in fact, of all modern times. This situation actualizes the recollections and comparisons with the beginning of new milestones in the history of mankind, especially the views, concepts of famous thinkers, scientists, artists who felt the dynamic of the historical process. It is not about the echo of times, not in a chronological sense. Obviously, in our time it is worth resorting to the verification of some beliefs views, concepts, theories, to compare them with the present reality, because some of them, having flourished, denied, even forgotten, become relevant again. One of these is the concept of catharsis, which was substantiated in ancient aesthetics. It was organically incorporated not only into the scientific circulation but also widely used to characterize the everyday life realities of modern society, influencing the criteria for the evaluation of art. These issues are especially relevant in scientific research with the beginning of the active development of society in the periods of post-: post-industrial, postmodern, post-historical...

\footnotetext{
* "The survivor" - Eng. -“a person who survived", "victim".
} 


\section{1. "Traumatized" as a Symptom of Modern History:}

\section{From the Beginning of the XX to the Beginning of the XXI Centuries}

In the history of Ukraine, in particular, during the $\mathrm{XX}$ and XXI centuries, there were many tragic events that formed the traumatic experience of society: World War I, Civil War, collectivization, deportations, Holodomor 1932-33, Stalinist terror of the 30's and the postwar years, the Second World War, the Famine of 1947, the collapse of the Soviet Union, the Chernobyl disaster, the Maidan, the annexation of the Crimea, the war in the Donbas. It is important to understand the nature of their cultural, social, psychological collective and individual transformations, to develop strategies for working with such experiences, including psycholinguistic ones, in order to further overcome its negative consequences.

The theoretical discourse on historical events that gave rise to collective trauma is one of the elements of the cultural paradigm that articulates this trauma and enables its subject to overcome the effects and consequences of the experience. Besides, it at least draws the attention of the society to the acquired tragic experience, which causes deep social and psychological traumas, requires elaboration and reflection. The lack or insufficiency of appropriate analytics on the causes and effects of such injuries is dangerous because the pain experienced is chronic and transmitted to the next generation. Therefore, it becomes necessary to consider a rather wide range of interdisciplinary studies on the concept of trauma, to analyze the formation of different types of narratives about the collective traumatic experience acquired by Ukrainian society at the beginning of the 21 st century.

The analysis of interdisciplinary studies of the concept of trauma, the involvement of theoretical tools of multi- and interdisciplinary text "trauma studies" provided an opportunity to reveal the essence of different types of narratives about the collective traumatic experience acquired by Ukrainian society at the beginning of the 21 st century. First of all, it should be noted that the word "trauma comes" from the ancient Greek $\tau \rho \alpha \nu \mu \alpha$, that is, "wound", and, according to most researchers, the concept of "trauma", is a paradigmatic characteristic not only of the history and culture of the XXI century but also of the XXI century beginning. Therefore, the sensitivity of society to the topic of violence, theorisation and detailed categorization of these phenomena, or, conversely, the inability to execute it (in cases of extreme violence that destroys any category), only intensify with the deepening of the modern 
traumatic experience of humanity. As political rhetoric becomes more and more biopolitical, a new conceptual paradigm is emerging in relation to the trauma, according to which societies and politics, religion and law, medicine and psychoanalysis, science and the arts can be in new relationships.

The theoretical concept of our study is based on the work of Tamara Hundorova, which emphasizes the need: “... to speak and study the traumatic places of Ukrainian culture of the beginning of the $21 \mathrm{st}$ century - post-colonial ressentiment, the break of generations and the memory of the past in modern post-Soviet times, in the artistic culture in general - T. H.), the break of high and popular culture, a new understanding of the classics, kitschization as a way of reception of traumatic experience, as well as Chornobyl - an event that has largely defined and shaped initial thinking in Ukraine."1 The indisputability of this opinion is confirmed by the unique artistic phenomenon of 2019, which shocked the whole world - the American mini-series about the Chernobyl disaster. This film makes the viewer feel the horror, despair, helplessness, confusion and tragic hopelessness of the people who directly experienced this tragedy. All those involved - politicians, officials, station workers, in a critical state of radiation poisoning, concealed the real state, produced great lies to cover up the terrible scale of the catastrophe.

The film "Chornobyl" is not perceived as an accusation of the Soviet system or a campaign against the use of nuclear energy. It focuses on the trait that is common to all people on their ability to solid lie and that it revolves not only in the scale of geopolitics but also in personal relationships (and it is the most important!). "Chornobyl" touches universal values... This film is not only about Chernobyl but also about us, - Erlingur Einarsson writes in his review of the series. ${ }^{2}$

Socio-psychological scientific studies of world tragedies of this magnitude began in the 1970s, the authors of which focused on these socalled post-traumatic stress disorders. They identified and compared links between the psychological reactions of those who went through the

1 Hundorova T. (2013) Vid avtora [From the author]. Tranzytna kultura. Symptomy postkolonialnoi travmy [Transit culture. Symptoms of postcolonial trauma]. Kyiv: Hrani-T, p. 20.

${ }^{2}$ Einarsson E. (2019, June 06) Chernobyl review: "Stunning and shattering in equal measure". Retrieved from https://www.gamesradar.com/chernobyl-hbo-review/ (accessed: 19.06.2019). 
Vietnam War, who survived the Hiroshima bombing and Nazi torture, survived the Holocaust or slavery and segregation among AfricanAmerican identities. Researchers have developed a new, important category for our time - the survivor: "the one, who survived", "injured», "victim". 3

In particular, Robert Jay Lifton writes in his books about wars, social and environmental disasters, first and foremost as the collision of a person with death. He tries to spread the suffering of the victims to the outside world, because the destructive potential of these disasters means that "we all belong to those who survived after Hiroshima," and let's add: after the Holocaust, after colonialism, after Chernobyl, after the Maidan, after "the war". 4

The prolonged impact of traumatic experiences on the individual and the collective consciousness gives rise to a feeling of fear, a deep inner vulnerability at the individual and collective levels, dividing life into "before" and "after". The theory of national trauma by Arthur Neal ("National trauma and collective memory: major events in the American age") is convincing and important for considering the problem raised, according to which decisive factors for turning any event into a national trauma are its deviation from the "norm", from the usual state of things, radical changes in society that "affect all major subgroups of the population." In this case, the crisis that actualizes national trauma can be acute, caused by an aggressive act or catastrophe, or chronic, prolonged.

These reflections are directly related to the situation in Ukraine. In particular, T. Hundorova notes that Ukrainian society is in a long process of exiting the state of enslavement - political, social, economic, mental. It characterizes the culture of Ukraine as a product of trauma, defining it as transit.

Due to the tragic events of the late twentieth - early twentieth centuries, Ukrainian society is experiencing a state of transition (transit Latin trans name - "through", "across" and the verb "trans+ire" -

${ }^{3}$ Lifton R. (2005) Tehnologija "promyvki mozgov": Psihologija totalitarizma [Brainwashing Technology: The Psychology of Totalitarianism]. St. Petersburg: Prajm-Evroznak.

${ }^{4}$ Lifton R. (2005) Tehnologija "promyvki mozgov": Psihologija totalitarizma [Brainwashing Technology: The Psychology of Totalitarianism]. St. Petersburg: Prajm-Evroznak.

5 Neal A. G. (2005) National Trauma and Collective Memory: Extraordinary Events in the American Experience. Armonk, New York: Routledge, p. 10. 
"pass") into a new being of culture. By the way, the communicative patterns inherent in an individual trauma differ from those which are inherent in a national, collective trauma: If individuals reluctantly transfer negative or disturbing information, then traumatic the event of national scale quickly extends, bearing mass experience as a result of which there is an effect of mutual "attraction": individuals are grouped to have an opportunity to respond to the tragedy in a certain way. Also, if individual reactions to traumatic experiences can be as varied as possible, sometimes even opposite, then “... collective responses are standardized in the process of the formation of myths and legends aimed at defining the moral boundaries of society." 6 .. In this way, we reform society as a moral community and create sacred symbols capable of shaping national identity.

One of the important problems in the process of shaping modern Ukrainian society is the lack of a unifying myth that would direct present contradictory, sometimes tragic, transgressive processes in society. For example, in different regions, social groups acquire a rather arbitrary interpretation of the events of World War II, the Soviet past of Ukraine, the modern movement towards European iteration, and many other phenomena of social life. Such a contradiction is inherent in the Ukrainian mentality, it reflects the state of Ukrainian consciousness, which has been affected by the traumatic processes that determine the present and affect the future of the country.

As a result of the Chornobyl disaster, Ukraine has emerged as a deeply traumatized social space that has signalled to the world a new state: the entry into the zone of a new culture of the humanity of the third millennium. As A. Neal points out: “...trauma often frees up the social system: by shedding the old order, it reveals new opportunities and innovations when the very fact of a subversive event can testify to the ineffectiveness of the social system." Playing this tragedy on-screen made an impression of amazing power - today, Ukraine is perceived in the world as a unique space in which the collective traumatic experience, important to all humanity, as a warning and a caution, is concentrated.

The Chornobyl series drew attention to the problem of "memory recovery". Screenwriter Craig Meisin had collected books about Chornobyl that helped him work on the film. Among them are many

${ }^{6}$ Neal A. G. (2005) National Trauma and Collective Memory: Extraordinary Events in the American Experience. Armonk, New York: Routledge, p. 20. 
Ukrainian editions, including: "Chornobyl: Documentary Story" ("Dnipro", 1989) by Yuri Shcherbak, "Chornobyl Notebook" ("Dnipro", 1990) by Grigory Medvedev, "Outland, or Walk into the Zone" (NoraPrint, 2015) Markiyana Kamysh, "KGB Chornobyl File". (Compiled by SBU Sectoral State Archives, Institute of History of NASU, Ukrainian Institute of National Memory, 2109). It is fundamental for the authors and editors of these books to realize that victims are not only remembered for the past, but are still living this event, so it is always upto-date. "Traumatized ... turn into a symptom of a story that they are unable to fully master.",

Ukrainian society has yet to realize its tragic losses, unite so that the individual does not fall into "...the dead-end of endless melancholy, inability to grieve ..." manifested in the compulsive re-actualization of experience, in the interference of the past in the present and in the present time. Thus, awareness of the tragic experience as a kind of nonhealing "wound" on the cultural fabric of society is important because it has powerful inertia, acquiring the "symbolic expansion" and universalization necessary to understand it. This leads to a disturbance of the world of senses and meanings that continues in the time-space of culture, broadcasting from generation to generation.

Both the word "Holocaust" (in Hebrew "Shoa" - "catastrophe", "disaster") after the show of the same name on American television (1978) and the words "Chernobyl", "Maidan" "war in the Donbas", "annexation of the Crimea" have become a kind of metaphor; they not only express the tragedy of the historical experience of the Ukrainian people but also warn humanity against threats in the way of its further cultural progress. So, not only do we "look" into our past and present, but the whole world takes into account our historical experience. After all, this is the change of world narratives in the context of "transculturalism" at the beginning of the 21 st century, when Ukraine, with its extremely complex and multi-vector social and cultural progress, creates a completely unique, model of national life.

7 Caruth C. (ed.) (1995) Trauma: Explorations in Memory. Baltimore: Johns Hopkins University Press, p. 5.

${ }^{8}$ Alexander J. (2013) The Meanings of Social Life: cultural sociology [Smysly soczialnoj zhizni: kultursocziologiya], (trans. G. K. Olkhovikova). Moscow: Praksis, p. $102-103$. 


\section{Contemporary Art Sub Specie Theory of Catharsis}

In today's medialized world, there is a unique opportunity to "evoke a sense of simultaneity of historical experience", "a sense of empathy with experience" in different peoples, societies and categories of population, enabling a special type of shared, social autobiographical memory of events to be formed ${ }^{9}$.

At the beginning of the new millennium, the cultural memory of humanity is first and foremost actualized. The process, according to French historian Pierre Nora, is truly global, worldwide ${ }^{10}$. It is predicated on specific historical reasons: the first of these is the acceleration of history, which destroys the integrity of historical time, that beautiful and clear straight line that combined the past with the present and the future. The historical disavowal of models of ideas such as restoration, progress, and revolution have made it impossible to foresee the future, forcing the present to remember, too hypertrophying the role of memory, compelling to collect the remnants of the past to overcome its isolation. This is in line with the concept of the British historian Eric Hobsbaum, who believes that modern societies need to restore, "invent" traditions and "connect" them to the common space of the past and present in order to capture at least part of the chaotic social life ${ }^{1 \mathrm{f}}$. The second reason for the seizure of memory is the powerful movement toward the liberation and emancipation of peoples, ethnicities, groups, individuals in the modern world, for whom this is a prerequisite for asserting one's identity and individuality. As Oswald Spengler noted, living a cultural life is a tense, passionate struggle with civilization processes that, by unifying one's personality is killing him: which does not take into account concepts and

9 Olick J. K. (2012) Figuracija pamjati: processo-reljacionnaja metodologija, illjustriruemaja na primere Germanii [Memory Configuration: Process Relational Methodology Illustrated with Germany]. Sociologicheskoe obozrenie [Sociological Review], vol. 11, no. 1, p. 55.

10 Nora P. (2005) Vsemirnoe torzhestvo pamyati [World Celebration of Remembrance]. Pamjat o vojne 60 let spustja: Rossija, Germanija, Evropa [The memory of the war 60 years later: Russia, Germany, Europe]. Moscow: Novoe literaturnoe obozrenie, pp. 391-403.

${ }^{11}$ Hobsbaum Je. (2000) Izobretenie tradicij [Invention of tradition]. Vestnik Evrazii [Bulletin of Eurasia], 1, pp. 47-62. 
systems. The glorious lunge (act $-\mathrm{T}$. H.) is more valuable here than the glorious conclusion" 12 .

Therefore, modern civilization is undergoing a reflection of its past in order to bring back to life those important meanings that lie in the cultural memory of humanity and which are powerfully actualized in a new, post-modern and post-modern space. After all, according to Ananda Kumaraswamy, in the world that modern philosophers dream of, even the names of ancient Greek or medieval treatises are a mystery, and their content comes from a completely different world - a world of tradition that is far from us much more than any astronomical worlds ${ }^{13}$.

Modern scholars have resorted to a new reading of ancient philosophy in accordance with the queries of our time ${ }^{14}$. Today, the awakening of historical memory, the recollection of the past, are key in society. These processes are in stark contrast to the beginning of the twentieth century when particular importance was attached to the future: the focus shifted from the "resent-day", the energy of which nourished the culture of modernity, to the "past present." From the apocalyptic myths of the birth of a "new man" and radical historical ruptures, through the deadly racial and class cleansing of the national-socialist and totalitarian regimes of the last century, there has been a shift, and, rather, an active search for previously "displaced components of the historical process." Today, any radical opposition is rejected for the sake of the possibility of dialogue with the past in the light of the future.

Thanks to the revival of memory, various theories and concepts are actualized as components of the world, in particular, European culture, which throughout its existence needs cultural and phenomenological reflection.

The analysis of contemporary sub specie art (at the point of view) of catharsis theory is complicated by the fact that it is almost impossible to cover all the forms, styles, genres, artistic directions, after all, the personalities that today make up the space of the arts. Therefore, it is

${ }^{12}$ Spengler O. (1993) Zakat Evropy. Ocherki morfologii mirovoj istorii [Sunset of Europe. Essays on the morphology of world history], vol. 1: Geshtalt $i$ dejstvitelnost [Gestalt and reality]. Moscow: Mysl.

13 Coomaraswamy A. K. (2011) Christian and Oriental Philosophy of Art. Mineola: Dover Publications.

${ }^{14}$ Nails D. (2019). Ljudi Platona. Prosopografija Platona i drugih sokratikov [People of Plato. Prosopography of Plato and other abbreviations]. Moscow: Grekolatinskij kabinet Ju. A. Shichalina. 
important to find out how the present and everyday life of societies, communities, and the individual are reflected in the arts and become participants in it. The specificity of the impact of art on humans, as we know, lies in the emotional reactions in the process of perceiving a work of art, and in this way is artistic communication. The highest manifestation of this influence is the phenomenon of catharsis, the interpretation of which is transformed in the context of those changes that take place in art from antiquity to our day.

Despite the fact that the concept of catharsis is common, it is necessary to specify its meaning in modern scientific discourse. As you know, Aristotle applied the theory of catharsis to the analysis of the phenomena of art and their role in society. His definition of the tragedy genre is based on the notion of catharsis as an emotional purification: "Tragedy is an imitation of action, serious and complete, with a certain volume, imitation by the speech adorned in each of its parts differently; by action rather than story that purifies because of pity and fear»» ${ }^{15}$.

What is the relevance of this aesthetic category in the cultural development of the 21 st century? In what ways is catharsis as a way of spiritual healing and healing of man, release from negative emotions, from anxiety, still remains the most important element of sensory culture today? How does catharsis, as the highest manifestation of the influence of art on the emotional sphere of man, transform into a situation "after postmodernism", that is, in the artistic culture of the early 21 st century?

The peculiarities of art development were influenced by the formation of a new sensual cultural type based on the new quality of the art world in the $21 \mathrm{st}$ century. Its characteristic feature is the experience of catharsis - the cleansing of the horrors of the past, which is experiencing the world "after Oswiecim" (T. Adorno). Thanks to the catharsis in the society of the age of "artisation" of everyday life, there is a rise of creative forces of culture. The catharsis of everyday life fits in with the concept of "fluid modernity" by Z. Bauman or a "flexible community" by J. Lipovetsky. It is about the readiness of the current mobile culture to constantly change, the inability to retain specific forms for a long time. The ideas of a prominent British sociologist, philosopher, most fully reflect the state of affairs of a modern society full of fear before the end of the world. This topic is mainstream for both research and works of art of recent years. In trying to answer the question of what the concept of

${ }^{15}$ Aristotel (1967) Poetyka [Poetics], (trans. Ten B.). Kyiv: Mystetstvo, p. 42. 
"end of the world" means and what role an individual plays in society, the scientist emphasizes "individuality" as an important characteristic of being in the culture of the late twentieth and early twentieth centuries.

In recent years, the centre of gravity has been transferred to the individual, who begins to perform those functions and solve those tasks that previously belonged to the sphere of activity of administrative, collective bodies. Along with the processes of globalization on a planetary scale, “... there is a process of "localization", of space fixation. Taken together, these interrelated processes dramatically differentiate the living conditions of populations across entire countries, regions, and diverse segments of the population." ${ }^{\text {"16 }}$ In social life, the principles of pluralism prevail, including the pluralism of cultures, the principles of democracy, and the individualization of subjects. This ensures the compatibility of different value systems, the right to be different. In the field of mobile culture, there is a chance to consume the same cultural products. "The concept of culture as an activity carried out by one part of the population in relation to another is superseded by the concept of a spontaneous process, which has no administrative or management centres, does not obey any master plans" ${ }^{\text {"17 }}$.

While in Kyiv, Z. Bauman participated in the Discussion Platform conference of the First Kyiv Biennale of Contemporary Art's project "Best Times, Worst Times. Renaissance and the Apocalypse in Contemporary Art". In one of his interviews, he drew attention to a situation that has developed in the world culture and is associated with a sense of the end of a certain period, its exhaustion and, at the same time, a lack of a sense of something new. It is the feeling of "empty space" (according to Peter Brooke), the completion of one world and the transition to a new reality, not yet understood, which we face in the form of a diverse continuum of new and new meanings, in which "... the usual

${ }^{16}$ Bauman Z. (2004) Globalizacija. Posledstvija dlja cheloveka i obshhestva [Globalization. Implications for man and society], (trans. Korobochkina M. L.). Moscow: Ves Mir, p. 11.

${ }^{17}$ Badyor D. (2012, April 19) Zigmunt Bauman: "Konets sveta - eto otsutstvie uverennosti v zavtrashnem dne" [Zygmunt Bauman: "The end of the world is a lack of confidence in the future"]. Retrieved from https://lb.ua/culture/2012/04/19/ 146824_zigmunt_bauman_konets_sveta-.html (accessed: 19.01.2019). 
and tried and tested means of effective action are not working already, and new tools and strategies have not yet been developed" 18 .

Reflections on catharsis as a category are directly brought into the realm of the aesthetic, where its history actually takes place. The sphere of contemporary art is a layer of non-classical (post-classical) culture. For the most part, it is not in line with the principle of mimesis, although it is capable of raising topical issues, involving the viewer, the listener, the reader in the dialogue. And here another problem arises because it is not always those who perceive art are ready for such a dialogue. Yes, there are negative reactions due to misunderstanding of "such art". Since aesthetics directly addresses the issues of perception of art, it is interesting to consider the transformations of classical concepts ("aesthetics", "aestheticization", "aesthetic") in connection with changes in art.

The problem of solid consumption, hedonistic personalization, related to the apotheosis of the cult of wish-fulfilment, thirst for entertainment and passive contemplation, which leads to the loss of landmarks, moral guidelines, and ultimately, cultural ethics, attracts the attention of philosophers. Consumer society needs a field of culture today that would be prepared to counter the logic of consumption, which would prevent the "purification", "catharsis" of society, including art for the sake of the future.

This universal approach makes it possible to combine all the arts in the interspecific space of artistic culture, which dominated the historical and philosophical reflections and formed the basis for contemporary cultural and philosophical and aesthetic knowledge. On the phenomenon of catharsis in art, in particular in the art of theatre, they are, in a new sense, conceived by contemporary researcher Kathy Chukhrov. It is important that the term "theatre" in this context does not mean theatre as one of the arts' kind. According to Kathy Chukhrov, the concept of "theatre" means a kind of mechanism, with the help of which we can speak of art as not a real practice. She introduces into the scientific discourse the concept of theatre as an object of art. The artist is not just living life as art, but trying to understand and rethink everything that goes on in life. He or she must have an ability to "live" the life of other

${ }^{18}$ Badyor D. (2012, April 19) Zigmunt Bauman: "Konets sveta - eto otsutstvie uverennosti v zavtrashnem dne" [Zygmunt Bauman: "The end of the world is a lack of confidence in the future"]. Retrieved from https://lb.ua/culture/2012/04/19/ 146824_zigmunt_bauman_konets_sveta-.html (accessed: 19.01.2019). 
people, must be ready to comprehend the universal (social, political, ethical, aesthetic, everyday).

Art, in this sense, is full of potentialities to encompass all available potentialities, which has led to a considerable number of languages of expression - from classical types to performative, collage, installation art. Such openness of art is peculiar to everyone. The introduction of the terms "theatre" and "performance" is connected with the definition of a new situation in art, which " $\ldots$ is somewhat on the verge of conditionally" objective "reality and its transformation. But this transformation is not self-sufficient, not self-reflective, as in modernism, and not total, as, in the classical avant-garde, it is as an event is put into the world and passes through a person, placing his or her life between being and over-being"19.

Here it is appropriate to turn to the ideas of Susan Sontag, an American researcher, the legislator of "radical fashion". In her work Against Interpretation, she argues that the culture of our time is characterized by a loss of ability to sense-perception, it is generated by excessive desires and overproduction, that interpretation is a revenge on the intellect of art, a manifestation of stifling reactivity, timidity, stagnation. For her more sensual vision, perception, sensation, in her opinion, it is necessary to give up hermeneutization and move to "eroticization of $\operatorname{art}{ }^{20}$. She believes that art is not obliged to be read as a text, because works of art are not just about telling something, commenting on something, arguing or denying it - they are already something. Art should evoke an experience, a sense of presence, a state of certain enchantment.

The problem of the new "erotica of art" resonates with the very topical theme of "outsidering", "otherwise", as the catharsis of everyday life experienced by a person "from there", becoming in the everyday life of society an object of humiliation, humiliation, and partly - violence. How lonely a person feels, which does not fit into the usual relationships of people in society, goes to the art of the era of "colour", "gender" and more. In her essay, Pornographic Imagination (1967), S. Sontag writes

${ }^{19}$ Chuhrov K. (2011) Byt i ispolnjat. Proekt teatra $v$ filosofskoj kritike iskusstva [To be and to fulfill. Theater project in philosophical criticism of art]. St. Petersburg: Izdatelstvo Evropeyskogo universiteta v Sankt-Peterburge, p. 30.

20 Sontag S. (2006) Proty interpretatsii [Against interpretation]. Proty interpretatsii ta inshi ese [Against interpretation and other essays], (trans. Dmytruk V.). Lviv: Kalvariia, pp. 10-21. 
about the need for the human being to "go beyond its borders," "to overcome one's personality," in particular, about the state of the artist in a world of non-classical (post-classical) culture: "As a free explorer of dangers, overbearing, the artist is entitled to differ in his behaviour from the majority, given the peculiarities of the vocation, he may, for example, be distinguished by an eccentric lifestyle, or may not. His real business the trophies of experience, objects and deeds that can ignite and enthral, and not only (as the former concepts have been attributed to the artist) to teach and have fun. It ignites, as a rule, one: a step into the dialectic of the disorder. He wants to do things disgusting, dark, incomprehensible, in a word - something that doesn't like (or doesn't like). But no matter how cruel the extremes of the artist impress his audience, his credentials and spiritual authority ultimately depend on the real or possible sensitivity of the public to those extremes, which he is trying himself..."21. The author is convinced that art draws from diverse human experience, including one based on various modes of personal transcendence. This "extended scale of experience" is an extraordinary power beyond good and evil, it is a test of catharsis beyond the mind.

At the same time, Dr Jennifer Wallace, a professor at Cambridge University, points out that the media and the public respond to tragic events, as the authors of a Greek tragedy do: instead of feeling horrified, they told about it as well as about tragic events. Therefore, in her opinion, the experience of catharsis is now more problematic. After all, according to Aristotle, the events depicted in the tragedy help to purify or ease the internal state of the viewer. That is, tragedy plays a certain moral function in society. Is it possible in modern life?"22 D. Wallace adds: "In an era of round-the-clock news and constant potential contact with tragedies around the world through the Internet, it may be paradoxically difficult to focus on the suffering that playwrights may have experienced and reproduced in the past. Does this even matter to us

${ }^{21}$ Sontag S. (1997) Pornographic imagination [Pornograficheskoe voobrazhenie]. Mysl kak strast. Izbrannye esse 1960-70-h godov [Thought is like passion. Selected essays of the 1960-70s], (ed. Dubina B., trans. Golysheva V.). Moscow: Russkoe fenomenologicheskoe obshhestvo, pp. 8-18.

22 Rozwadowski J. (2012, May 09) Reinventing tragedy in the modern age. Retrieved from https://www.cam.ac.uk/research/news/reinventing-tragedy-in-themodern-age (accessed: 19.01.2019). 
today? Is it the ability to create what can be called a "good tragedy", a sign of human civilization or a sign of a humane society?",23

Sinclair, professor of Contemporary Spanish Literature and Intellectual History, explains the over-interest of contemporary media in tragedies of other people, the transformation of information about disasters into everyday life by the fact that the line between awe and the horror that we often cross is too thin. "I am amazed that we take these stories on a daily basis. They cannot be considered catharsis, but constantly perceiving them is important to raise questions about our experience in general and our experience, which is difficult to face"24. She notes that Spanish writers of the twentieth century, including Federico Garcia Lorca, faced the need to reinvent tragedy for contemporary audiences, seeking to reconcile elements of Greek tragedy with contemporary realities, but perhaps avoiding catharsis. Moreover, many theorized in the early twentieth century that a new form was needed to replace tragedy. The goal, in her opinion, was to interrupt the processes of identification and/or catharsis, to release the viewer or even make him not feel, but to think about what was happening on stage, as well as the consequences of what he saw for himself.

The main difference in the aesthetic perception of classical and contemporary art lies in the fact that classical art is full of images and modern - ideas. T. Binkley considers the description to be used as a basic aid for understanding contemporary art by means of which one can access an idea conceived by the author of a work ${ }^{25}$. The author takes a controversial stance on aesthetics as a science. Her work, written in 1997, is actualized today as a revival of interest in the art of the 90s, with its "grassroots" aesthetics that began to acquire rights and emerge from the shadow of "outsider", "abnormal", "unacceptable".

${ }^{23}$ Rozwadowski J. (2012, May 09) Reinventing tragedy in the modern age. Retrieved from https://www.cam.ac.uk/research/news/reinventing-tragedy-in-themodern-age (accessed: 19.01.2019).

${ }^{24}$ Rozwadowski J. (2012, May 09) Reinventing tragedy in the modern age. Retrieved from https://www.cam.ac.uk/research/news/reinventing-tragedy-in-themodern-age (accessed: 19.01.2019).

${ }^{25}$ Binkli T. (1997) Protiv Jestetiki [Against Aesthetics]. Amerikanskaya filosofiya iskusstva. Osnovnye kontseptsii vtoroy poloviny XX veka - antiessentsializm, pertseptualizm, institutsionalizm [American Philosophy of Art. Basic Concepts of the Second Half of the 20th Century: Anti-Essentialism, Perceptualism, Institutionalism], (eds. Dzemidok B., Orlov B.). Ekaterinburg: Delovaja kniga. 
Creative events at the Arsenal of Art are full of similar meaning ("Flashback. Ukrainian Media Art of the 1990s", 2018), at PinchukArtCenter ("Red Book: Soviet Art of Lviv of the 1980s and 1990s" , 2018) and more. In particular, perhaps the most significant event in 2019 was the presentation of Olha Petrova's book "Art Kyiv in the 1990s: Reconstruction" held at the Khanenko Museum. As the researcher, philosopher, well-known artist, noted in her interview, the 90s was an extraordinary period in the history of Ukrainian art, when a talented galaxy of artists emerged who "... adopted a system of rebellion against everything, embraced voluntarism, nature of which I understand because it was contained in the socio-political climate of the time. Therefore, in the book, I describe the workshop art on a broad sociopolitical background, which is the interest of this work. After all, the 90s was a period of tough, though in some places invisible struggle between the old system, which did not want to leave, and the new one, which was not yet formed $\gg$.

In particular, T. Binkley, as the author of the work Against Aesthetics, does not support the view that aesthetics should be necessarily and primarily related to the philosophy of art. The term "aesthetics", coined by A. Baumgarten in the sense of "the science of perception", distinguished between aesthetic and abstract entities, that is, things that are sensually perceived and those that are perceived by the mind. T. Binkley, according to Kant, distinguishes the perception of aesthetic qualities not only concerning art but much more broadly - to human activity in general, in all its riches. Thus, for aesthetics, not only art objects are objects of study, but also aesthetic experiences and experiences in a wide variety of daily life areas.

Considering the impossibility of identifying the object of aesthetics and the object of art, T. Binkley characterizes contemporary art: "It liberates itself from aesthetic parameters and sometimes creates directly through ideas not mediated by aesthetic qualities. A work of art is a creation, and creation need not be an aesthetic object or even an object at

26 Andriivskyi uzviz svoho chasu buv ukrainskym Monmartrom dlia khudozhnykiv - Olha Petrova pro mystetstvo 90-kh rokiv [Andriyivsky Uzviz was once a Ukrainian Montmartre for artists - Olga Petrova on 90s art]. (2019, November 20). Retrieved from ukr.radio/news.html?newsID=91710 (accessed: 20.11.2019). 
all» ${ }^{27}$. So, we can say that contemporary art no longer exists in the classical dimension of the aesthetic, and therefore should not cause aesthetic experiences in the audience. Of course, the time during which art underwent a dramatic change and ceased to conform to the classical canons of mimesis is very short compared to the era when it developed according to classical mimetic principles. Only since the beginning of the twentieth century and until today it has undergone profound changes in the sphere of the aesthetic, in the perception of works of art (modern, post-modern, post-post-modern or contemporary...) and their evaluation and interpretation. The question here is how and in what way the classical idea of catharsis was transformed in the context of understanding the "tragic" today.

At the beginning of the twentieth century, Jean Baudrillard noted in the book Transparency of Evil that the boundaries of the aesthetic expanded significantly, encompassing all spheres of life: “... freeing from forms, lines, colours and aesthetic concepts, blending all cultures and all styles, our society has achieved universal aestheticization, all forms of culture ..." aesthetics. Accordingly, the experience of catharsis from communication with actual artistic creativity is complicated by philosophy, constant reflection of art about itself, because it requires intellectuallyinterpretative work, theorizing, and most importantly, a certain sensual detachment.

Due to the proliferation of performative, corporeal forms, contemporary art becomes too shocking, it is not capable of making a strong emotional impression, leading to catharsis, in its classical sense. Moreover, in the opinion of the philosopher, the use of traditional aesthetic concepts is generally ambiguous, and even inappropriate, because nowadays the only aesthetic canons by which the works of art can be compared and evaluated have been lost. Indeed, the aesthetic categories, which since antiquity had been the indestructible criteria in

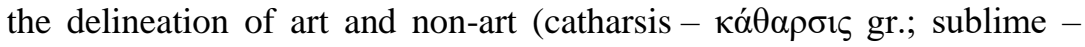

${ }^{27}$ Binkli T. (1997) Protiv Jestetiki [Against Aesthetics]. Amerikanskaya filosofiya iskusstva. Osnovnye kontseptsii vtoroy poloviny XX veka - antiessentsializm, pertseptualizm, institutsionalizm [American Philosophy of Art. Basic Concepts of the Second Half of the 20th Century: Anti-Essentialism, Perceptualism, Institutionalism], (eds. Dzemidok B., Orlov B.). Ekaterinburg: Delovaja kniga.

28 Baudrillard J. (2000) Prozrachnost zla [Transparency of evil], (trans. Ljubarskaja L., Markovskaja E.). Moscow: Dobrosvet. 


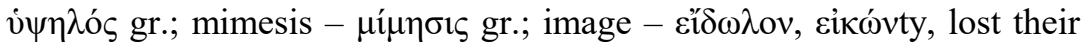
primary significance. Gradually the main feature of culture was the total aestheticization of the world, "even the most corrupt and obscene" (Bordriyar) acquires aesthetic features, embedded in the artistic sphere, becomes a cultural object.

Researchers point out that in the art of the XX - the beginning of the XXI centuries famous artists with their works consciously contributed to the fundamental break of the secret code of aesthetics. According to J. Ranier, the true aesthetic revolution can be considered the willingness of artists to show and glorify anyone and anything: "Such a phantasmagoric dimension of the true, belonging to the aesthetic mode of art, played an important role in the establishment of the critical paradigm of humanitarian humanities" 29 .

Touching on the topic of breaking the secret code of aesthetics, let us give the opinion of Dietmar Kamper, a sociologist, anthropologist, philosopher, one of the representatives of post-structuralist thought in Germany: "The only work of modern civilization was the constant production of artificiality, and therefore, aestheticization; modern culture is becoming a commodity that is unacceptable because art must be internally contradictory and not reproduce the consumer system. Only a person can choose the only possible option to move away, dissociate from the system and start to act proactively due to their virtuosity, not virtuality"30. For Kamper to be responsible means the ability and willingness for the artist at the moment of the highest danger to put himself at stake, raising a fundamental question for him.

The theme of catharsis as a warning and prevention of recurrence of the tragedy prompts us to return to our reflections on those events that determine our present and affect the future not only of our country but of the whole world. Thus, the TV movie "Chornobyl", according to IMDB, is recognized as the most popular series of all time (!), It provokes discussions, provokes passionate reactions. Nowadays tourists and journalists are eager to visit the exclusion zone. However, these tragic

${ }^{29}$ Rancière J. (2007) Razdeljaja chuvstvennoe [Sharing the sensual], (trans. Lapickij V., Shestakov A.). St. Petersburg: Izdatelstvo Evropeyskogo universiteta v Sankt-Peterburge.

30 Kamper D. (2010) Dvulikij Yanus media E`stetizacziya dejstvitel nosti. Vozmushenie chuvstv [Two-faced Janus Media. Aesthetization of reality. Outrage]. Telo. Nasilie. Bol [Body. Violence. Pain], (trans. Savchuk V.). St. Petersburg: Russkaja hristianskaja gumanitarnaja akademija, pp. 55-57. 
events have not only catastrophic man-made consequences - no less an ontological shock has emerged: a new ecology of culture has emerged, which contains a discourse on the collective trauma of humankind living after the "touch of death".

Recognizing that any analogy is rather conditional, let us recall in this context the fire that took place in April 2019 in the Cathedral of Notre Dame de Paris. It is known that in 1831 Victor Hugo wrote this novel of the same name to draw public attention to a landmark of national architecture that suffered so much during the Great French Revolution that it could be lost forever. But the publication of the novel, in the preface to which Hugo wrote, "One of my main goals is to inspire the nation with a love of our architecture," prompted the public to rebuild the cathedral. In the aftermath of the 2019 fire, culture, art, France and the world took on such a mission, apart from the media and the Internet.

In this way, trauma is closely linked to the problem of truth or what is called the "crisis of truth", thus raising the question: how can we have access to our historical experience today? Therefore, there is no one-sizefits-all approach to listening, listening to traumatic experiences, and stories about it. Their exclusivity requires a wide variety of reflections in psychoanalytic and psycholinguistics, in philosophy and cultural studies, in political science and history, as well as in the arts in general. The need for complex reflection is generated by the originality of the event itself as an exceptional, tragic experience that goes beyond human understanding.

Ukrainian art (nota bene! - here inevitable parallels with the novel of the French classic) draws attention to Ukraine, its history and contemporary problems due to the artistic reproduction of the Chernobyl tragedy (other tragedies in modern and post-modern history) in its "nonidentity". The means of art reveal a rigorous, uncompromising understanding of the phenomena and events that Ukraine is experiencing, entering a new, post-imperial, post-Soviet phase of its history. Society is painfully undergoing a long process of escaping the captivity of centuries-old colonization of mentality. The new generation of Ukrainian artists is creating a modern national space, full of socio-cultural reflection, aimed at reflecting on "one's" and "other's", centre and periphery, dominant and subordinate, individual and social, monomulticultural, authentic and globalized, certifying the culture state of the third millennium: the entry into the world of "sub specie".

Since the Chernobyl catastrophe, so many significant historical events and socio-cultural shifts have taken place in Ukraine that it is now 
possible to speak of a completely different reality than that associated with the end of the twentieth century as the time of the fall of totalitarian regimes

The processes experienced by Ukrainian society since the end of 2013 make it possible to speak about their collective character since they have caused tectonic shifts in the recent history of Ukraine: Revolution of Dignity, execution of Maidan participants, subsequently - annexation of Crimea, military aggression in the Donbas, proclamation of DNR and LNR (The Donetsk People's Republic and the Luhansk People's Republic) an economic and political crisis that triggered a new cultural upheaval, manifested in the will of the people in the 2019 presidential and parliamentary elections. What is rather polemical, with pain, aware of the difficult political experience of the Maidan, the Ukrainian historian A. Plachonin called it as the end of the "era of self-pity"

The uniqueness of T. Hundorova's study "Transit Culture", mentioned by us, is that despite its transient and extremely rapid sociopolitical and cultural changes, her ideas do not become obsolete, but become even more relevant, contribute to the understanding of the situation in which Ukraine found itself. Maidan and the long conflict in the Donbas. Particularly valuable for understanding the current Ukrainian reality are the researcher's remarks on "resentment" as a factor in the formation of post-colonial and post-totalitarian social (subjective) consciousness. Despite the literal meaning of the term (French ressentiment - outrage, indignation), it is more complex and contradictory in its meaning. The phenomenon of resentment arises in a situation of extreme tension between a sense of self-esteem and, at the same time, a hatred of all the enemy, which is perceived as the cause and source of damage, loss, powerlessness, and ultimately, inferiority. Such a condition, as the researcher points out, "... is the critical instance where effect takes the form of resentment. The discharge leads either to pathology or turns into a complex but productive cultural therapy" ${ }^{\text {, }}$. That is the experience of catharsis, we will add.

Taking into account the events that Ukrainian society is experiencing today, the experience of the Maidan fits into the much broader context of post-communist trauma, moreover, into the discursive field of trauma

31 Hundorova T. (2013) Vid avtora [From the author]. Tranzytna kultura. Symptomy postkolonialnoi travmy [Transit culture. Symptoms of postcolonial trauma]. Kyiv: Hrani-T. 
studies, which for most researchers is a paradigm characteristic of the late twentieth and early twentieth centuries' culture. Thus, modern researchers emphasize the importance of "discourses" - the "testimonies" of all those who survived, suffered, or fell victim to "see" and "hear" the tragedy. It is from the moment of the written-proclaimed testimony, whether it belongs to an individual or a group of people, or takes the form of a work of art, that society begins to work with the consequences of its traumatic experience. Therefore, the concept of "traumatic character of culture" is expanding to the whole world, especially modern researchers emphasize sensitivity to the topic of violence of non-western parts of the world, in which the most catastrophic events are happening in recent times.

It turns out that Ukraine's experience from the Maidan to the annexation of Crimea and the war on Donbas is consonant with world history of the beginning of the 21st century. It highlights the threatening conflicts in the new era of humanity already. Moreover, in the socialized world, there is a unique opportunity to evoke the feeling of historical experience simultaneity in different nations, societies and categories of people, a feeling of empathy that will form a special type of shared social memory.

Turning to 2019, it should be noted that for the Ukrainian society after surviving the Maidans, after the last presidential election, probably the most characteristic is the "next morning syndrome". In the history of Ukraine, the problem of trust and mutual understanding between citizens becomes actual again, that is, the opportunity arises to profess common values as the basis of community culture and identity. Social ambivalence, as a simultaneous commitment of people to opposing, sometimes incompatible values, characterizes a transitional society.

The long shadow of the past and, at the same time, the irreversibility of the historic progress towards freedom, are the poles of tension that determine the path to the formation of a renewed Ukrainian nation, they will contribute to the unification of the west and the east, the north and the south, past and present Ukraine. According to the apt statement of the Ukrainian cultural scientist and political scientist Taras Wozniak, it is the tragic events of recent years that present the reality of the present, with the help of which the cathartic experience we can look into our future.

Another factor of dependence and inability to forget is the incredible strain of the spirit, the fascinating atmosphere of the significance of what is happening because this is what has become, for many, the "top of life". In general, it is the state of any "excessive" or grieving subject who 
is unable to overcome the melancholy dependency on survived experience or love. Exactly these poles of worldview tragically combined in time and space two superfluous personalities, two talented artists - Vasily Spivak, an opera singer who left his successful creative life in Paris to fight and die for Ukraine, and Leonid Kanter, the coauthor of the documentary about him - "Myth". This name is short for Mephistopheles, this is the call sign of the hero - a reference to the favourite character of the singer from the opera "Faust". The director Leonid Kanter, in collaboration with I. Yasny, avoided frank mythmaking, favouring moving thoughts about V. Slipak, the nature of victims and wars in general. It is a philosophical, deeply humanistic and multifaceted message about a maximalist personality. "The Myth" begins and ends with Parisian children listening to their teacher in the classroom, who is reading a book by Gianni Rodari. Gelsomino, with his charming voice, which people could not help overhear, was able to save the Land of Liars by expelling the autocrat ruler. Vasily Slipak was killed, but Ukraine has not yet been rescued. His voice continues to be heard, he is heard ... However, life is carrying out its tragic recursion: there is a war in Donbas, there is a confrontation between politicians, parties, people ... Meanwhile, in the personally built art-khutor (so to speak, in the other, already Ukrainian "Neverland") Leonid Kanter at the age of 36 , committed suicide...

"Listening", attentive listening to one's historical experience and the history of it, about their exceptionality requires a multifaceted response, complex thinking, including artistic. Since the experience tests the limits of our understanding.

Taking into account the consequences of the tragic events in the history of Ukraine that took place during the end of the XX - beginning of the XXI centuries, relying on interdisciplinary studies of the concept of trauma, on different types of narratives about collective trauma the experience gained by Ukrainian society at the beginning of the 21 st century it is possible to claim that they had a significant impact on the cultural processes of modern times. This gave an opportunity to show the development of Ukrainian culture of this period as a reflection of the deep traumatic processes that determine not only its present but also affect the cultural progress of mankind. The symbolic extension and correlation of the Ukrainian people experience with the world transgressive processes universalizes it as one that is essential for global understanding in the world, which is possible only if one is able and willing to listen and hear. 


\section{CONCLUSIONS}

Therefore, the main purpose of contemporary art today is to "raise questions", problems that are important but not articulated in everyday life. Thus, the categories of the aesthetic force to analyze the sociocultural logic of development of modern society. After all, the art which we can consider relevant, effective, seeks to reproduce, replicate social, focusing on problems in modern society. Thanks to this reflection, the identification of the individual and the society in a particular cultural type occurs. As a theatre is a mediator between the event and the individual, so the culture becomes the mediator between the history and the individual, the history and the society. It fills us with what we could not naturally obtain. In experiencing this fullness, there is a selfpromotion of a society to a new cultural form. It can be argued that every nation, every society from time to time undergoes the revival of its culture, tests the cultural genes that have shaped its uniqueness, reflected in the uniqueness of its centuries-old fate. A non-reflective society is doomed to degradation.

\section{SUMMARY}

The section describes a wide range of interdisciplinary studies on the concept of trauma and includes a theoretical toolkit for multi- and interdisciplinary trauma studies to analyze different types of narratives about collective traumatic experiences acquired by Ukrainian society in the early 21 st century. The sensitivity of society to the topic of violence, its theorization and detailed categorization, or vice versa - the rejection of this in cases of extreme violence that destroys any category, increase with the deepening of the modern tragic experience of humanity. The prolonged impact of traumatic experiences on the individual, as well as on the collective consciousness, gives rise to feelings of fear and vulnerability at the individual and collective levels. As a result of the Chernobyl disaster, Ukraine emerged as a deeply traumatized social space that signalled to the world about a new state: entering the zone of a new culture of the humanity of the third millennium.

At the beginning of the new millennium, the cultural memory of humankind is actualized. Today, the awakening of historical memory and the recollection of the past are key in society's life. This contrasts sharply with the beginning of the twentieth century when particular importance was attached to the future: the focus shifted from the "present to present", the energy of which was nourished by the culture of modernity, to the "past present." The specificity of the art impact on a 
person is emotional reactions in the process of perceiving a work of art, and in this way is artistic communication. The highest manifestation of this influence is the phenomenon of catharsis, the interpretation of which is transformed in the context of those changes that take place in art from antiquity to our day. The peculiarities of art development were influenced by the formation of a new sensual cultural type based on the new quality of the art world in the 21 st century. Its characteristic feature is the experience of catharsis as a "purification" of the horrors of the past.

\section{REFERENCES}

1. Alexander J. (2013) The Meanings of Social Life: cultural sociology [Smysly soczialnoj zhizni: kultursocziologiya], (trans. G. K. Olkhovikova). Moscow: Praksis. (in Russian)

2. Andriivskyi uzviz svoho chasu buv ukrainskym Monmartrom dlia khudozhnykiv - Olha Petrova pro mystetstvo 90-kh rokiv [Andriyivsky Uzviz was once a Ukrainian Montmartre for artists - Olga Petrova on 90s art]. (2019, November 20). Retrieved from ukr.radio/news.html? newsID=91710 (accessed: 20.11 .2019$)$.

3. Aristotel (1967) Poetyka [Poetics], (trans. Ten B.). Kyiv: Mystetstvo. (in Ukrainian)

4. Badyor D. (2012, April 19) Zigmunt Bauman: "Konets sveta - eto otsutstvie uverennosti v zavtrashnem dne" [Zygmunt Bauman: "The end of the world is a lack of confidence in the future"]. Retrieved from https://lb.ua/culture/2012/04/19/146824_zigmunt_bauman_konets_sveta.html (accessed: 19.01.2019).

5. Baudrillard J. (2000) Prozrachnost zla [Transparency of evil], (trans. Ljubarskaja L., Markovskaja E.). Moscow: Dobrosvet. (in Russian)

6. Bauman Z. (2004) Globalizacija. Posledstvija dlja cheloveka $i$ obshhestva [Globalization. Implications for man and society], (trans. Korobochkina M. L.). Moscow: Ves Mir. (in Russian)

7. Binkli T. (1997) Protiv Jestetiki [Against Aesthetics]. Amerikanskaya filosofiya iskusstva. Osnovnye kontseptsii vtoroy poloviny XX veka - antiessentsializm, pertseptualizm, institutsionalizm [American Philosophy of Art. Basic Concepts of the Second Half of the 20th Century: Anti-Essentialism, Perceptualism, Institutionalism], (eds. Dzemidok B., Orlov B.). Ekaterinburg: Delovaja kniga.

8. Caruth C. (ed.) (1995) Trauma: Explorations in Memory. Baltimore: Johns Hopkins University Press. (in English) 
9. Chuhrov K. (2011) Byt $i$ ispolnjat. Proekt teatra $v$ filosofskoj kritike iskusstva [To be and to fulfill. Theater project in philosophical criticism of art]. St. Petersburg: Izdatelstvo Evropeyskogo universiteta v Sankt-Peterburge. (in Russian)

10. Coomaraswamy A. K. (2011) Christian and Oriental Philosophy of Art. Mineola: Dover Publications. (in English)

11. Einarsson E. (2019, June 06) Chernobyl review: "Stunning and shattering in equal measure". Retrieved from https://www.gamesradar.com/chernobyl-hbo-review/ (accessed: 19.06.2019).

12. Hobsbaum Je. (2000) Izobretenie tradicij [Invention of tradition]. Vestnik Evrazii [Bulletin of Eurasia], 1, pp. 47-62.

13. Hundorova T. (2013) Vid avtora [From the author]. Tranzytna kultura. Symptomy postkolonialnoi travmy [Transit culture. Symptoms of postcolonial trauma]. Kyiv: Hrani-T.

14. Kamper D. (2010) Dvulikij Yanus media E`stetizacziya dejstvitel'nosti. Vozmushhenie chuvstv [Two-faced Janus Media. Aesthetization of reality. Outrage]. Telo. Nasilie. Bol [Body. Violence. Pain], (trans. Savchuk V.). St. Petersburg: Russkaja hristianskaja gumanitarnaja akademija, pp. 55-57.

15. Lifton R. (2005) Tehnologija „promyvki Mozgov”: Psihologija totalitarizma [Brainwashing Technology: The Psychology of Totalitarianism]. St. Petersburg: Prajm-Evroznak. (in Russian)

16. Luckhurst R. (2008) The Trauma Question. New York: Routledge. (in English)

17. Nails D. (2019). Ljudi Platona. Prosopografija Platona i drugih sokratikov [People of Plato. Prosopography of Plato and other abbreviations]. Moscow: Greko-latinskij kabinet Ju. A. Shichalina. (in Russian)

18. Neal A. G. (2005) National Trauma and Collective Memory: Extraordinary Events in the American Experience. Armonk, New York: Routledge. (in English)

19. Nora P. (2005) Vsemirnoe torzhestvo pamyati [World Celebration of Remembrance]. Pamjat o vojne 60 let spustja: Rossija, Germanija, Evropa [The memory of the war 60 years later: Russia, Germany, Europe]. Moscow: Novoe literaturnoe obozrenie, pp. 391-403.

20. Olick J. K. (2012) Figuracija pamjati: processo-reljacionnaja metodologija, illjustriruemaja na primere Germanii [Memory Configuration: Process Relational Methodology Illustrated with 
Germany]. Sociologicheskoe obozrenie [Sociological Review], vol. 11, no. 1, pp. 40-74.

21. Rancière J. (2007) Razdeljaja chuvstvennoe [Sharing the sensual], (trans. Lapickij V., Shestakov A.). St. Petersburg: Izdatelstvo Evropeyskogo universiteta v Sankt-Peterburge. (in Russian)

22. Rozwadowski J. (2012, May 09) Reinventing tragedy in the modern age. Retrieved from https://www.cam.ac.uk/research/news/ reinventing-tragedy-in-the-modern-age (accessed: 19.01.2019).

23. Sontag S. (1997) Pornographic imagination [Pornograficheskoe voobrazhenie]. Mysl kak strast. Izbrannye esse 1960-70-h godov [Thought is like passion. Selected essays of the 1960-70s], (ed. Dubina B., trans. Golysheva V.). Moscow: Russkoe fenomenologicheskoe obshhestvo, pp. 8-18.

24. Sontag S. (2006) Proty interpretatsii [Against interpretation]. Proty interpretatsii ta inshi ese [Against interpretation and other essays], (trans. Dmytruk V.). Lviv: Kalvariia, pp. 10-21.

25. Spengler O. (1993) Zakat Evropy. Ocherki morfologii mirovoj istorii [Sunset of Europe. Essays on the morphology of world history], vol. 1: Geshtalt i dejstvitelnost [Gestalt and reality]. Moscow: Mysl. (in Russian)

Information about the author: Humeniuk Tetiana, orcid.org/0000-0001-9210-6424 Doctor of Philosophy, Professor Kyiv National University of Culture and Arts 36, Ye. Konovaltsia Str., Kyiv, 01133, Ukraine 
DOI https://doi.org/10.36059/978-966-397-197-1/49-67

\section{INFORMATION AND ADVERTISING DISCOURSE AS A PHENOMENON OF CULTURE}

\section{Horban Yurii}

\section{INTRODUCTION}

Advertising becomes one of the aesthetic and cultural dimensions of the everyday life's culture, is closely embedded in mass culture, acquires an extremely sharp artistic impulse of the expressive type, and in this dimension becomes a separate, independent form of art with a huge budget, a large impact on the mass. Therefore, in the mass culture it has a special place, and in the post-Soviet culture advertising, on the one hand, helps to exist more effectively such media as television, show business, variety, and on the other becomes political advertising.

Television came later, and the poster discourse in the early periods of television was not as developed as it is now. By itself, advertising becomes not only the carrier of business strategies that exist now in the space of art-business, variety, show-business. Advertising was an element of propaganda and was equal to propaganda discourse. The post-totalitarian space that emerged during the rebuilding era needs more democratic advertising. Advertising messages take signs of performance type, theatricalize, become more serial, form advertising presentations. Typologically, this manifests itself in the fact that advertising is differentiated by genre characteristics: outdoor advertising, advertising in transport, advertising verbal type, advertising on radio, television, advertising as inserts in informational messages, works of art, in particular in television. This first caused shock then got used to the inserts and it turned out that this type of advertising discourse is the most effective. The commercialization and widespread press of advertising space shows that advertising is not just a "trade engine»", it is a certain regulator of mass culture, of the culture of everyday life as such.

The culture becomes impregnated advertising so much that teens begin to sing the slogans, advertising songs are included in the children's life. Advertising discourse grows so much in consumer fibre that it acts as a certain norm of cultural consumption. Without advertising, we no longer think of our existence. We promote ourselves, we become 
subjects of advertising discourse, we see no other role in communication than presentational-gaming.

\section{Social Advertising: Mechanisms of Impact}

Advertising is extremely diverse in ideology, presentation styles, and propaganda values. Under its influence, the worldview of people can become unsystematic, contradictory. For these reasons, advertising is seen as an important factor in the formation of morals, lifestyles and behaviours of children and young people who do not have the experience to critical comprehension of information. Advertising acts as a mechanism of persuasion and influence, and this influence has both positive and negative aspects. It creates false, unnecessary or harmful needs, directs the person to meet psychophysiological needs, increase prestige, but indirectly diminishes the significance of satisfying spiritual, intellectual needs, the role of intangible values. ${ }^{1}$

It is necessary to start the specification of information and advertising technologies in the most topical advertising discourse - social advertisement. It is social advertising that is more free in terms of the artistic potential of the advertising image. The goal-setting effect of advertising as a certain socio-pragmatics is the most dynamic system of the advertising message. However, the very name "social advertising" has not yet acquired a final definition. Any advertising is social, but when it comes to social advertising, it is, above all, advertising that disturbs, exposes social woes, phenomena, personifies them, if they need to be personalized. Or, on the contrary, in a certain person all the troubles of society are found and also an alternative way of changing the path of development, both society and personality is found.

Social advertising is the most dramatic about the conflict of objection and call for the attachment to certain values that are absolutely essential to everyone. The degrees of freedom of disposition and challenge are characterized in such a way as to achieve the greatest degree of contrast. That is, the subject of social advertising is not only a social individual, as is sometimes considered, not a society in a particular problem field but the human race as a whole. Namely, it is the horizon, the actor and the

${ }^{1}$ Hrabchak O. V. (2015) Sotsialna reklama ta yii rol u protsesakh samorehuliatsii suspilstva [Social advertising and its role in the processes of self-regulation of society]. Zbirnyk naukovykh prats Kamianets-Podilskoho natsionalnoho universytetu imeni Ivana Ohiienka. Seriia: Sotsialno-pedahohichna, vol. 24, pp. 44-52. 
actant of social action. The act of social advertising is defined in the general discourse, where the rules and regulations for resolving the crisis are universal. But there is a paradox: the genus does not act. It does not even contemplate. Genus is a limiting abstraction of a person or ancestor, who lives in real time and space, behaves in a particular environment.

The carrier of text in social advertising is a social information of a special type, attributable features of which are: publicistic style, publicity and promotion. ${ }^{2}$ This is the meaning of the text's presentation, which is formally an advertising message and meets the criteria of advertising, and substantially meets the criteria of publicistic style. A sign such as publicity for social advertising text is variable. Its manifestation means explication of the initiating subject of advertising activity, which is not always characteristic of social and advertising discourse. The publicistic style of the information presented in the text of a social media advertisement means an urgency explaining social problems. In this sense, the text of social media advertising is conceived as one of the mechanisms for constructing social problems. The problem category becomes a constant in the social-advertising discourse.

O. Melnyk states: "Advertising of information presented in the text of display social advertising is understood as the ability to pass representative information through the basic modules of advertising influence: segmentation, positioning, image, branding. Therefore, the name of the brand implicitly manifested in the text's structure of display social advertising and, accordingly poorly implemented in the process of the influence of such basic module as branding becomes necessary to reconsider the role, which grows in the process of promotion of socially significant ideas, positions and image of the social object advertised, which in this case perform compensatory function". ${ }^{3}$ The latter statement is extremely important. Brand as a trademark, as a guarantee of quality, does not play a leading role in social advertising. Any subject of the

${ }^{2}$ Melnik O. A. (2010) Sotcialnaia reklama: sposoby predstavleniia sotcialnoi informatcii [Social advertising: ways of presenting social information]. Proceedings of the Zhurnalistika: vzaimodeistvie nauki i praktiki (Russia, Rostov-na-Donu, 2010). Rostov-na-Donu, pp. 168-176.

${ }^{3}$ Melnik O. (2010) Tekst sotcialnoi reklamy v SMI: sposoby modelirovaniia informatcii [The text of social advertising in the media: ways of modelling information] (Abstract of $\mathrm{PhD}$ Dissertation). Voronezh: Voronezhskii gosudarstvennyi universitet. 
discourse is already a generic entity. And so the problem of branding disappears by itself.

That is, we can say that the manifestation of contemporary social problems is defined as a contrastive disposition, where good and evil are polarized. And, in fact, the very nomination of social advertising falls into the circle of similar nominations: social propaganda, sociallyoriented advertising, socially-responsive advertising, non-commercial advertising, public advertising, social-advertising discourse, etc. Therefore, all this, we will say, the nominative forbearance of social and advertising discourse only emphasizes its uncertainty. Therefore, the broad scope of the definition of the category "social advertising" in itself testifies only to the fact that society here acts as a mask, as a metaphor for a completely different issue. The person in the society, the person outside the society, the person as a generic being who fits in and does not fit into the society, produces an ideological complex of social advertising, which is religious in essence. "Religare" is a linking of people, the linking to the absolute - to the absolute good that eliminates metaphysical evil, exposes metaphysical guilt or conversely lifts it to the pedestal. These are the mechanisms that implicitly work in social advertising

It can be said that most of those who study social advertising consider it either in terms of sociological roles and functions, or political concepts, sometimes say that social advertising is connected with the fact that in culture it imitates folklore, archaic consciousness etc. The main thing is that social advertising as a mechanism of suggestion, influence has a clear journalistic direction (i.e. focused on the public) with its clearly defined syntagmatic (spatial articulation), which forces the design of social advertising to concentrate their messages, bring them to the aphoristic boundaries of self-determination. The extremes of the advertising message (verbal, visual) are in contact, and the transgression of all boundaries indicates that for all the phenomenological implications of the advertising image that determine the social problem, there is another phenomenon - a harmonious, self-sufficient image of a man.

Therefore, this type of advertising is not popular. It is rather marginal, but its marginality indicates that it needs more attention than the advertising of goods and services, where the problem of segmentation, positioning, branding is already sufficiently solved, and the strategy of integrated marketing communications overcomes the situation of goods' promotion in the market. In social advertising, there is no promotion of goods on the market. There is a need to treat social ulcers. Thus, the 
manifestation of social issues, its actualization in terms of imaginative realities, moreover, the visualization and aggressive definition of the problem in verbal discourse makes it possible to sharpen realities that are counterfactual. That is, to deny the destructive reality at the level of the metaphysical deep foundations of its origin and to offer not radical treatments, but radical ones, which give the possibility that one will be different. That is, an institutional-discursive approach, when such an institution, as social advertising, has its discourse, requires the definition of a certain ideal model of communication, formed by this advertising. The text of the discourse of social advertising has its communicative specificity, its semiotic reality, which presents and manifests social problems and shapes the needs of the target audience in search of information about their means of elimination or transformation into another problem which can be overcome.

The verbal-visual markers of social advertising are insufficient to make sense of social advertising as a whole. These are just phenomenological signs. Behind them, there is the polymodality of the image, the absolute of the ideal, the absoluteness of life and the denial of death, the denial of the disease, degradation, stagnation. One of the most important principles of the discourse of social advertising is the contrast, the juxtaposition of the two components as a dialogical counterfactual reality. Most often they are death and life, illness and a healthy way of life, degradation and development, disharmony and harmony. They correspond to the desired ideal categories: life, health, success, ideal, harmony, etc. If these categories remain at the level of abstract juxtaposition, they do not solve anything. We need to find a form of communicative presentations, a manifestation of a social problem, which becomes a sort of harmonization manifestation as a phenomenon (artefact) of eliminating a problem, and transforming it into another problem that can be overcome because it is not so dramatic as to require such intense attention.

Therefore, the problem of social advertising dispositions lies not so much in binaries, oppositions of positions, but in seeking dispositions as a system of contradictions, but reconciliation by intensifying a social problem, which in the verbal-visual context of social advertising discourse is defined as the semantic continuum of the radical elimination of evil. Instead of being associated with "nothingness" (the antithesis of beingness), an image of creation emerges, transforming nothing into a true, holistic being of a man. This is always the utopian path. It more often leads to visioning, suggestion. Sometimes this path in the artistic 
dimension becomes a romantic manifestation of the author's selfrealization, but social advertising always actualizes creativity, actualizes the need to be human. Social advertising does not flatten corners, smooth them, do not suppress the problem, and, on the contrary, exacerbates. It tries to find a positive solution from any negativity.

K.-O. Apel, a communications systems theorist, states: "The possibility of such an understanding of criteria, models, standards of correct decision in all human situations implies that speech understanding in every possible language game is a priori linked with the rules which can be established not by the way of "convention" but conversely, make the convention possible. These meta-rules of all conventionally established rules belong, in my opinion, not to certain language games or life-forms, but to a transcendental language game, or to an unrestricted communicative community". ${ }^{4}$ This is a good example that suggests that language consensus is mediated by the consensus of the communicators' arrangements.

In social advertising, we have not just a verification of certain meanings of life, but an event. That is, the figurative reality of the problematized being presented on a certain stage. Problematized on the stage of the problem, on the stage of society, on the stage of figurative reality, above all. And here it is important to apply the category "act". Everyone who participates in discourse becomes actants. That is, they stipulate this act. They become actors, the leaders of its temporality. The act of presenting a problem can be a one-off, solve all problems in a moment. But it can eliminate them in the future and never resolve. The range of temporalities from one moment to eternity, from the solution and not the solution of the problem at all - this is the distance in which the dispositive of the discourse of social advertising is formed. This dispositive is not a concern for itself, according to M. Foucault, it is not a problem of thinking about a purposeful-rational solution. It is rather aesthetic, visionary, mystical. Thus, sometimes something that has the prerequisite for consensus or some kind of agreement at the level of imaginative representations and imaginative abilities of the advertising message's actor becomes able to solve problems, to be the carrier of an eternal, holistic human being.

4 Yermolenko A. M. (1999) Komunikatyvna praktychna filosofiia [Communicative practical philosophy]. Kyiv: Líbra, p. 31. 
K.-O. Apel raises the problem of ethics, the responsibility of humanity as a whole in a state of ecological crises, the threat of nuclear war, tries to put forward certain tenets of responsibility Homo sapiens, which gives the opportunity to reconstruct or construct certain communicative actions. ${ }^{5}$ That is, it is new rationality of ethics of information and communication messages, where the normative conditions are argued from the point of view of the universal. But the general, one way or another, implies a rational statement. It can be said that such rationalization of the universal is, of course, modern construction and, in the context of postmodern consciousness, does not work, or becomes another construct, another postulate of the communicative ethos. However, from the point of view of the one who models this ideal, it is very important for the comprehension of the contextual and communicative act, which is based on the rationality and universal attitude of the person to the world. It is an out-of-contract, that is, transcendental (ideal - in the thesaurus of German practical philosophy) is a real ingredient of communication that precedes any consensus, by any rational, irrational, any other solution, which are possible in one or another society.

A. Yermolenko writes: "Modern western social science and philosophy, exploring the phenomena of "late" capitalism in terms of "social pathology", "anomie", "unmanageable complexity", "lack of legitimation", are trying to look for ways to overcome the social crisis. Their concepts seek to open up new forms of social integration, reconciling personal and public interests, individual and common goals and values. Many Westerners, including German philosophers and sociologists in the last third of the twentieth century, have put forward new paradigms of philosophical and sociological theory. One such paradigm, after "being" and "consciousness," is a communication paradigm that relies on transcendental (ideal) speech pragmatics, defining one of the most influential trends in modern Western thought communicative philosophy". 6

There is a certain linguistic-hermeneutic, pragmatic turn. We can say that this is enough for the ideal model of social advertising to acquire its

${ }^{5}$ Apel K.-O. (1999) Situatsiia liudyny yak etychna problema [Human situation as an ethical problem]. Yermolenko A. M. Komunikatyvna praktychna filosofiia [Communicative practical philosophy]. Kyiv: Líbra, pp. 231-255.

6 Yermolenko A. M. (1999) Komunikatyvna praktychna filosofiia [Communicative practical philosophy]. Kyiv: Líbra, p. 19. 
general features. On the basis of perfect (transcendental) pragmatics, communication based on speech actions or events, in our case consensus of verbal and visual in advertising image, it is possible to define a certain model that can be described as a given imperative for solving the problem, where from the position of the generic subject constants for solving social problems are given. But they are not solved "here" and "now" and are eliminated in the perspective of figurative decisions and proposals.

Advertising in terms of humanization of communication acts as a contextual and content method of person's inclusion into the environment. So D. Smith gives an elaborate phenomenology of advertising discourse: "For the first time, a person looks at an advertising message and does not see it.

For the second time, he or she doesn't notice him either.

For the third time, he or she is aware of his presence.

Fourth, it is hard to remember where he or she saw it.

For the fifth time, he or she reads the ad.

For the sixth time, he or she captures this message with the eyes among other messages.

For the seventh time he reads it all over and says, "Oh, my God!"

For the eighth time he proclaims, "Well, this damn product again!"

The 9th time she thinks, "What is this thing?"

For the tenth time he or she thinks to ask her neighbor if he has bought such a thing.

For the eleventh time, he wonders how this thing can generate advertising revenue.

For the twelfth time, he concludes that this thing is probably worth something.

For the thirteenth time, he concludes that he may need this thing.

For the fourteenth time, he remembers dreaming about this thing all her life.

For the fifteenth time, he is in a hurry that he cannot afford to buy this thing.

For the sixteenth time, he tells himself, "The time will come - and I will definitely buy myself this thing."

For the seventeenth time, he plans to buy this thing.

For the eighteenth time, he curses his impoverishment.

For the nineteenth time, he counts his money. 
For the twentieth time, he again sees ads and buys this thing, or orders his wife to buy it". ${ }^{7}$

When creating social advertising, it's important to consider the age and social characteristics of your target audience. If the recipients of social advertising are youth, it is important that the source of distribution must be the Internet (including social networks) and less - television. Information promotions of social advertising should be directed not only to the object of influence but also to its environment. Rational social advertising should include information about the harmful effects of alcohol, tobacco or drugs on the human body, as well as the difficulties encountered in addiction, problems that can potentially arise in various areas of life. Emotional social advertising is more influential when using positive motivation while stimulating a sense of responsibility and obligation. It is especially important to use short-term inclusion of emotional advertising in rational advertising in order to increase the recipient's attention. ${ }^{8}$

\section{Advertising as a Means of Promotion and Regulator of Mass Culture}

Social advertising has genetically grown out of propaganda. Advertising in a totalitarian culture was not possible; its role was played by a propaganda discourse that was consistent with the mythologeme of an ideally developed society. "It has got better to live, it has become to live more fun" - this brand can be seen in various modifications: in a poster, a picture of Plastov, where the farmers gathered in the field for breakfast with a poster hung over the table with a well-known formula of life. Cheerful from their work people did not notice that they live in a concentration camp, did not notice that it was one more another step and you would stay there forever. Even H. Shchedrovytskyi, a philosopher who gave many theories of design and business games, wrote that when they were young, they did not notice the tragedy of the time, and if somebody was taken into paddy wagons, then they deserved it. The youth danced, everyone went to visit, walked in the

${ }^{7}$ Muzykant V. L. (1998) Teoriia i praktika sovremennoi reklamy [Theory and practice of modern advertising] (Pt. 1). Moskow: Evraziiskii region, p. 39.

${ }^{8}$ Gasiuk M. (2019) Sotsialna reklama yak zasib profilaktyky adyktyvnoi povedinky osib yunatskoho viku [Social advertising as a means of preventing adolescent addictive behavior]. Visnyk Prykarpatskoho universytetu, vol. 22, pp. 67-76. 
evening, all night, and did not even see all that then was told to everyone everywhere.

The advertising world has adequate connotations. In general, advertising as a way of identity is extremely archaic. K. Salnikova, who studied the motives of identification in advertising, writes that advertising is primarily about appealing to the organic senses, to food, sex, enjoyment in general and perceives any event of purchase, acquisition or event of consumption of values in the form of advertising discourse as a certain sublime device, like the world of heroization any consumption.

O. Salnikova writes: "Advertising constantly encourages the use of products, to consume them in all substantial, essential forms. This is a general excitement for advertising. The direct implementation of the excitatory vector into action is the motive of eating. In the advertising plots, any food topic is natural, the absorption of the product is alleged without residue, in its pure form, in the truest sense, that is, absorption as such. <....> The beauties and the handsome of all stripes eat, covering their eyes and almost ecstatic. The grand plans, lit by the delight of faces, are interspersed with the oversized plans of erotic moving lips. Characters of other roles, especially commoners and commoners, eat "deliciously" and joyfully, with moderate and excessive physiological optimism. Families eat in harmonious minor or major, perfectly amicable. Food is a pleasure that is accessible to all. And so food is "unity," a deliciousness that unites all potential audiences from birth to food. People with different looks, gender, age, social status, character, profession, intelligence - they are all equally created to eat something".

However, it is important to note that advertising as a hidden mode of propaganda of the Stalin era was in fact such, it was a heroized ethos of consumption, but the subject of this consumption was necessarily a Soviet worker, in Brezhnev's propaganda discourse he became a winner of the communist winner. Actually, then, there were heroes of labour, unlike the heroes that had existed before, as military figures, winners in the war. That is, the discourse of heroizing reality was not always purely political. It was aesthetic, had its advertising connotations. Advertising as a form of art was heroic propaganda, most often in poster discourse.

${ }^{9}$ Salnikova E. V. (2001) Estetika reklamy. Kulturnye korni i leitmotivy [Aesthetics of advertising. Cultural roots and keynotes]. Moskow: Aleteiiam, pp. 17-18. 
The radio also carried advertising, but not as clearly and clearly as the posters did.

J. Baudrillard states: "The cruelty and sometimes the brutality of the use of advertising technologies are no longer adequate. In this sense, violence and nonviolence, like all antinomic phenomena, play the role of neglect in a society that wants to see itself and sees itself as hyperactive and contented with rockers, on the one hand, and hippies, on the other, are revealed, for example, in their profound characteristics as a society passivity and violence. They take over the hidden violence of this society to turn it against it, deepening it to paroxysm. Others deepen the latent passivity behind the façade of society's additivity, deepening it to the practices of rejection and complete individuality, forcing it thus to deny itself in its relations with its own logic". 10

Advertising sells time, the political electorate, goods as an image, as a person, sells a flash image of a fashionable dress that is dressed to one or another figure of an advertising communicator. There is always an effect of identity totalizing, which is done simply by "pinching" things, by "eating" an advertising image. Haptic eating, the search effect of the deepest identification systems simplifies the communicative discourse and homogenises it. The homogeneity of advertising is so well defined that it even crosses the line between male and female. Advertising becomes androgynous. Androgynism of advertising further universalizes information transmission systems. This is especially felt in the postSoviet space: a purely feminine type of attraction, glamour does not work, because a person is in a difficult position, she can not buy everything.

The male impulse of willpower impulse in advertising is reduced because society suffers from new political fights, new rich people, millionaires, so there is androgynism in one or another genre dimension, in one or another figurative flash image, which presents either male or female in the hypostasis of the consumption's subject. Therefore, advertising should not be regarded as a service, as an auxiliary phenomenon. Advertising becomes a total discourse of communication. Why is this happening?

10 Bodriiiar Zh. (2006) Obshchestvo potrebleniia. Ego mify i struktury [Consumption society. Its myths and structures] (Trans. Samarskaia E. A.). Moskow: Respublika; Kulturnaia revoliutciia, p. 228. 
The need for political advertising is extraordinary, because it plays political games, is carried out in the mask of political carnivals. Political advertising presents the discourse of power, though it is oriented towards humane and social role definitions of actions and image of a person in society. Ye. Romat states: "It should be noted that political advertising is an extremely important but not the main tool of this system. With a wide variety of means of power struggle, advertising plays a whole ancillary role, due to its specific responsibilities, the political market is one of the few areas where the importance and effectiveness of advertising are inferior to public relations (political relations) even in countries with developed democracies, rather than marketing tools, but above all administrative resources, are quite effective".

The genealogy of advertising discourse as a dynamic, expressive and aesthetic reality has several intentions: to "override" others, which is carried out by the complaint - to deny the information that exists nearby; rejection is the first axiom of advertising; this is an extremely urgent use of politics; in fact, it has the natural function of "overlapping" all other media of advertising discourse, that is, those who carry out messages, articulate verbal information. Then, when the screaming effect has already been reached, it is important to keep the information at the level of the perception threshold so that it does not tire, produce a certain context of interest, not be too intentional.

If such a problem did not exist in the age of totalitarianism, advertising as an enclave of propaganda was elementary, there was no question of its authenticity, then in the post-Soviet space, the first of the main tasks of advertising is the need to be relevant. Advertising is always focused on replacing the subject with a flash image, a brand, a trend. Thus, the perfect item is always advertised. However, the function of advertising is not to make a buyer or other thing or service, it is merely an incentive to buy.

These aspects of the information field became extremely polyphonic in the post-Soviet space. The genres of advertising are polarizing, and there is a demand for social advertising: drug addiction, alcohol, depression, disbelief require not only treatment of the targeted client, but also certain measures of special intervention in the soul of the person. Political advertising is breaking all records. The worthy poster with Hroysman's "I am Ukrainian" is an oxymoron, but at the time it looked

${ }^{11}$ Romat E. V. (2008) Reklama [Advertising] (7 ed). St. Petersburg: Piter, p. 144. 
authentic because there was a peculiar presentation of national politics as a broad political identity that went beyond ethnic morality. As time goes by, the policies change and the posters of recent times seem rather naive.

N. Luman notes: "The translation of the selection results is determined in the strict sense of the word, that selective achievement is reproduced in simplified, abstracted from initial constellations conditions. Such simplification and abstraction require symbols that replace the specific foundations of the original context in the breeding chain, so communicative tools evolve into symbolically generalized codes for the purpose of general orientation. Each of the subsequent phases of the process remains therefore in the selection to the same extent as the previous one. The means of communication thus combine the commonality of orientation and the identity of selection. Power as a communicative means functions only under these conditions". 12

The communicative advertising space is becoming more and more indicative of the poetics of postmodern art, including such broad relationships as land art, which is followed by an advertising campaign about red, green, and blue rocks. On the one hand, it is the definition of industrial markers of nature, and on the other, it is the advertising of paints. Also involved are performance advertising stunts, where advertising turns into a particular myth design.

Advertising becomes one of the aesthetic and cultural dimensions of the culture of everyday life and is closely integrated into mass culture. Advertising begins to work in the realm of protest simulators, including putting up non-profit political posters in unauthorized places, production areas of the product runs counter to the advertising discourse in general, but by contrast, it updates its attention. The media and advertising activity becomes extremely aggressive, which immediately offends the recipient. There is a need to humanize advertising messages, to create certain communicative ethics of advertising. P. Ricker writes: "Speech violence should not only be regarded as a formal truth but also spoken of as the imperative of the commandment not to kill at any time, even when it cannot be fulfilled. The one who keeps this commandment always recognizes the other as a reasonable being and in every way respects him". 13

\footnotetext{
${ }^{12}$ Luman N. (2001) Vlast [Power]. Moskow: Praksis, p. 17.

${ }^{13}$ Riker P. (1995) Navkolo polityky [Around politics]. Kyiv: „D. L.”, p. 146.
} 
The role of PR companies in advertising cannot be overlooked. It defines the areas of external and internal communication. F. Sharkov, A. Rodionov note: "External communications combine the organization with the outside world, while internal ones determine the specificity and quality of the organization's activity. The internal relationship is the creation of the image of the leader, the image of the organization and team, including corporate identity, creation of corporate culture (team, work, creativity, life, the system of interaction, personnel issues). External communications are the maintenance of constant contacts with partners, including potential ones, communication with the media, communication with the public society, and government institutions, the actualization of international relations, advertising, preparation for crisis situation and liquidation of crisis". ${ }^{14}$

We can point to certain strategies that are implemented in the advertising culture as effective mechanisms for presenting and communicating information. Thus, this is a balance of presentation and management. Kh. Kaftandzhyiev defines codes for the presentation of information: "The codes of sign systems are a system of rules by which we use signs when we create and perceive messages.

They are mainly rules of alphabetic, semantics, syntax and programming.

The alphabet code is a system of rules by which we structure the alphabets of sign systems. Semantic code is a system of rules by which we structure and express meaning.

The syntax is a system of rules by which we combine characters into texts.

The pragmatic code is a system of rules that help to use the signs depending on the relevant communication situation". ${ }^{15}$

The means of communication are changing, but the communicativesemiotic context remains the same. A balanced presentation also plays a significant role in the integration of advertising technology, as equipment prices go down, it is easy to imagine a time when the walls of the exposition will consist entirely of digital panels. However, traditional

${ }^{14}$ Sharkov F. I. (2007) Reklama i sviazi s obshchestvennostiu: kommunikativnaia $i$ integrativnaia sushchnost kampanii [Advertising and public relations: the communicative and integrative nature of campaigns]. Moskow: Akademicheskii Proekt; Ekaterinburg: Delovaia kniga, pp. 164-165.

${ }^{15}$ Kaftandzhiev Kh. (2006) Garmoniia v reklamnoi kommunikatcii [Harmony in advertising communication] (Trans. Kirova S.). Moskow: EKSMO, p. 34. 
materials and demonstrations will continue to be used to create a balance of information and communication opportunities for information presentation.

The last important aspect of advertising is management, technological maintenance of media technology, where content can be quickly transformed from the most modern means of imagination to the most routine. It is important to program these changes as specific cyclical fluctuations in the advertising space, using the ability to eliminate obsolete items, not to mention regular updating of positioning systems. That is, the information field is exposed, but it can be said that these problems belong to the culture as a whole. Each of the identified areas of the promotional presentation performs a specific function based on its own tasks. After all, the temporality of information presentation, the focus on not stagnating the information every day, was a place oriented to clear codes of its transmission, and at the same time figuratively effective and attractive - this is the supremacy of all cultural advertising practices.

Therefore, advertising brings to its culture its own distinctive locus. Advertising is focused on the collapsed expressive image presentation of the image, unfolds it in infinity (social advertising), focused on the balanced presentation of information (sociopragmatics of advertising messages), which tries to complain (criticize) all other information messages, to consolidate its own image. Advertising performs a real mediating function of the imaginative construction (verbal, visual, pictorial, subject). Actually, the information construction as a pattern, the gestalt of the advertising message characterizes the unity of all certain aspects, their cultural and historical integrity.

Which of the three identified areas of advertising is dominant in the post-Soviet space? There is no clear answer to this question. Since it is not rhetorical, it can be argued that the systemogenesis of the culture of the post-Soviet space activates one or another component in one or another period of integration or vice versa. So now, in the context of the war between Russia and Ukraine, advertising is dominated by the worst meaning of propaganda discourse, everything that is advertised is advertised, but not what can be defined as the deep fundamental values of the modernity's human.

This advertising is closer to passion-advertising, advertising as a system of manipulative technologies of consciousness. If in retrospect, look at the times of perestroika, there was dominant advertising as a broad stream of formation of the desired identity, transformation and presentation of Western images. If we look a little further in retrospect to 
the "fracture" of consciousness (perestroika), then the psychological type of communicative technologies, which formed the guidelines of the nonconform worldview of the 60s, which is still returning today, dominated here. It returns as a concern, but returns already in completely different overtones, other figurative installations. Postmodern identity in the communicative space is formed in completely unexpected circumstances of total play and irony, falling into the field of wide fluctuations in identity, where the recipient is simultaneously a player, consumer, tourist, walker, according to Z. Bauman.

If we use the metaphor of $\mathrm{Z}$. Bauman of tourism as a certain type of sociocultural identity, it is worth pointing that in the age of globalization it is already total, global tourism as consumption of values in a limited time range. Advertising as a type of identity, in the face of globality also falls into the model space of "global tourism". Thus, the consumer of advertising discourse moves the globe quickly, at all airports he is met by a standard set of fast service - coffee, sandwich, juices. Advertisements of all resorts are full of blue sky and yellow sand.

That is, global tourism, as a certain echo of the levelling of culture and suggestion of consumption patterns characteristic of one area, the socalled highly developed countries, copy other cultures, in the reality of advertising messages, focus on the totalization and homogenization of tastes. The consumer model as a "global tourist" is tourism with unlimited advertising opportunities, where an extensive exhibitor indicates that advertising in the age of globalization finds the limits and horizons of local satisfaction of the needs of the selected, and the intensive component indicates that this type of consumption of cultural values, by all means, tries to avoid homogenization.

It seeks to fill in the gaps that globalization of culture as its unification carries out. That is, the yellow sand and blue sky are lit by the cultural space of slogans, flash images that give the aura of another being to natural destinations (attractive landscapes). Global tourism as a type of cultural identity is the reality of consumption of the compensatory type, which can be framed within the so-called metamodernity - wide fluctuations between the extremes of cultural formation.

\section{CONCLUSIONS}

Culture of information and advertising presentations as a kind of art is defined in the ontological realities, which were formed institutionally in the environment space, subject world. So, as an advertisement focused on the environment, transport, the reality with which a person meets every day, ontologically concentrated in the material indirect or re- 
introduction of all other audial, visual, symbolic, iconic forms of communication to the code of a thing, substance mediated is the deepest intuition of advertising social action. Thus, a thing, a symbol, a sign, an image present an ontology of advertising messages as a humandimensional space, a reality that has artistic features. The art of advertising is defined as the ability to convey information, the skill to determine its priority, and as creativity - to involve the creative realities of the identity of the individual and the subject of advertising discourse.

Therefore, a broader integrative locus, mechanism of cultural formation, should be identified than cultural practices, including advertising. In our view, such a broad integrative mechanism is virtual reality in all its connotations, all modes of its presentation, systems of functioning and self-determination of man as a being in the space of virtus of modern culture. Thus virtus man has no mortal form of existence. Consumer man receives the guarantor of immortality with the purchase of a product or service. In essence, it is an archaic code of cultural creation - the elimination of death, but it is not brought to the surface, because this archetype is mercilessly corrupted in the context of modern socio-pragmatic communication. Immortality of the kind Man appears in portraits - in the faces of people who have already reached it. The cyborg warriors, victims of catastrophes, legendary artists, and singers combine in one broad channel of information flow every day and every night of the culture of everyday life, where advertising plays the role of director, arranger and seductive image.

All the above facts make it possible to say that the culture of information and promotional presentations tries to absorb the cultural tradition, on the one hand, and gives the opportunity to escape from the brutal, primitive reality of complaint, the same politics, the need to survive, to compete for life, etc. The whole complex is ontologically immersed in ethics and aesthetics. It can also be noted that advertising has a reduced aesthetic reality, in particular, "tragic" as an aesthetic category in it is almost undefined. We will not see the tragic videos in the commercial, they are more focused on the comic than the tragic.

\section{SUMMARY}

Modern cultural, social and economic processes create the conditions for the existence of advertising space in a new quality, namely as a global axiological translator, which in turn forms a new anthropological type of person, embracing certain traits caused by the peculiarities of modern consumer society. The purpose of the article is investigating the features of the advertising discourse functioning; determining the 
dominant sphere of advertising in the post-Soviet space. The scientific novelty is determined by the fact that the study broadens and deepens the idea of advertising as a phenomenon of culture, demonstrating the importance of a comprehensive study of cultural, anthropological and philosophical aspects of advertising. Conclusions. The art of advertising is defined as the ability to convey information, the skill to determine its priority, and as creativity to tap into the creative realities of the identity of the individual and the subject of advertising discourse. So, as advertising, which is focused on the environment, the transport, the reality with which a person meets every day, is focused on substantially mediating or translating all other audio, visual, symbolic, symbolic forms of communication into a code of things, real-world mediation is the deepest intuition of social actions of advertising. Thus, a thing, a symbol, a sign, an image present an ontology of advertising messages as a human-dimensional space, a reality that has artistic features. All the above facts make it possible to say that the culture of information and promotional presentations tries to absorb the cultural tradition, on the one hand, and on the other gives an opportunity to escape from the brutal, primitive reality of reclamation.

\section{REFERENCES}

1. Apel K.-O. (1999) Situatsiia liudyny yak etychna problema [Human situation as an ethical problem]. Yermolenko A. M. Komunikatyvna praktychna filosofiia [Communicative practical philosophy]. Kyiv: Libra, pp. 231-255.

2. Bodriiiar Zh. (2006) Obshchestvo potrebleniia. Ego mify $i$ struktury [Consumption society. Its myths and structures] (Trans. Samarskaia E. A.). Moskow: Respublika; Kulturnaia revoliutciia. (in Russian)

3. Gasiuk M. (2019) Sotsialna reklama yak zasib profilaktyky adyktyvnoi povedinky osib yunatskoho viku [Social advertising as a means of preventing adolescent addictive behavior]. Visnyk Prykarpatskoho universytetu, vol. 22, pp. 67-76.

4. Hrabchak O. V. (2015) Sotsialna reklama ta yii rol u protsesakh samorehuliatsii suspilstva [Social advertising and its role in the processes of self-regulation of society]. Zbirnyk naukovykh prats KamianetsPodilskoho natsionalnoho universytetu imeni Ivana Ohiienka. Seriia: Sotsialno-pedahohichna, vol. 24, pp. 44-52.

5. Kaftandzhiev Kh. (2006) Garmoniia v reklamnoi kommunikatcii [Harmony in advertising communication] (Trans. Kirova S.). Moskow: EKSMO. (in Russian) 
6. Luman N. (2001) Vlast [Power]. Moskow: Praksis. (in Russian)

7. Melnik O. (2010) Tekst sotcialnoi reklamy v SMI: sposoby modelirovaniia informatcii [The text of social advertising in the media: ways of modelling information] (Abstract of $\mathrm{PhD}$ Dissertation). Voronezh: Voronezhskii gosudarstvennyi universitet.

8. Melnik O. A. (2010) Sotcialnaia reklama: sposoby predstavleniia sotcialnoi informatcii [Social advertising: ways of presenting social information]. Proceedings of the Zhurnalistika: vzaimodeistvie nauki $i$ praktiki (Russia, Rostov-na-Donu, 2010). Rostov-na-Donu, pp. 168-176.

9. Muzykant V. L. (1998) Teoriia i praktika sovremennoi reklamy [Theory and practice of modern advertising] (Pt. 1). Moskow: Evraziiskii region. (in Russian)

10. Riker P. (1995) Navkolo polityky [Around politics]. Kyiv: „D. L.”. (in Ukrainian)

11. Romat E. V. (2008) Reklama [Advertising] (7 ed). St. Petersburg: Piter. (in Russian)

12. Salnikova E. (2012) Fenomen vizualnogo. Ot drevnikh istokov $k$ nachalu XXI veka [The phenomenon of the visual. From ancient sources to the beginning of the XXI century]. Moskow: Progress-Traditciia. (in Russian)

13. Salnikova E. V. (2001) Estetika reklamy. Kulturnye korni $i$ leitmotivy [Aesthetics of advertising. Cultural roots and keynotes]. Moskow: Aleteiia. (in Russian)

14. Sharkov F. I. (2007) Reklama $i$ sviazi s obshchestvennostiu: kommunikativnaia $i$ integrativnaia sushchnost kampanii [Advertising and public relations: the communicative and integrative nature of campaigns]. Moskow: Akademicheskii Proekt; Ekaterinburg: Delovaia kniga. (in Russian)

15. Yermolenko A. M. (1999) Komunikatyvna praktychna filosofiia [Communicative practical philosophy]. Kyiv: Libra. (in Ukrainian)

\section{Information about the author: Horban Yurii, orcid.org/0000-0001-5837-4409}

$\mathrm{PhD}$ in Cultural Studies, Associate Professor

Kyiv National University of Culture and Arts 36, Ye. Konovaltsia Str., Kyiv, 01133, Ukraine 


\section{DESIGN AND ARCHITECTURE IN THE AGE OF POSTMODERNISM}

\section{Bondar Ihor}

\section{INTRODUCTION}

Postmodernism as a certain age, instruction of creativity, intellectual play, means of interpretation and rather complicated reality of culture is generalized and transformed into a self-sufficient aesthetic form in architecture. Today, architecture is one of the leading, relevant and together intellectually intense regions of creative thinking, where a huge experiment of both prognostic and design artistic immersion into the space of the future is taking place. Architecture is increasingly drawn to design creativity, and in today's "non-linear" architecture, buildings are being transformed into modern design objects. It is important to determine the very technology of transforming the architecture's art into the design. It is necessary to reconstruct the design technologies of creativity in the context of postmodern architecture's poetics of architecture.

Deconstruction, which was cited as the principle of postmodern aesthetics in general, was an unwavering toolkit and the project mechanism of creativity at once becomes a marginal way of thinking and a regulator of creativity. It can be said that the design objects of architecture as a cultural and historical reality is a sufficiently avant-garde art region, which is ahead of all other artistic practices. Architecture as the most established and jointly universal practice has more responsibility than literature, music, painting before the future.

If music and literature have become a mess, a madness where simulacra, according to J. Baudrillard, destroy reality per se, then in architecture, simulation is always problematic. Now, all the views of postmodern theorists are focused on architecture, because it is here that the theoretical and practical symbiosis of artistic practices that turn into a show, into a certain system of dialogue and all other semiological and linguistic games of architectural language is carried out. The language of architecture becomes a self-sufficient mechanism of cultural creation. 


\section{Understanding the Architecture of Postmodernism as a Cultural-historical Reality}

The relevance of understanding the architecture of postmodernism as a cultural and historical reality is determined by the fact that this reality has already taken place, occurred as a certain series of artefacts, a series of events of creativity, an evolution that has development, rise, fall, new rise and new fall. And it has again a new take-off, which is waiting for its fall when it can already be argued that the day of postmodernism will lose the prefix "post". Post-postmodernism, as it's defined by N. Mankovska", or "post culture", according to V. Bychkov", is a kind of metalogisms or metaphors, trails of aesthetic or art criticism, which help to enter the space of post-decoding, post-realism, post-mythologization as deconstruction and modern symbolism. Finally, deconstruction mimics - changes from classical dismantling and assembly of elements, transforms into a continuous uninterrupted flow of artefacts, into a "fold", by J. Deleuze ${ }^{3}$, which becomes the leading imperative or mythological image of the late architectural creativity of Peter Eisenman, Zaha Hadid, and others.

One can see how during one life, one rather small temporal configuration of cultural creation, from the 60s to the present day, an extremely dramatic series of events took place, which constitutes the history of the postmodern movement itself, the history of postmodern architecture. However, such paradigmatic features of postmodernism as uncertainty, fragmentation, unpresentability, irony, carnivalization, deconstructivism, immanence are cross-cutting. The external phenomenological reality of architectural creativity changes, because the very state of certain destruction, uncertainty, anxiety and disquiet remain identical. All these realities suggest that architectural design objects, as cultural and historical realities, produce and demonstrate self-sufficient

${ }^{1}$ Bychkov V. V., Mankovskaia N. B. (2018) Sovremennyi vzgliad na estetiku simvolizma [A modern look at the aesthetics of symbolism]. Vestnik slavianskikh kultur, vol. 50, pp. 246-265.

${ }^{2}$ Bychkov V. V. (2003). Predelnye metamorfozy kultury - itog XX veka [Limit metamorphoses of cultures - the result of the XX century]. Leksikon Nonklassiki. Khudozhestvenno-esteticheskaya kultura XX veka [Lexicon of Nonclassics. Artistic and aesthetic culture of the XX century]. Moskow: Rossiiskaia politicheskaia entciklopediia, pp. 255-281.

${ }^{3}$ Deleuze G. (1997) Skladka. Leybnits i barokko [Fold. Leibniz and Baroque]. Moskow: Logos. 
disharmony as chaos, as total eclecticism, which transforms disharmony into a new cosmos, the image - a world of postmodernism.

All this requires meticulous analysis and differential definition in various aspects. Such as allusions (cultural and historical borrowing of architectural realities), citation and inversion. The irony and double coding or self-denial of creativity is that component of postmodernism that becomes total for the architecture and culture of the twentieth century, of all styles: modern, avant-garde and postmodern. This is ornamentalism as a play of style presentations and the profound reality of culture, where ornamentation is not just a decoration, but modulation and a certain demonstration of temporality as a living organism, the existence of artistic organisms. Temporality in architecture is always equal to eternity because sometimes architectural structures are transformed into means of denying eternity and demonstrating the variability of being. The dynamics in architecture is approaching the dynamics of living objects. These are the latest versions of the nonlinear architecture of postmodernism. All these aspects are peculiar aesthetic phenomena and peculiar components of a series of evolutionary architectural creativity of postmodernism.

The term "postmodernism" is believed to have originated a long time ago, in 1930, in a sense that was not yet related to its current understanding. Only in 1949, it received a nomination that was close to the present one. For the first time, it was determined by Joseph Gadnath, who published an article about the postmodern house in the book "Architecture and the Spirit of Man" in 1949. After all, this work is purely protopostmodern. Ch. Jenks's book "The Language of PostModern Architecture", has already legalized the notion of "postmodernism" as a fundamental concept that outlines the realities of "post".

In 1979, the article of French philosopher Jean Francois Liotara "The situation of Postmodern" was published, the concept began to be legitimate as a philosophical myth and philosophical construct, which in fact said that the boundaries of the postmodern Aesthetics' space had already been defined ${ }^{5}$.

4 Jencks Ch. (1985) Iazyk arkhitektury postmodernizma [The language of postmodern architecture]. Moskow: Mir.

5 Lyotard J. F. (1995) Situatciia postmoderna [Postmodern situation], Filosofskaya i sotsiologicheskaya mysl, no. 5-6, pp. 15-38. 
The concept of "postmodernism" correlates with the term "postmodern" in the broad sense, as Jürgen Habermas defined it ${ }^{6}$. This is the stage of culture that emerges as a post-classical era. Classic with its dogma of spirit, the mind is replaced by a non-classical image of the universe, where all the dogmas are dropped from the pedestal. Instead of the mind, it is the madness that becomes the constructive axis of postmodernism. After all, non-classical reality quickly turns into postclassical, where the mind and madness are combined, there is a certain middle stage. It is no longer possible to determine the boundaries of reason and madness. Of course, philosophical games look for their linguistic equivalent, and this equivalent is found in the spheres of culture: in linguistics, architecture, painting, and other cultural practices.

It can be argued that the "modern-postmodern" dichotomy and the more sophisticated "modern-avant-garde-postmodern" construction reflect the types of reflection - binary and ternary if these systems are defined, by Yuri Lotman. Binary systems are denied by ternary systems. If binary systems resolve the contradictions by explosion, disasters, then ternary eliminates catastrophes to the periphery.

One of the first synthetic attempts to make sense of postmodernism as a symbiosis of cultural creation belongs to the American researcher I. Hassan, who already tried to characterize postmodern realities as poetics or the integrity of the semiologically defined in 1986. "Such characteristics of Art Nouveau, according to I. Hassan, are uncertainty, fragmentation, decanization, lack of independence: unpresentability, irony, hybridization, carnivalization, participation (performance), constructivism, immanence" 7 .

The number of researchers trying to describe the culture of postmodernism in mythological and metaphorical features is expanding. They find fundamental for postmodernism metaphors that are quickly adapted to architectural reflection. These are metaphors of rhizomes, plateaus, folds. These are the constructs that play out and become favourite moves of already architectural thought in Peter Eisenman and others.

${ }^{6}$ Habermas J. (2000) Strukturni peretvorennia u sferi vidkrytosti. Doslidzhennia katehorii hromadianske suspilstvo [Structural transformations in the field of openness. Research on the category of civil society]. Lviv: Litopys.

7 Starodubtseva L. (1998) Arkhitektura postmodernizmu [Architecture of postmodernism]. Kyiv: Spalakh. 
After all, deconstruction as a topological program becomes crosscutting. It is transformed from elementalism, primary poetic instrumentation and changes into a more complex substance code. The ambiguity of life, being in two dimensions or "double coding", according to Charles Jenks, creates a world where an architect, a specialist and a man from the street live in one object, knowing and not knowing that it is one world and one culture, one century. Ambiguity is a profound substance of the anthroposphere, living anonymously, outside the subject and object of architectural discourse. Postmodern reflection as total eclecticism has its visual architectural agencies. This phase characterizes the early period of postmodern eclecticism. Thus, the work of Charles Moore, built in New Orleans, USA, is an extremely eclectic work that resembles a certain theatrical scenery in its theatrical buoyancy. This work is a kind of visionism, suggestion, moreover, a mystery. The architect creates an extravaganza of architectural forms that exist as signs, commas, dots in the text, which is a continuous aquifer of quotations from the architectural world constructor "LEGO". No wonder Jenks considers this work a landmark and even places it on the cover of his book ${ }^{8}$. This work is a sign of the initial stage of postmodernism. This is visionism, visual agencies, collages, the endless waterfall of quotes. But this is also the primary stage, which can be defined as the primary simplicity, behind which there is a stage of advanced complexity and second simplification, according to Mykola Leontiev.

The second stage is in turn defined as the denial of eclecticism, or the totalization of eclecticism, which already finds more complex images than visual stringing of forms. Architectural design objects are understood differently: as allusion, collage, pastishe, bricolage, irony, palimpsest etc. All these realities are architects and artists endlessly discussing and endlessly writing. All significant find new architectural and artistic images, art forms. It can be assumed that Robert Venturi has already identified two mythologists: the "duck" and the "beautifully decorated shed." Duck is a plastic form in architecture that is, in fact, the imitation of modernism, and a beautifully decorated shed is an allusion, a game of archetypes, symbols, a projection on the architectural form of deep protoforms, which at the subconscious level are revealed in the space of designing postmodern architecture. R. Venturi writes, "In

8 Jencks Ch. (1985) Iazyk arkhitektury postmodernizma [The language of postmodern architecture]. Moskow: Mir. 
architecture, I like complexity and contradiction; I do not like the arbitrariness or persistence of poorly written architecture or the complexity of delicately refined painting or expressionism"9.

Difficulties are the very school, which creates the images of the already developed stage of postmodernism. The ugly and mundane architecture or the decorated shed is already a manifesto that is proclaimed as a dichotomy of sign and form or signified and defined. It can be argued that the problem noted by Venturi very quickly becomes a representative mask of postmodern architecture because of the complexity of hiding the simplicity, the proto-symbol, which is clearly defined by Venturi. The work like Brant-Johnson-House in Verley, the USA, is one of those interesting formal innovations where the building combines the metaphors of the Jewish synagogue and the simple image of the house, combined with Scandinavian architecture. It is even important that one of the first works - his mother's villa - is also a kind of manifestation of everyday life and ugly, which in postmodern architecture is a kind of populism's mask, according to K. Frampton, who brings man closer to nature and the grey mass of subjects of postmodern discourse. Charles Jenks identifies already in his book "The Language of the Architecture of Postmodernism" those components of postmodern architecture that become fundamental principles and principles of postmodern architectural poetics: "In my opinion, there are no compelling examples of radical eclecticism, except for the famous structures of Antonio Gaudi; only weak hints as to what this maybe is in designers such as Bruno Reichlin in Switzerland or Thomas Gordon Smith in California." However, in general, some aspects of it have now been clarified. Unlike the "new movement", radical eclecticism resorts to a full range of communicative means of metaphorical and symbolic, spatial and formal. Like traditional eclecticism, it chooses the proper style or subsystem where appropriate, but mixes these elements in one structure. Thus, semantic overtones of each style are used in their closest functional equivalents" 10 .

The period of stagnation, which begins after trying to find a new image of simplicity, returns to a rather real problem that is experienced in the last post-classical period of the postmodern period of architects'

9 Starodubtseva L. (1998) Arkhitektura postmodernizmu [Architecture of postmodernism]. Kyiv: Spalakh.

10 Starodubtseva L. (1998) Arkhitektura postmodernizmu [Architecture of postmodernism]. Kyiv: Spalakh. 
creativity, which is connected with the so-called search for nonlinearity, a departure from all attributes of postmodernism. If we consider that the deconstruction of the blossoming complexity period was manneristic, the essence of the modernism's colour, then the post-classical period is a radical departure from modernism. But this radicalization, no matter how radical it may seem, is again a mask, an element of play, irony, because it will not be possible to escape from modernism, it is doomed to be "post". And so it is important that any search for a new simplicity or a new simple image is connected with the radical destruction of culture, and this radical destruction arises from the mythology of the elimination of culture and appealing to nature. Moreover, the appeal to the microworld, the cells, the atomic depths of the creative laboratories of nature, which create life on their own.

That is, the microcosm, which becomes an analogue of the macrocosm at the level of architectural world-building strategy, is defined as immersion in the mystery of the microcosm itself that generates the macrocosm. There seems to be nothing new here, but postmodernism has never sought anything new. Subsequently, the search for analogues in culture, in the environment is replaced by the search for analogues in nature. It is that meta cultural or natural paradigm that is associated with the meta-ecological problems of today, with the total image of the irrelevance of the world, which becomes the image of the undisclosed expansion of the human being that destroys nature around him.

Of course, architects approach these realities more consciously than other subjects of artistic and cultural practices, and architecture reflects on these issues more vigorously and tries to react and create images that are objects which carry the image of human protection. The image of the building as a home becomes a "green architecture", an ecological architecture of the future. Unlike the architecture of modernism, all the sympathies of postmodern architecture belong to the past. The future, futurism, is the formative antisense from which the postmodern architect moves. With the advent of J. Deleuze's works, a rather peculiar metaphoric situation arises. In the design space of the rhizome architecture is a well-known image that becomes a creative image of the designer $^{11}$.

11 Deleuze G., Gvattari F. (2010) Tysiachi plato. Kapitalizm i shizofreniia [Thousands of plateaus. Capitalism and schizophrenia]. Yekaterinburg: U-Faktoriya; Moskow: Astrel. 
There is a certain system that has the ability to develop itself. Instability of Deleuze corresponds to the concept of instability in physics. The notion of a plateau or place that creatively generates the relevance of the relationship between the singular, single components of the rhizome is a metaphor that makes it possible to speak about a thousand plateaus about the unlimited possibilities of creative creation created on the border of nature and culture. That is, the boundary of the natural-cultural continuum becomes an extremely interesting means of interpretation. And this is where computer technologies that help visualize biotechnology technologies are being immersed. Peeking into the microcosm is deployed as a certain microcosm that transforms almost unchanged into project practice.

Changes occur through interpretations. The works that arise in this context must be quite different. It is the work of biologist-scientists, who study the state of the modern vision of space as a creative potential, it is purely philosophical and architectural work. Researchers look at examples in biology and try to design them in the context of culture and art. Researchers talk of "intensity" as a sign of architectural form, of design stresses, which are determined by analogy with living systems. This is not a new idea, but it has a new tectonic understanding and new technology of its development. There is a problem of a new monadology, elementality, singularity, where separation is together with the universe.

An architectural image and an architectural object, falling into these complex interpretive theories, definitely require a completely different vision. In the architecture of postmodernism, most of the realities identified at the end of the twentieth century are those of the technocentric paradigm, where computer technologies come into almost direct contact with the creativity of nature and make it possible to formulate the credo of architects. Bionism and vitalism are experiencing a new birth. It is also important to note that the reflection of practising architects is one of the extremely important components of the design process. Thus, K. Kurokawa talks about architectural symbiosis, about metabolism, he not only denies philosophical or any other slogans, but tries to build his own concept. The same can be seen in ideas of Robert Venturi, F. Johnson, S. Quinn and others.

It is important that a certain principle of the essayistically polar and polysemantic worlds is formed. Design is beginning to be seen as a certain ontology conflict. Beginning with the early juxtaposition of the group of five, led by Peter Eisenman, to the boundless eclecticism of the visual sample, there is a reflexive multi-structured mottled fabric of the 
design space. If the group of five began with outright linearity, geometry as the periphery of modernism (it was a sharp work with modernist objects), then it adapted the principles of the nonlinear text. We can assume that the period of complexity and the heyday of postmodern architecture quickly ends and instead comes the simplicity, which is a marker of the boundary of culture and nature, meta-ecological issues, the unity of man and the universe.

It is suddenly discovered again that the universe is nonlinear, and the nonlinearity itself, the infinity of spatial artefacts of culture and nature, suddenly returns to the architecture. Kise Kurokawa writes in the work of "Value Prediction": "It is not difficult to see that postmodern architecture will evolve as architectures of small and heterogeneous cultures, the architecture of deconstruction, architecture that puts itself out of the centre. In this sense, it often looks like the architecture of a mixture, a tendency to hybridize, but it is a fundamental rejection of eclecticism, where historical architectural styles are simply mixed. Because there is no single ideal architecture and one perfect image, the architecture expresses not a single value system. It is a conglomerate of many different systems, or an image inherent in many different elements" ${ }^{\prime 12}$.

\section{Architecture Design-objects of the Postmodernism Era}

Postmodern sensuality from turns into a rhizome, where the plateau of forms creates its unexpected topology, which must be either catastrophic, or dramatic, or stochastic, unpredictable. All the aesthetic predicates and signs of this movement do not yet have any established nominations, but they already claim that the period of disorder, chaos has already passed. A new cosmos is created on the basis of total sensing of natural creative dimensions. These natural creative dimensions, as a meta-ecological horizon, speak of the location of a man in the Universe, on the Earth planet, of entirely new spatial realities of the architecture. Architectural reflection becomes a symbiosis of philosophical, cultural, linguistic and artistic, architectural thought, where the practising architect becomes a philosopher of space, time. With M. Heidegger begins the march into the reflexive mythodrama and the mythogenic

12 Starodubtseva L. (1998) Arkhitektura postmodernizmu [Architecture of postmodernism]. Kyiv: Spalakh. 
situation of transformations of realities of text substructures, from which the body of architecture is formed.

Architecture design objects are no longer architecture. Allusion arises on the border of culture and nature. This is another dimension of allusions. The tower in the Czech Republic is anthropomorphic in size, speaks of the object as installing shapes that resemble a negative type of architecture, is an analogy of immersion in a rock. The rocks as such are not present, but they have grown as certain layers of earth that are placed on top of each other.

There is an interesting paraphrase or parody. It is a kind of installation made in Japan by Aldo Rossi with Maurice Adumi, Palazzo Hotel, Fukuoka, in 1987 -1989. I. Dobritsin writes that the Rossi Hotel almost repeats the painting "The Riddle of Time" by Giorgio de Chirico, 1924. Tubular colonnades were created in Rossi, a high-tech metal taste was added, a surrealistic spirit of construction was strengthened, realistically interpreted in the context of classical architecture archetypes ${ }^{13}$. Interestingly, that such an allusion, which is spread not in a distant time, but the near is a certain deconstruction. That is the appeal to modernism, and together with its surreal colouration, which carries a deeper code, which again returns to the fundamental origins of archaic culture. The metal colonnade, which is laid in the middle of the structure, returns to the verticalism of the Menhirs, to the colonnade as a metric row in Ancient Greece, in general, to verticalism as a principle of intense metric and civilization as such. Of course, the image of civilization as the image of the vertical here is complicated, coloured and allusionistically transformed, because it is the image of the vertical, that is, the image of the vertical standing of man in the world.

We can say that the design objects of architecture here have a victory, imitate the principle of obelisk, menhir, complicate it, pluralize, fit a column into a shallow niche, interrupt it with horizontal. Horizontal stratification argues with the vertical metric because we still read flashes of vertices that permeate all horizontals as the horizons of the Earth, namely the upward elevation is nominative. Symbolism and irrationalism, mysticism, intuitionism as the deep foundation of this allusion show an extremely metaphorical and together capacious image.

13 Dobritsyina I. (2004) Ot postmodernizma - $k$ nelineinoi arkhitekture [From postmodernism to nonlinear architecture]. Moskow: Progress-Traditsiya. 
A peculiar conceptual allusion is the work of Peter Eisenman's "House 11", the conceptual project of $1978-1980$. Ch. Jenks notes that the building shows a series of signs, fragments in the form of the Latin letter "L", symbolizing instability and incompleteness, a kind of march into the letter world or the literal-structural reality of culture. It is worth mentioning that it is the Jewish culture, as one of the most archaic, that has a deep connection with the letter-writing that is valuable.

Thus, it can be argued that allusion, as the game reality of formformation in postmodern architecture, is the dimension that makes it possible to interpret creativity in different landscapes of architecture - in anthropogenic, geocentric, semiological, linguistic - and to correlate all these features with metamorphosis. can be called intuitive illumination or insight of integrity on the basis of comparison of hints. Finding, combining, and defining quotations, contexts, forms as realities of a particular hypertext or metatext arises in time and space "here and now". If we get rid of this dimension "here and now", then it will not be postmodern. The allusion is the unity of the present, the future and the past. The past and the future are manifested by spatial and temporal artefacts, which are defined as metonymy and metaphor. In fact, this rhetorical mechanics becomes a language of architectural harmony, but it unfolds consistently in each master's work in different ways.

An extremely active mechanism of postmodern poetics is irony. Unlike allusion, the principle of hinting at the reflection, dialogue, polylogue, the irony is a more archaic principle, which is associated with the dichotomy, the doubling of the subject of discourse, with the fact that the language or speech of discourse (in this case, the discourse of architecture) is doubled. The subject or semi-subject of the discourse determines another, and the other is immediately disavowed. Disavowing, that is, eliminating another, is called "irony". If you find any analogues, then, in the postmodern context, we can define the ancient irony, the irony of the classics, that is, German classical philosophy, the irony of romanticism. The principle of irony is the doubling of reality, as well as the interpretation of that reality.

The irony in antiquity was a purely external principle of defining a different voice that existed in dialogue rights, but this dialogue was a monologue. That is, dialogue existed as a form, and behind it, there was a radiological, that is, a monological form of expression or definition of meaning, which was masked under the mask of dialogue. All the dialogues with Socrates, all the irony that is hidden in the sentiments of Socratic philosophy, says that this is an irony of a purely orange type. 
That is, the meaning is unchanged, equal to cosmology, the cosmic device of determining the truth. Fate remains that unshakable core, but irony exists as an opportunity to see another as a response to another, the constitution of a certain meaning.

The irony of classical German philosophy is that the transcendental subject is a certain spectre, a certain allusion, as we have already defined it by the linguistic features of postmodernism. It exists as an aggregate of consciousness, or as a certain surreal construct of universal consciousness, which is accessible only within the individual subject of the action, that is, the substantiation of consciousness, which was defined as a transcendental subject. There is a certain ironic description, that is, an ironic description or an ironic distancing from "I am individual" to "I am universal".

What is the irony here? It is that the universal transcendental entity is a ghost, constituted as an absolute, but it is only an agreement or witness to some universal agreement between all existing entities. Of course, this irony is not explicit, implicitly defined, exists as a complete transcendence, a transition beyond the limits of "I of everyone" to "I am universal", which exists and does not exist. This alternation of existence and non-existence can be defined as irony.

The next stage, defined by O. F. Losev as romantic, is due to the fact that the irony deliberately takes on the construction of reality ${ }^{14}$. Just as Schelling constructs the universe of his philosophy of art, so irony constructs the universe. He refers to him from the position of the subordinate "I", who only reads or read out himself in the arms of the transcendental subject, but becomes himself the epicentre of creation, which sees the whole world in reduced tones. That is, the romantic irony is arbitrariness, sniggering, diminishing reality. It is the reality of consciousness as a universe of romantic being, understood as my personal world.

When an artist, an architect begins to analyze what is being formed, he doubles the world "here and now", devalues reality in such a way that he tries to define some values, and in the manner of irony to rise above all the contradictions of the world, he fails. The irony of antiquity was purely superfluous, signifying dialogue within a monologue. The irony of classical German philosophy was a totalitarian mechanism for

${ }^{14}$ Losev A. F. (1997) Problema simvola i realisticheskoe iskusstvo [Symbol Problem and Realistic Art]. Moskow: Iskusstvo. 
projecting the general into the single. The irony of romanticism, on the contrary, is the projection of the individual into the universal. After all, the irony of postmodernism is eclecticism, the unity of all possible types of irony - from hidden dialogue, monologic reality to the definition of the absolute through the single, the test of the absolute for authenticity and authenticity, and, conversely, the projection of the single special for the universe.

All these points of view can be used in turn in the postmodern discourse of architecture, or coexist in the same work. This is the complexity of irony because irony is not a simple mechanism of arbitrariness and play. The game also exists here. But if in a game a person exists in two worlds - here and there, then irony can exist in one world: either in the world here or in the world there, and it can exist together in two worlds. This complexity, the drama of irony as a principle of cultural formation, the formation of the fact that this opportunity to be different is in postmodernism. Postmodern philosophy, in particular, has quite complex implications and complex selfdefinitions, so double coding has been imparted from literary texts to postmodern architecture.

The postmodernist type of thinking suggests that code or language as a way of conveying information is distinctive, and how it is reproduced suggests not only that it is banal and elitist information, but that there is a doubling of problems of values.

Who is the ironist in postmodernity? The problem is the process of irony or ironic worldview itself. When the world is understood as a juxtaposition of two aspects of "here and there" where the game can act and not act, the subject may be absent, and the irony is not because someone wants it, but because the object itself is ironic by their definition, by the mechanism embedded in it of the identity of "I" and "you", which on the basis of allusion send to completely different worlds. That is, we see that irony is a polyphonic mechanism for the identity of "I" and "you".

The irony in one way or another imitates binaries and continues the same dichotomy code that is characteristic of archaic systems. It can be argued that irony does not become a dialectic because dialectics has all the prerequisites for resolving contradictions. The ironist problematizes the contradictions and eliminates them through an active will or by eliminating one of the objects of ironic disposition: the absolute or the subject. We see either a wholly absolute or wholly subjective world, one way or another the result of a self-fulfilling mechanism of irony. 
Conceptually, the mechanism of allusion and the mechanism of irony in postmodern aesthetics are very similar. The allusion mechanism begins with a hint and a simple appeal to a multifaceted and multiple reality. The subject substantiates intuition as an upstream principle of shaping. The mechanism of irony begins with a doubling, the dichotomy plunges into the subject and evokes that deep monologism that tends to dialectic as a unity of contradictions. This mechanism is objectified and brought out, transformed into the space of all possible worlds. The ironist looks like an anonymous figure, as the missing subject, only the irony remains as a game, echoes, reflection of the worlds.

If we refer to a rather simple and clear scheme of Yu. M. Lotman, who said that all binary systems were connected with catastrophes, with a simple solution of contradictions. The dialectic here is also complete catastrophism as a solution of contradictions by an explosion, then the solution of contradictions in ternary systems is the elimination of contradictions to the periphery when the contradiction is eliminated and a mediator appears instead. The third interim term appears - the "I" mask or the "you" mask.

It seems that postmodern irony is a complete set of all possibilities catastrophic and, conversely, quiet, catastrophic, ways of resolving contradictions. Postmodern irony, dominated by the eclecticism of thinking, the eclecticism of vision and the eclecticism of interpretation, is the doubling, tripling, pluralisation of a subject when he or she occupies more than one position or meta position, but is on the verge of all positions or holds all positions together. To make all of the above seem more transparent and clearer, it makes sense to turn to examples, to illustrate the mechanism of irony in the context of dual coding in works and in the reflexive systems of postmodernism.

The irony is a certain drama, a certain danger, a denial that says that postmodernism is a denial of modernism, a denial of the classics. But the objection is on very different grounds. These grounds may belong to both the entity and the object. That is, it belongs to either the culture or the figure, that is, the subject of that culture. All these problems are extremely acute in determining the type of irony and the type of irony that works or does not work or is completely eliminated from the field of cultural creation. The death of the author, according to R. Barthes, is not 
just a metaphor, but also an ironic disposition, which says that the author is not and cannot be $\mathrm{e}^{15}$.

If we consider the evolution of postmodern thinking in architecture, we can identify three phases that have already been discussed: the early period of primal simplicity associated with eclecticism, the intense combination of cultural facts, the period of flowering complexity, determined by the leading metaphors (beautifully decorated shed, ducks, etc.) and the last period where we see the emergence of non-linear architecture. The irony, oddly enough, looks quite difficult at all three stages of the evolution of postmodern architecture. Assuming that genetically primary is a period of monologism, and dialogue is merely an ironic colouration of this monologue in ancient Greece, then we can assume that the very principle of evolution of irony or types of ironic thinking, which can be defined as latent monologism, latent totalitarianism of consciousness or subjectivity the artist, the reflective subject of the classics, the ironic universe of romantics, where the world is reduced here and the disposition of the reduced (here) and the sublime (there) arises.

It can be said that the ironic configuration in the postmodern has an inverted appearance. This can be explained as follows. The last phase of postmodernism, that is, biopopulations and nonlinear text, is the creative analogue of the monism of ancient Greek irony, where any other is superfluous.

The meta subject of the classics is characterized by a period of blossoming complexity, a period of archetype formation, such a combination of sign, symbol and form, where irony itself looks like the harmony of eliminating the single, its generalization.

The romantic type of irony dominated by the subject characterizes the early stage of postmodern irony, which is associated with total eclecticism, extensive metric, metonymy. The irony is the same destruction that occurs as a blend of any fragments of culture. We can see interesting metamorphoses: the irony of postmodernism is inverted, it exists as a system genesis of types of ironic worldview. This is extremely interesting and extremely important: inversion and together transgression, the combination of all types of irony in the postmodern is

15 Bart R. (1994) Izbrannyie rabotyi: semiotika, poetika [Selected works: semiotics, poetics]. Moskow: Progress. 
a universal mechanism of vision, interpretation of creation, which is quite difficult to unambiguously describe.

The irony of postmodernism gains its features, in a rather universal world that is a symbiosis of culture, a subjective and objective combination of possible and impossible worlds. Creativity worlds, real worlds, and phenomenal worlds that give creativity to an ironic or creative subject. One might ask why in the postmodern this inversion occurs, why is the higher stage marked by monism and the first immersed in pluralism and eclecticism? It seems that every system that develops in the context of culture somehow completes its path of existence with a certain integrity, with a sufficiently simple and clear construction. That Rubicon, which is defined in the post-modern by biopopulations, appeal to nature, immersion in the microcosm, is the horizon of harmony, which is the monism of the natural sample, the key to the universality and generality of nature's creativity.

This stage should not be absolutized, there will be something else behind it, a new round of development, new nominations. But these are not our problems. Our problem now is to try to reconstruct the sequence of postmodern development in its three stages as a period of eclecticism, blossoming complexity, secondary simplification in measuring the types of ironic worldview. This is an interesting problem of double coding, where the code of ways of seeing, interpreting as speech is a way of communicating, conveying imagery, thought and feeling.

That is, we can say that in the early stages of postmodernism, which is connected with total eclecticism, is dominated by the romantic type of irony, it reduces contradictions, unites all artefacts of culture. It is very important to point out this type of irony as the starting point for postmodernism, and, moreover, postmodern romanticism, which almost no one has defined, is just ironic.

The samplings of the first romantic irony of postmodern architecture include not only cultural symbiosis, such as the square of Italy but also neoplastic symbiosis. Thus, we can also say about the Sydney Opera House in Australia, 1957-1973. It is is an early eclecticism or ironic romanticism, which arises precisely on the horizon of the rise of postmodernism as a kind of thinking and a kind of sensuality. One of the interesting epicentres, the explosion of such romantic irony in architecture, was the construction of the Velasquez Tower in Milan, Italy, 1958, built by a group of architects: L. Beljoiso, J. Banffy, E. Peresuti, and E. Rogers. "This building is a kind of scary caricature of skyscrapers. It fuels the interest in history, has a resemblance to the 
Viequio Palace. It is possible that the decor itself and the ornamental and decorative fatigue caused a sense of return to the roots "- this is what Lydia Starodubtseva defines this phenomenon ${ }^{16}$.

It could be considered a blast of the most romantic type when the roots were the fundamental reality that was immediately denied. It is interesting that during this time a type of romantic irony was formed at the turn of the 50s, 60s, 70s. This is not a style, but a way of seeing. In 1962, Louis Kahn created one of the interesting structures that is difficult to define in the context of pop art, but it has a certain geometric schema, which can not be called ironic. The monumental character of the images, which is associated with the pyramids and together carries certain allusions to the simple and clear geometry of the protoforms, characterizes the Parliament building in Dhaka.

This image seems to be a kind of modernist throwback in the context of the romantic irony of postmodernism. A kind of romantic and ironic gesture was the so-called "Venturi Rauch", a home for the elderly at the "Guild House" in Philadelphia, the USA, 1960-1963. Robert Venturi at the Guild-Gauss made a kind of experiment where he connected the everyday and the beyond. People are hidden behind the facades of a fairly ordinary house. The antenna symbolizes the otherworldly, is the epicentre of the ironic explosion. People are tied to the antenna as ghosts, they just have to watch TV.

So the irony plus grotesque, everyday life, brutalism and fatigue of life characterize this peculiar grotesque image, which is the image of total eclecticism that combines everyday life, the ordinary residential structure of a multi-storey configuration, carries a mockery of old age beyond which it is impossible to mock. This house is a kind of manifesto that carried out an ironic demarcation between the old age and youth of postmodernism. The youth is past, and the old age has not yet begun, for the ironic romanticism continues.

Finally, another stage arises that is linked to the blossoming complexity of postmodernism, which can be termed symbolic symbiosis. It is an irony of the implicit, hidden, irony of archetypes, which exists as a denial of reality on the basis of global ideas, concepts, global images. Thus, the architect T. G. Smith, the Takana Villa in Livermore, California, USA, 1979-1980, is the bearer of such archetypes. The

16 Starodubtseva L. (1998) Arkhitektura postmodernizmu [Architecture of postmodernism]. Kyiv: Spalakh. 
viscous pillar at the bottom, the arcade, the pillars raised above, all show the irony of the archetypal schematic type. Colonnade coexists with metal garage doors. It is an irony, but an irony hidden, which is masked, manifested by the syntagmatic of archetypal large forms.

An interesting image of the classical or middle period of postmodernism, where there is an irony that can be linked to the dominant common over the single, is the "Theater of the World", Venice, Italy 1979-1980, by architect A. Rossi. The building is associated with the Renaissance, carries a childish infantile. This unusual image fits into the space of mega-structures of classical culture, is quite a jewellery and thin game of volumes and spaces of the environment. It can be said that postmodernism gains self-definition in the context of other cultures, and allusion is no longer a matter of the subject of creativity but belongs to some general context, which neither the subject of discourse, nor the subject of creativity, nor the culture as such possesses.

A certain provocation was the Michael Graves utility house in Portland, which caused a scandalous controversy. It seemed that this project would never be built, but it was built. The overhead facade, painted cube, speaks of the idea of a beautifully decorated shed. It is important that this Mickey Mouse postmodern classicism, as it was labelled by critics, was a kind of wonderful shed for cheap swings. It is believed that this hypertrophied construction, which from the outset was a manifestation of the game hypertrophied classic structure, carried a certain provocation, and this provocation combines the postmodern with its classic features. That is, it reaches its prime as a symbolic stage. The concept defeats all phenomenal values. These phenomenal values are romantic and postromantic at the same time, carry the universal classic impulse or format of victory of the common over the singular, and show the developed phase of irony as casting over the universe, over the classics, the primacy of decor over the truth.

\section{CONCLUSIONS}

Summarizing the above, it should be noted that one of the first synthetic attempts to make sense of postmodernism as a symbiosis of cultural creation belongs to the American researcher I. Hassan, who tried already to characterize postmodern realities as poetics or the integrity of semiological characteristics in 1986. Nowadays, the postmodern theorists' attention is focused on architecture, because it is here that the theoretical and practical symbiosis of artistic practices, which in 
architecture turn into a show, into a certain system of dialogue and all other semiological and linguistic games of architectural language, takes place. Thus, the language of architecture becomes a self-sufficient mechanism of cultural creation. The number of researchers who attempt to describe the culture of postmodernism in mythological and together metaphorical features is also expanding. They find fundamental for postmodernism metaphors that are quickly adapted to architectural reflection. These are metaphors of rhizomes, plateaus, folds.

The atmosphere of postmodernism has introduced a new type of relationship between the architect and the theorist of architecture a reaction to the architectural type associated with the modernist tradition and what is called the international style has arisen. One of the major contradictions in the architecture of postmodernism was the combination of both a globally pessimistic vision of the cultural situation and an understanding of the need to continue being, despite the inability to solve global problems.

Considering the evolution of postmodern thinking in architecture, three phases are identified: an early period of primal simplicity associated with eclecticism, an intense combination of cultural facts, a period of blossoming complexity, determined by leading metaphors (beautifully decorated sheds, ducks, etc.), and finally the last period where we see the emergence of non-linear architecture. Moreover, we can say that in the early stages of postmodernism, which is connected with total eclecticism, the romantic type of ironist dominates, it reduces contradictions, unites all artefacts of culture. It is very important to point out this type of irony as a source for postmodernism and, moreover, for postmodern romanticism, which almost no one has defined, is namely ironic.

\section{SUMMARY}

Postmodernism does not deny the past, but merely ironically rethinks it, referring to decorative and brightness, kitschy and chic, individuality and imagery, quoting historical styles. The purpose of the article is to investigate the crisis perception of the situation in the architecture and design of the postmodern period, which exists in the mode of multicultural polylogue. The scientific novelty is determined by the fact that the article attempts to determine the foundations of crisis thinking of the architecture theory, which gives an opportunity to better understand the specifics of the ideology that shaped the style of postmodernism in architecture and design. The problems of the study are determined by the 
attempt to reconstruct the sequence of postmodern development in its three stages as a period of eclecticism, blossoming complexity, secondary simplification in the measurement of ironic worldview's types. Some examples of postmodern architecture have been considered and features of their style have been identified. Conclusions. Considering the evolution of postmodern thinking in architecture, we have identified three phases: an early period of primal simplicity associated with eclecticism, an intense connection of cultural facts, a period of blossoming complexity determined by leading metaphors, and the last period where we see the emergence of nonlinear architecture. Moreover, we can argue that in the early stages of postmodernism, which is associated with total eclecticism, the romantic type of irony dominates, it reduces contradictions, unites all artefacts of culture.

\section{REFERENCES}

1. Bart R. (1994) Izbrannyie rabotyi: semiotika, poetika [Selected works: semiotics, poetics]. Moskow: Progress. (in Russian)

2. Bychkov V. V. (2003) Predelnye metamorfozy kultury - itog XX veka [Limit metamorphoses of cultures - the result of the $X X$ century]. Leksikon Nonklassiki. Khudozhestvenno-esteticheskaya kultura XX veka [Lexicon of Nonclassics. Artistic and aesthetic culture of the XX century]. Moskow: Rossiiskaia politicheskaia entciklopediia, pp. 255-281.

3. Bychkov V. V., Mankovskaia N. B. (2018) Sovremennyi vzgliad na estetiku simvolizma [A modern look at the aesthetics of symbolism]. Vestnik slavianskikh kultur, vol. 50, pp. 246-265.

4. Deleuze G. (1997) Skladka. Leybnits i barokko [Fold. Leibniz and Baroque]. Moskow: Logos. (in Russian)

5. Deleuze G., Gvattari F. (2010) Tysiachi plato. Kapitalizm $i$ shizofreniia [Thousands of plateaus. Capitalism and schizophrenia]. Yekaterinburg: U-Faktoriya; Moskow: Astrel. (in Russian)

6. Dobritsyina I. (2004) Ot postmodernizma $-k$ nelineinoi arkhitekture [From postmodernism to nonlinear architecture]. Moskow: Progress-Traditsiya. (in Russian)

7. Habermas J. (2000) Strukturni peretvorennia u sferi vidkrytosti. Doslidzhennia katehorii hromadianske suspilstvo [Structural transformations in the field of openness. Research on the category of civil society]. Lviv: Litopys. (in Ukrainian)

8. Jencks Ch. (1985) Iazyk arkhitektury postmodernizma [The language of postmodern architecture]. Moskow: Mir. (in Russian) 
9. Losev A. F. (1997) Problema simvola i realisticheskoe iskusstvo [Symbol Problem and Realistic Art]. Moskow: Iskusstvo. (in Russian)

10.Lyotard J. F. (1995) Situatciia postmoderna [Postmodern situation], Filosofskaya i sotsiologicheskaya mysl, no. 5-6, pp. 15-38.

11.Starodubtseva L. (1998) Arkhitektura postmodernizmu [Architecture of postmodernism]. Kyiv: Spalakh. (in Ukrainian)

\section{Information about the author:}

Bondar Ihor, orcid.org/0000-0001-8972-0941

Associated Professor,

Honourd Worker of Culture of Ukraine Kyiv National University of Culture and Arts 36, Ye. Konovaltsia Str., Kyiv, 01133, Ukraine 


\section{KOBZARDOM AS A PHENOMENON OF UKRAINIAN CULTURE IN THE CONTEXT OF THE NEW REALITIES OF DEMOCRATIZED SOCIETY}

\section{Furdychko Andrii}

\section{INTRODUCTION}

In Ukrainian folk culture, many phenomena attract the attention of not only experts but also a certain circle of fans of folk art. Among them, the phenomenon of kobzardom is of particular significance. Its evolution, as well as other cultural phenomena, went through periods of formation, prosperity, decline, branching into two trends (reproductive and productive), revival in the days of Ukraine's independence. The discussions that are being held today between supporters of authentic kobzardom and representatives of the academic bandura performance concern the degree of approximation of each artistic direction to the true origins of this unique musical and social phenomenon of Ukrainian culture. But, at the heart of the contradictions, the main issue is the prospect of further development of this genre. Thus, despite the different views on kobzardom in different schools of performance, the only consensus on this issue is the unique phenomenon of the objects of a kind of dispute - „kobzas, lyres, banduras”, which encode the creative mental code of Ukrainians, ancient traditions and the history of the Kobzar movement itself. According to M. Budnik, one of the founders of the Kyiv Kobzar workshop: "... Only a song can bring us back in time, and a musical instrument can guide our journey and become a guide horse" ${ }^{1}$.

The study aims to analyze the development of kobza art in the historical and musicological aspects, to determine the impact of the Kobzar heritage of the Ukrainian people on the current state and the prospects of its further development, which is a novelty of the essence of

1 Yezhel Yu. (2017) Zrobysh banduru - vizmemo: Yak "posviachuiut" u suchasnykh kobzariv [You make the bandura - we will take you: how modern bandurists "are consecrated"]. Ukraina Moloda [Ukraine Young], 25 June, p. 13. 
the problem. The research methods are based on historicism, analysis, and synthesis of structural elements of this musicological phenomenon.

The historiography of kobzardom is extremely voluminous. Among collectors and propagandists of kobzars' creativity, we note M. Lysenko, P. Demutskyi, F. Kolessu, K. Kvitka, O. Slastion, O. Rozdolskyi, and others. Scientists have studied various aspects of the Kobzar movement. V. Lomykovskyi, M. Tserteliev, N. Maksymovych, I. Sreznievskyi, P. Lukashevich collected Ukrainian dumas and historical songs; P. Kulish, P. Yefimenko, Ts. Neiman, V. Borzhkovskyi, K. Studynskyi, M. Speranskyi, K. Kvitka studied the life, traditions, and customs of kobzars, bandurists, and lyrists; V. Peretz, P. Zhytetskyi studied the texts and poetics of dumas; F. Kolessa, N. Hrinchenko studied their musical form; M. Lysenko, H. Hotkevych, A. Humeniuk, S. Bashtan, L. Cherkaskyi investigated the history of musical instruments; F. Lavrov, B. Kyrdan, A. Omelchenko studied the biographies of famous kobzars. In modern times, S. Hritsa, M. Hrymych, V. Noll, O. Dubas, V. Dutchak, M. Pidhorbunskyi and others are actively engaged in the study of kobzardom. In particular, the vocal issues of genres of the repertoire of bandurists of the twentieth century are discussed by A. Omelchenko, V. Mishalov, N. Morozevich, L. Mandzyuk, I. Panasyuk and others in their writings. The problems of the revival of works of traditional kobzardom on diatonic instruments are covered in researches carried out by V. Kushpet and K. Cheremskyi. The position of the modern reproductive trend of kobzardom is represented in the works of V. Yesypka, B. Zheplynskyi, etc. But the issue of folklore in contemporary kobza art still needs more detailed study.

\section{Beginnings of the Study of Kobzardom}

Kobzardom became a symbol of Ukrainians in the world in the twentieth century. For many centuries, it was a familiar phenomenon for Ukrainian society. Interest in it appeared in the second half of the XIX century when in the light of the humanistic ideas of the "spring of peoples" and the strengthening of the process of creating national states in some European countries, they began to focus on the history and culture of their people. Naturally, kobzardom evoked considerable interest. At the end of the last century, blind people, elders, singers, beggars, who went from village to village or in crowded places (at markets or near churches) performed historical songs, dumas, and psalms. They sang and played humorous songs at weddings and in places 
of entertainment. Their main instruments were kobza, bandura, hurdygurdy, and torban. Most often, kobzars performed their repertoire with recitative.

The process of collecting information, studying and analyzing this work has led researchers to understand the archaic genesis of this phenomenon and the depth of the mentality of its carriers. Today's experts on this problem see the origins of the Kobzar and Duma art in the Gusli and Bylina tradition of Kyivan Rus. Other scientists link the kobzardom directly with the heroism of the Cossack era ${ }^{2}$. However, at the time of the birth of interest in kobzars, the activity of blind performers of folk songs (XIX - early XX century) was at the final stage. The mood of their songs became mostly sad. The Cossack epic disappeared from their repertoire: only some moralistic themes remained in the dumas, with the so-called lower songs, or ballads, mostly in historical songs; the haidamaks' songs, songs about the destruction of Sich, songs of the Chumaks almost became extinct ${ }^{3}$. It was already the "miserable" period of kobzardom. However, the spirit of the kobzars had not been broken yet. They managed to organize themselves into brotherhoods, create their internal statute, secret language, establish the admission of new members, their training, and were allowed to enter the profession only after serious examinations ${ }^{4}$.

Interest in specific personalities of performers of the Kobzar workshop arose and grew in the late XIX and early XX centuries. Thanks to this interest, information about such kobzars as A. Shut, O. Veresai, M. Kravchenko, H. Kozhushko, F. Kushneryk, Ye. Movchan, P. Nosach, O. Chupryna, P. Suprun, M. Budnyk, V. Horbatiuk, and others has been preserved to this day. The records contain texts and melos of Kobzar texts. The life and customs of the elders are also studied. In short, an attempt is being made to investigate the world of this particular

2 Khotkevych H. (2002) Muzychni instrumenty ukrainskoho narodu [Musical instruments of the Ukrainian people] (Reprint 1930). Kharkiv: DVU, p. 295.

${ }^{3}$ Cherkaskyi L. M. (2003) Ukrainski narodni muzychni instrumenty [Ukrainian folk musical instruments]. Kyiv: Tekhnika, p. 12.

${ }^{4}$ Trembitskyi A. M. (2008) Arho nosiiv ukrainskoho "nezriachoho" epichnoho mandrivnoho mystetstva: stan naukovoi rozrobky problemy [The Cant of the Bards of the Ukrainian "Blind" Wandering Epic Art: State of Scientific Development of the Problem]. Ivan Ohiienko i suchasna nauka ta osvita [Ivan Ohiienko and Modern Science and Education], vol. 5, pp. 110-148; Suprun-Iaremko N. O. (2010) Muzykoznavchi pratsi [Musicological works]. Rivne: O. Zen, pp. 54-61. 
community, which earned a living by musical creativity, while preserving the archetypal elements of folk culture. The need to preserve an authentic musical instrument was understood. Researchers such as M. Lysenko, P. Demutskyi, F. Kolessa, K. Kvitka, O. Slastion, and others were the most active in this field.

They perceived the bandura's design options somewhat differently. But there was no significant difference between them. F. Kolesov, for example, distinguished them by the number of strings and prystrunky (unstopped treble strings): Ostap Veresai's bandura - 6 strings and 6 prystrunky; Pavlo Bratuts' bandura - 4 strings and 16 prystrunky; St. Petersburg Conservatory's - 4 strings and 13 prystrunky; Mykhailo Kravchenko's - 5 strings and 18 prystrunky; Hnat Honcharenko's 5 strings and 15 prystrunky; Ivan Kucherenko's -5 strings and 16 prystrunky; Taras Parkhomenko's - 6 strings and 14 prystrunky ${ }^{5}$. These instruments are today referred to as traditional, folk or old-world banduras. The shape of the resonator and the manner of performance depended on the specific musician. The one standard version did not exist, much depended on the creativity of the Kobzar and the master who had made the tool. For a long time, kobza and bandura were considered identical instruments, and their names were synonymous.

Long before the middle of the last century, the instruments were designed by the folk masters or the singers themselves. In the post-war period, the mass factory production began, which was required by the new conditions for their use by large orchestras. This, of course, required the unification of their design and range, the way of playing, etc. Nowadays, thanks to the activities of modern music masters, the legendary kobza-bandura is being radically reconstructed. So, if in the past its body was round, convex, and pear-shaped, today it has a convex shape with an asymmetrically set neck (as a result of increasing the strings); the number of basses and strings has been increased, and the sound range has been chromatized.

Some researchers of kobzars' creativity see a common worldview platform in topics devoted to the tragic pages of the history of the Ukrainian people, the struggle against oppressors, social justice, national liberation, everyday life, family relations, and morality. O. Bohdanova, for example, believes that her main moral and aesthetic principles were

${ }^{5}$ Kolessa F. (1969) Melodii ukrainskykh narodnykh dum [Melodies of Ukrainian Folk Dumas]. Kyiv: Naukova dumka, pp. 51-52. 
the comprehensive dissemination of ideas of religious preaching, a kind of "people's Christianity", which was closer and more understandable to ordinary people than the Church ${ }^{6}$. And this consideration, in our opinion, has a right to exist.

\section{Kobzardom in the Conditions of Soviet Power}

The social cataclysms which were brought by the First world war (1914-1918) and the civil war that completely enveloped Ukraine, and then the coming to power of the Bolsheviks radically changed the political landscape in the former Russian Empire, which became the Soviet Union. At the same time, a new state ideology emerged, which critically and sometimes mercilessly treated both religion and various prejudices. This category also included folk musicians-beggars who sang mournfully about the past and were not at all happy for the "bright future" that awaited the working people. Authentic kobzars, elders, blind singers got into trouble with the new government. And the new officials did not avoid bandit methods of dealing with ideological opponents. Kobzars I. Lytvynenko, A. Slidiuk, and F. Dibrova were killed by Bolsheviks in Ekaterinodar in 1919; and A. Mytiai, S. Sotnychenko, and P. Skydan - in 1920. The researcher of kobza art B. Zheplinskyi set up the register of kobzars and lyrists killed by the Bolsheviks or missing. There were 72 people in it ${ }^{7}$. In the mid-1920s, regulations were issued to struggle against traditional music ${ }^{8}$. Many kobzars died during the collectivization and Holodomor in 1932-1933, while others were subjected to repression and destruction ${ }^{9}$. There was a problem of fading of this genre of folk art, as unnecessary in the new historical realities.

${ }^{6}$ Bogdanova O.V. (2002) Lirnytska tradytsiia v konteksti ukrainskoi dukhovnoi kultury [Lyric tradition in the context of Ukrainian spiritual culture] (PhD Thesis). Kyiv: Ukrainian National Tchaikovsky Academy of Music, p. 3.

${ }^{7}$ Bozhko M. O., Pasko M. V. (2015) Dukhovni nastavnyky narodu: kobzarstvo $v$ Ukraini: Bibliografichnyi narys [Spiritual Mentors of the People: Kobzardom in Ukraine: A Bibliographical Essay]. Kyiv: Centralized library system of the Shevchenkivskyi district of Kyiv, pp. 41-43.

${ }^{8}$ Chaika S. V., Chaika M. M. (2012) Kobzarstvo - diievyi chynnyk zberezhennia tradytsii dukhovnoho zhyttia natsii [Kobzardom is an effective factor in preserving the traditions of the spiritual life of the nation]. Pedahohichna osvita: teoriia $i$ praktyka [Teacher education: theory and practice], vol. 12, pp. 439-446, p. 442.

${ }^{9}$ Cheremskyi K. (1999) Povernennia tradytsii. Z istorii nyshchennia kobzarstva [Return of traditions. From the History of the Destruction of Kobzardom]. Kharkiv: Les Kurbas Centre. 
Famous musicologist M. Khai felt this tendency in the development of instrumentation: "With the extinction of production-labor, ritual-rite, calendar and family-everyday traditions in most regions of Ukraine, the corresponding functions of folk instruments died out" ${ }^{\prime 10}$.

The new government failed to overcome such a phenomenon as kobzardom, etched into the national memory, immortalized by the creativity of T. H. Shevchenko. The course was chosen to create an academic bandura performance that would avoid religious motives. Two directions of the Bandurist's performing arts were gradually crystallizing, which were not separated by the way of playing, but by the forms of the functioning of the instrument, i.e. folk and concertacademic. The last one was closely related to the names of H. Khotkevych, L. Haidamaka, V. Yemets, and M. Teliha. ${ }^{11}$ Even contemporary Bandura art continues to evolve in two directions: kobzardom with the preservation of the traditional repertoire and the accompanying function of the instrument, with an effort to revive the authenticity of the instrumentation and performance (reproductive function) and academic bandura performance (bandurism), which is divided into solo instrumental, vocal-instrumental, and ensemble with an upgrade of the instrument design, its performance, and repertoire (productive function) $^{12}$. At that stage kobzardom as a social phenomenon almost disappeared and a new genre (academic bandurism) developed as an aesthetic phenomenon. The first concert performance of professional bandura performers (Bandurist Quartet) in Kharkiv in 1928 played a significant role in the formation of Bandura academic performance practice $^{13}$.

10 Khai M. (2007) Muzychno-instrumentalna kultura ukraintsiv (folklorna tradytsiia) [Musical-Instrumental Culture of Ukrainians (Folk Tradition)]. Kyiv; Drogobych: Kolo, p. 177.

11 Dutcheak V. G. (2010) Myhailo Teliga: postati myttsya v kontexti epohy [Mykhailo Teliga: The Figure of the Artist in the Context of the Era]. Naukovyi vistnyk Natsionalinoi Muzychnoyi Akademiyi Ukrainy of P. Cyaikovski, vyp. 91, p. 249.

12 Panasiuk I. V. (2008) Tvorcha diyalinisti S. V. Bashtana v kontecsti stanovlenya Kyivskoi shkoly akademichnogo bandurnogo vykonavstva [The Creative Activity S.V. Bashtan in the Context of the Establishment of the Kyiv School of Academic Bandura Performance] (PhD Thesis). Kyiv: Ukrainian National Tchaikovsky Academy of Music, p. 4.

${ }^{13}$ Vavryk O. (2006) Kobzarski shkoly v Ukraini [Kobzar Schools in Ukraine]. Ternopil: Zbruch, p. 133. 
Representatives of the new, "proletarian culture" were sometimes critical of Kobzardom as an art. There were opinions about the irrelevance and inappropriateness of the old bandurism to the new tastes. They expressed their reluctance "to return to antiquity in the age of electricity...". The other believed that the instrument died along with its era, its repertoire is outdated, and the bandura itself is "too quiet, too sad, not native to the proletariat, because it was not born in the smoke of factories or under the roar of tractors, and because of this kobza is not mass and not popular"14.

\section{The Productive Period in Bandurism}

Contrary to this understanding of the problem, the prevailing opinion of the power circles was that it was necessary to support this folk tradition and use it for the benefit of the new ideology. The productive function of bandurism began to improve. The growing interest in the art of kobzars should be acknowledged. This contributed to the appearance of kobzar instruments on the stage. Here it is more often called the bandura, not the kobza, and performers - both kobzars and bandurists.

One of the researchers of the evolution of Ukrainian folk instruments L. Cherkaskyi noted several directions of entry of the kobza-bandura in the sphere of concert activity in his monograph: 1) improvement of the instrumentation by extension of a sound line, introduction of chromatization, improvement of technical possibilities of performance, modernization of the design of instrument material, modernization of its production; 2) improvement of the level of performing skills through the study of music theory, mastery of high vocal technique and instrumental performance, as well as artistry; 3) the origin and development of ensemble forms of performance (the formation of kobza duets, trios, ensembles, and chapels); 4) expansion of the repertoire of concerts, including classical instrumental and vocal-choral works. All these directions, in his opinion, were and remain interconnected and dependent on each other ${ }^{15}$.

New performing practices (ensemble and chapel) required the unification of the instrument. Initially, this process involved expanding

14 Sliusarenko T. O. (2016) Bandurne vykonavstvo yak yavyshche natsionalnoi kultury [Bandura Performance as a Phenomenon of National Culture] (PhD Thesis). Kharkiv: I. P. Kotlyarevsky Kharkiv National University of Arts, p. 147.

${ }^{15}$ Cherkaskyi L. M. (2003) Ukrainski narodni muzychni instrumenty [Ukrainian folk musical instruments]. Kyiv: Tekhnika, p. 11. 
its range of sounding. The most common were the two types of bandura and the associated two ways of performing - "Kharkiv" and "Kyiv", then all design searches were carried out in two directions, with mutual influences and borrowings. String diameters, their number, location, and anchoring were improved. Equal temperament made it easier to tune the bandura, but it remained a diatonic instrument ${ }^{16}$. H. Khotkevich became a beginner in improving the bandura; O. Korniievskyi gradually achieved chromatization of the bandura's scale; K. Nimchenko, I. Skliar, and V. Tuzychenko created the improved bandura of the Kyiv model; V. Herasymenko created more than 40 models of bandura of the Lviv and Kharkiv models. Wonderful instruments were produced by the masters of the Chernihiv and Lviv musical instrument factories. V. Kabachok, S. Snihiriova, S. Bashtan, A. Sheptytska, L. Fedorova, L. Dediukh, R. Hrynkiv, and others made their efforts to improve the bandura ${ }^{17}$.

The process of development of academic bandurism on a large scale needed the system of professional education. In this area, it is impossible not to mention the efforts to teach the bandura class at UNTAM Tschaikovsky. The bandura class was founded here in 1950. M. Polotai, V. Kabachok, A. Bobyr, M. Helis taught here the art of bandura. S. V. Bashtan devoted many years to this work. The professor and his students created a productive school for academic bandura performance. Written by S.V. Bashtan, co-authored with A. Omelchenko, the book Bandura School (1984) was the first educational and methodological basis in Ukraine for the education of high-level performers. He carried out fundamental work on the selection, systematization, editing of the repertoire for bandurists of all levels and contributed to their publication in the publishing house "Music Ukraine" (33 issues of "Bandurist's Library", 30 issues of "I would take the bandura", 12 issues of "Bandurist's Repertoire", etc.). In 2011, the Bandura Department was

${ }^{16}$ Panasiuk I. V. (2013) Kafedra bandury NMAU imeni P. I. Chaikovskoho ta peredumovy yii stvorennia [The Department of Bandura UNTAM Tschaikovsky and Prerequisites for its Creation]. Naukovyi visnyk Natsionalnoi muzychnoi akademii Ukrainy imeni P. I. Chaikovskoho [Scientific herald of Tchaikovsky National music academy of Ukraine], no. 107, p. 258.

17 Hrynkiv R. D. (2010) Shliakhy udoskonalennia konstruktsii zvukoriadu bandury [Ways to improve the bandura scale design]. Chasopys Natsionalnoi muzychnoi akademii Ukrainy imeni P. I. Chaikovskoho [Journal of Tchaikovsky national music academy of Ukraine], no. 1(6), pp. 61-67. 
created at the Orchestra Faculty of UNTAM Tschaikovsky comprised of 16 teachers in the specialty, vocal, ensemble and conducting ${ }^{18}$.

Similar traditions of bandura art continue at Kharkiv National University of Arts named after I. P. Kotlyarevsky. For the first time in Kharkiv in 1926, S. P. Drimtsov initiated the foundation of the bandura class at the Music and Drama Institute (since 1934 - Conservatory), which was headed by H. Khotkevych. A professional school of kobza art was founded at this institution, which V. Kabachok, L. Finkelberg, L. Levando, and others graduated from. After H. Khotkevych's death in 1938, the bandura class disappeared and was fully renewed in 1989 by L. Mandziuk at the Department of Folk Instruments. Today at the University there is a bandurist chapel directed by N. Melnyk.

In 1954 a bandura class was opened at the Department of Folk Instruments of Lviv National Musical Academy named after Mykola Lysenko. It was headed by V. Herasymenko, who trained more than 100 professional bandurists during his teaching career. Even today, the department employs professors well-known in Ukraine and far beyond its borders: O. Herasymenko (directs the bandurist quartet), People's Artist of Ukraine, prof. L. Posikra. Since 1962, the Academy has had an ensemble of bandurists ${ }^{19}$. A significant contribution to the development of Kobzar art of the region and its research was made by B. Zheplynskyi, who in the 1950s was exiled to hard labor in Siberia, where he and his brother Roman created a chapel of bandura-convicts. After returning from exile in the time of independence, he headed the Lviv branch of the all-Ukrainian (now - National) Union of kobzars of Ukraine.

Famous artists and scientists such as V. Yesypok, people's artist, professor, N. Broiako, honored artist of Ukraine, professor, P. Chukhrai, T. Yanytskyi, A. Ivanysh (artistic Director of the Bandurist chapel), bandurist virtuoso, people's artist of Ukraine, professor, head of the department of bandura and kobzar art, M. Pidgorbunskyi teach at the

${ }^{18}$ Panasiuk I. V. (2013) Kafedra bandury NMAU imeni P. I. Chaikovskoho ta peredumovy yii stvorennia [The Department of Bandura UNTAM Tschaikovsky and Prerequisites for its Creation]. Naukovyi visnyk Natsionalnoi muzychnoi akademii Ukrainy imeni P. I. Chaikovskoho [Scientific herald of Tchaikovsky National music academy of Ukraine], no. 107, pp. 259-260.

19 Davydov M. A. (2010) Istoriia vykonavstva na narodnykh instrumentakh (Ukrainska akademichna shkola) [History of Performance on Folk Instrument (Ukrainian Academic School)]. Lutsk: Volynska oblasna drukarnia, pp. 114-117, 134-137. 
bandura and kobzar performance department of the Kyiv University of Culture and Art.

The Bandurist Quartet "Herdan" (lead by Professor V. Dutchak) was nominated at the 3rd All-Ukrainian Open Festival-Competition of Performers on Folk Instruments "Merezhyvo" ("Lace") (April 23-26, 2017) they took the first place and got the title of laureates. This showed an excellent level of teaching the course for bandurists of the academic genre at the Department of Folk Instruments at Vasyl Stefanyk Precarpathian National University.

Professor N. Morozevych initiated a special bandura class at the Department of Folk Instruments at The Odessa National A. V. Nezhdanova Academy of Music. Simultaneously N. Morozevych leads the trio of bandurists "Malvy" ("Mallows") at Odessa's Philharmonic Theatre.

A professional bandura school has also appeared in Dnipropetrovsk region. Lidiia Vorinova played a great role in it. She created the ensemble "Charivnytsi" ("Sorceresses"), achieved the opening of the bandura class at Dnipro Conservatory, together with her students held nine concerts of the festival "Dzveni, bandura!" ("Ring, bandura!") ${ }^{20}$.

I. Kuchuhura-Kuchurenko, V. Yemets, V. Kabachok, H. Khotkevich (the first half of XX century), S. Bashtan, V. Herasymenko, N. Broiako, O. Varvyk, O. Herasymenko, V. Dutchak, L. Mandziuk, N. Morozevych, L. Posikra, R. Voit, R. Hryniv, N. Melnyk, K. Novytskyi, L. Fedorova (the end of XX-beginning of XXI century.) and others became wellknown far beyond the borders of Ukraine for their academic performance on the bandura. This brought worldwide fame to Ukrainian musicians, which contributed to the spread of our folk culture abroad.

Among the active groups of our country of the modern period, the following should be mentioned: the Bandurist chapel "Carpaty" ("Carpathians") of the Ukrainian society of the blind, in which $70 \%$ of bandurists are visually impaired; folk Bandurist chapel "Chervona Kalyna" ("Guelder rose") "Vyshyvanochka" ("Embroidery"), "Zorinytsia" ("Daw"), "Dzvinochok" ("Bell") and "Halychanka" (Lviv); Bandurist chapel "Zacharovana Desna" ("Enchanted Desna") of Lev Revutskyi Chernihiv music school; Ivano-Frankivsk Bandurist Chapel;

${ }^{20}$ Cherneta T. O. (2009) Vydatni muzykanty Dnipropetrovshchyny. Lidiia Vorina [Outstanding Musicians of Dnipropetrovsk Region. Lidiia Vorina]. Dnipropetrovsk: Yurii Serdiuk. 
Bandurist trio "Verbena" (Cherkasy), Bandurist Quartet "Lvivianka" (Lviv), duet "Bandurna rozmova" ("The talk of banduras") (Lviv), Bandurist trio "Malvy" ("Mallows") (Odessa), Bandurist sextet "Charivnytsi" ("Sorceresses") (Dnipro), trio "Oriana" (Ternopil), national honored Bandurist Chapel of Ukraine named after H. I. Maiborody, Strusiv honored Bandurist chapel of Ukraine "Kobzar", Bandurist chapel named after T. H. Shevchenko from the USA, Canadian Bandurist chapel, Cherkasy municipal Bandurist chapel, Municipal Bandurist chapel of Ivano-Frankivsk, children's ensembles "Yahilka", "Hamaliia "(Lviv) "Little falcons" (Chernihiv), etc.).

\section{The Reproductive Course of Kobzardom}

After the Second world war (1939-1945), the old "conservative" people's household branch of Kobzardom gradually began to revive. H. Tkachenko put a lot of effort into this process. He worked at fundamental research of kobzardom, laid the foundations for the revival of the traditional bandura performance, the skills of which he adopted from P. Drevchenko and passed on to his students: M. Budnyk, M. Tovkail, V. Mishalov, and other famous kobzars.

With the beginning of the democratization of Soviet society, the attention to the ancient folk traditions increased. Kobzar art aroused the interest of the younger generation. The interest turned into a whole movement. L. Ivannikova described the emotional state of supporters of this movement in the late 1980s: "... Everyone was anxious about the revival of the idea of kobzardom. It was not only about singing and playing, not only performing in concert halls, but also on the streets, in parks, even in markets, and at the same time about making (and later reconstructing) ancient traditional instruments such as the bandura, kobza, lyre, and even gusli. All this required turning to scientific literature and archival sources, to expedition work, i.e., a serious study of a unique phenomenon in the world culture. So out of the romanticallyoriented amateurs, the following extraordinary figures in Ukrainian science appeared: V. Kushpet (bandurist, torbanist, kobzist, master of instruments), author of the monograph "Eldership. Wandering Musicians in Ukraine (19th - early 20th centuries)" (Kyiv, 2007), K. Cheremsky, who studied the archives of the Department of Home Affairs-NKVD and wrote several monographs on the history of the destruction of kobzardom in the XXth century and its revival in the post-Soviet times ("Return of Traditions. From the History of the Destruction of Kobzardom" 
(Kharkiv, 1999), "The Way of Customs" (Kharkiv, 2002)) and others. This cohort also includes M. Khai, a Ukrainian instrumental musician well-known in Ukraine and abroad, author of numerous articles and monographs on this subject, Doctor of Arts and a practicing lyricist ${ }^{21}$, also known as lyricist Stefan.

The result of this movement was the creation of the all-Ukrainian Kobzar Union (1990). Kobzars' congresses, festivals of Kobzar art, competitions, concerts, and anniversary evenings were held thanks to the activities of V. Lytvyn, V. Horbatiuk, and V. Yesypok. M. Budnyk organized the Kyiv-Irpinsk Kobzar workshop, around which the conscious Ukrainian youth gathered, passionate about the idea of reviving the national culture: students, scientists, musicians, and music masters. On the ancient principles of the Kobzar brotherhood, young boys -made authentic samples of kobzas, banduras, hurdy-gurdies, torbans, gusli, hudoks, and violins. At the same time, they learn to play these instruments and organize exhibitions of their products. For many of them, kobzardom became a professional activity. From the group performances that had been practiced earlier, they moved to kobza performances in crowded places: on streets, squares, underpasses, near churches, and cathedrals. According to the Kobzar tradition, they pray and confess in the Church of the Intercession, consecrate their instruments, celebrate religious holidays, and adhere to the Orthodox fast $^{22}$.

Based on the ancient traditions of the Kobzar brotherhood, there are three workshops in Ukraine today: Kyiv kobzars (M. Tovkailo), Lviv lyrnists (M. Khay), and Kharkiv kobzars (K. Cheremskyi). Their main activity is focused on recreating the Kobzar tradition of making musical instruments, as well as performing authentic Kobzar repertoire on them ${ }^{23}$.

${ }^{21}$ Ivannikova L. (2016) Khai M. Mykola Budnyk i kobzarstvo [Khai M. Mykola Budnyk and kobzardom] (Review) . Studii mystetstvoznavchi [Art History Studios], no. 1, pp. 110-111.

22 Cherkaskyi L. M. (2003) Ukrainski narodni muzychni instrumenty [Ukrainian folk musical instruments]. Kyiv: Tekhnika, p. 163.

23 Chaika S. V., Chaika M. M. (2012) Kobzarstvo - diievyi chynnyk zberezhennia tradytsii dukhovnoho zhyttia natsii [Kobzardom is an effective factor in preserving the traditions of the spiritual life of the nation]. Pedahohichna osvita: teoriia i praktyka [Teacher education: theory and practice], vol. 12, p. 444. 
Today there are workshops for the production of traditional musical instruments in Kyiv, Lviv, Kharkiv and Poltava region. With the support of local creative associations, they carry out their activities privately and serve as true centers of the revival of the folk music tradition. The workshops train specialists in the production of instruments and performers. Kobzar camp, founded by Yu. Fedynskyi in a family house in the village of Kriachkivka is indicative in this respect. They organize tutorials on making musical instruments during cultural events, festivals (in particular, "Kobzar Triitsa" ("Kobzar Trinity"), "Kobzar-lyric Pokrova", "Kraiina Mrii" ("Dreamland"), "Mazepa-fest", etc.), concerts, etc. The project of the Mobile Kobzar Workshop, which is carried out by the Kharkiv Kobza Workshop in educational institutions of the region and involves direct participation in mastering the tools of a wide range of pupils, students, and youth communities, is quite promising. Since 2008, the Kyiv workshop has been holding the "Kobzar Triitsia" ("Kobzar Trinity") festival, which includes tutorials in making and playing musical instruments.

According to K. Cheremskyi, analyzing the causes of this movement as a phenomenon of spiritual life, participation in the activity of the kobzar workshop is an internal spiritual call, which "can hardly be understood from rational positions, because authentic kobzardom is a peculiar state of mind, a response to the need for a constant sense of depths of eternity, the voice of the ancestors, proven over centuries source of strength, spiritual and creative inspiration, effective psychoregulation and healing, our reliable protection for the future" ${ }^{24}$.

There are examples of the emergence of new centers whose activities fall under the name of new Kobzar schools. It refers to Stritivka Higher Pedagogical School of Kobza Art. It was created in 1989 on the initiative of V. Lytvyn, B. Oliinyk, and O. Berdnyk. Since 2014, it became "Stritivka Pedagogical College of Kobza Art". At the moment, the College reports on the training of more than 250 bandurists-singers.

Representatives of the reproductive movement from the end of the 1980s began to practice singing and playing the Kobzar-lyric authentic music on the streets and at the holy places (M. Budnyk, V. Kushpet, M. Khai, etc.). The copying of the "aging" timbre and the "infirm" intonation became the sign of this movement. Another sign of the revival

${ }^{24}$ Cherkaskyi L. M. (2003) Ukrainski narodni muzychni instrumenty [Ukrainian folk musical instruments]. Kyiv: Tekhnika, p. 4. 
of authenticity is the repertoire. It includes restoring old transcriptions, archival material, real kobzar dumas, historical songs that were performed by blind singers of the second half of the XIX - early XX century. This repertoire includes real pearls of Kobzar art: dumas "Crying of the Slave," "About Samiilo Kishka" (written by lyrist I. Scubii in the village of Leliukhivka, Poltava region, O. Slastion, trans. by F. Kolessa), variant of duma "About Marusia-Bohuslavka" (taken over using auditory method by M. Budnyk from H. Tkachenko), dumas "About the Escape of Three Brothers from the City of Azov" (reconstructed by the auditory method (by H. Tkachenko)) [Kolesya registered it under the name "About Azov brothers"], "About Khvedor the Unfortunate-Rootless. Historical songs in their performance include such works as "Maksym, Cossack, Zalizniak", psalms "There is no Truth in the World" (taken in a "live way", orally from H. Tkachenko in the 1960s), "About Lebedenko" (recorded by P. Barylchenko in the village of Nyzhnia Pysarivka (Kharkiv region) D. Yavornytskyi), cants "Oi, across the Bridge, Bridge" (recorded by M. Khai from P. Zhadan in the village of Chernechchyna (Kharkiv region)), "Archangel Michael" (reconstructed from the hand-written collections of the National Museum in Lviv (M. Vozniak's archive)) and "About Pochaiiv God Mother", the satirical song "The Wedding of the Hare" (taken orally from the last blind lyrist I. Smyk (I. Vlasiuk, Zaliuttia (Volyn)).

In their performances, the masters of this movement use authentic musical instruments: the hurdy-gurdy (M. Khai, V. Shevchuk, Yu. Kondratenko, etc.), the old-world bandura (M. Tovkailo, V. Kyrylych, N. Cherkas, etc.), the so-called "kobza of O. Veresai" (T. Kompanichenko, A. Seletskyi, Yu. Fedynskyi, etc.).

In 1999, the All-Ukrainian Union of Kobzars was reorganized from the public organization of kobzars (1995 creation) and got the status of the National public organization. It concentrated in its ranks all the manifestations of kobzardom of Ukraine. Thanks to the work of the Union, 10 regional and 3 city branches of the National Union of Kobzars of Ukraine (NUKU) were organized. In general, the organization has 450 bandurists and kobzars of different age categories. The head of the NUKU is V. M. Yesypok - people's artist of Ukraine, Professor. One of the main tasks of the Union is to establish a systematic nature of collecting and recording Kobzar heritage, audio and video recordings of the performing style of kobzars who are more than 60 years old. The Union released 5 collections of the Bandurist's repertoire "Hey, hit the strings, kobzari" (compiled by V. Yesypok), "Etudes for bandura" 
(compiled by L. Mandziuk), "Our Duma" (compiled by Halii-Muravska), and others.

The same artistic Union initiated and held the international festival, I and II competitions of Kobzar art named after H. Kytastyi. NUKU promotes and participates in the traditional festivals of Kobzar art "To the silver sound of banduras" in the city of Mykolaiv, the festival of kobza art named after K. Misevych in Rivne region, Yu. Synhalevych in Lviv region, V. Perepeliuk in Vinnytsia region, "Bandura is ringing in the city of Frankiv" - in Ivano-Frankivsk, the International festival of Bandurist ensembles in Dnipropetrovsk, the festival of Kobzar art "Ring, bandura, in Cossacks' land", Dnipro. To date, five congresses of kobzars of Ukraine have been held (the last one was in December 2014). We also note the organization of ethnic festivals "Kobzar-lyric Intercession": "Lyric Intercession in Drohobych" (2012), " Kobzar-lyric Intercession in Kyiv" (2013, 2014, 2015, 2016), "Lyric Intercession in Rivne" (2014, 2015, 2016). To attract young people to the ancient music art, the All-Ukrainian competitions were launched: the Competition for Young Bandurists named after V. Kabachok in Poltava region, All-Ukrainian Competition for Young Bandurists "Volyn Kobzaryk", Cherkasy Children's Competition for Young Bandurists "Kobzarevi Dzherela" ("Kobzar sources") and more.

The philosophy of the kobzar tradition includes not only singing and music but also conversation with the listener, moralizing on the theme of historical truth, nature of behavior, respect for others, love of God, etc., where they sound and are interwoven in the comparative aspect of the problems of the past and present (national concept "historical memory" Cossack victory, Sich archery, UPA heroism, famine, political exposure, ridicule of the tsar, the Soviet Union and present aggression of Russia, etc.).

Many artists have been brought up in a fairly widespread movement to revive Kobza art, and they have practically linked their professional fate to the reproductive stream. But even among them, some bands and performers have earned the love and popularity of the general public with their talent. Nowadays, Vasyl Zhdankin is considered to be the cult singer, bard, kobzar, performer of folklore texts, singing poetry and author song. Albums - "Thresholds are beating" (1991, republished in 2006), "Confession" (2006). The artist's repertoire of folk music consists of Cossack, Patriotic texts of an epic nature and songs on religious themes, which are performed to the accompaniment of a six-string kobza ("Oi, the evening dawn has risen", "Song of Polish immigrants", "What happened to us from the beginning of the world", "Oi, the Eagle Owl sat 
on the Tomb", "the Legend of Noah", etc.). The singer has a special, magnificent bass timbre, and he strongly professes Eastern Orthodox rite. $\mathrm{He}$ is considered to be one of the last kobzars of our time.

Accompanied by the veresaivska kobza, the old-world bandura, and hurdy-gurdy, Eduard Drach performs as a performer and reconstructor of the traditional Kobzar-lyric repertoire, which belongs to the community of the "Kyiv Kobzar workshop". In addition to the author's texts, he sings and plays folk material, i.e. "Zaporizhzhia songs", Cossack psalms, chivalric songs, slave lamentation, prayerful songs, devout psalms and cants, spiritual and secular lyrics. Another outstanding personality is Volodymyr Yesypok. He is a Ukrainian bandura singer (bass), People's Artist of Ukraine (2007), Professor, Head of the National Kobzars Union of Ukraine. His repertoire: duma "About the Cossack Bandurist", "About Cossack Holota", historical "From Poltava battle", "Maksym Cossack Zalizniak", chumatski, family and household, lyrical, comic songs. Sashko Lirnyk (Oleksandr Vlasiuk) became widely known as a storyteller and lyrist who plays such folk musical instruments as the hurdy-gurdy, kobza, and bandura. In 2003, the disk "Tales of lyrist Sashko for adults and children" was considered to be the best album in Ukraine (the results of a survey by the magazine "Politics and culture"). Performer Viktor Pashnyk (pseudo - Shkrum, 1980; studied at Stritivka Kobzar School) seeks to fully stylize his life under the kobzar's wandering philosophy, so he travels the world and sings to the kobza in the open air. His album "Kobzar Shkrum" (2009) was recorded accompanied by a bandura. There are the following Ukrainian folk songs in the repertoire: "How I went home from Debrechyn", "Gray pussycat", "The girl went through the meadows", "My mother beat me".

One of the famous students of professor V. Herasymenko is a bandurist Taras Lazurkevych. Joint work with his teacher allowed him to take part in the decoding of phonorecords of old dumas, psalms, historical songs, and instrumental music. He launched an active work in the reconstruction of ancient song texts of kobza art. His repertoire includes Ukrainian folk historical dumas "About Cossack Holota", "About the Three Brothers from Azov" and "About Marusia Bohuslavka". Together with another student of V. Herasymenko, Oleh Sozanskyi, he founded the duet "Bandurna rozmova" ("The talk of banduras"). Also, the performer, together with his teacher and other bandurists created the international fund "Kobzar". The main objectives of the organization are comprehensive assistance and contribution to the development of Kobzar art. 
The band "Chorea Kozatska" (2005) is particularly noteworthy. It is a Kyiv music group that performs an ancient Ukrainian melos of different eras: the Middle Ages, Renaissance, Baroque, Classicism, Romanticism and individual works of the XX century. The band performs songs that have been found in archives, manuscripts, and printed collections. The repertoire covers the following genres: dumas, historical, heroic and rebel songs, hymns, psalms, cants, and spiritual concerts. Albums of the group: "Carmina Sarmatica" (2009), "Knight Thrilled with Courage (Concert in Lutsk castle)“" (2009), collaboration with "Guliaigorod" "Terra cosaccorum" (2010) and "Spiritual Feast" (2013). The team consists of several professional bandurists and lyrists. The leader of the group T. Kompanichenko plays the "bandura of Ostap Veresai" (according to the description of M. Lysenko), lyra, old-world bandura.

In addition to solo practice and work in "Chorea Kozatska", T. Kompanichenko sings in the international choir "Academy of traditions". The institution consists of singers and musicians from the countries of Central and Eastern Europe. Meetings take place not only in the form of concerts but also seminars on ancient European music are held. In addition to singing in Latin, German, French, Estonian, Lithuanian, Belarussian, Russian, works in Church Slavonic (with Kyiv phonetics) and ancient Ukrainian-Russian languages are performed and restored. Also, T. Kompanichenko is a member of the group "The Carpathians" (2003) (the leader of the group - Yu. Fedynskyi is an American of Ukrainian descent, artist-polyinstrumentalist). Most of the members of the band were previously engaged in authentic music, which strengthens the main credo of the group - to make ethnocultural creativity. The band performs mostly forgotten or completely unknown to the public Ukrainian folk songs collected during folklore expeditions throughout Ukraine (Carpathian kolomyiky, Polesia vesnianky, wedding marches of the Steppe region in combination with elements of rock, jazz, avant-garde, and so on). During the group's performances, the combination of traditional instruments on one stage, such as the bandura, tsymbaly, kobza, pipes, and hurdy-gurdy, is characteristic.

Band "Shpyliasti Kobzari" resorts to a creative combination of Ukrainian folk melodies to the accompaniment of the bandura with contemporary music styles. This is a group of six young bandurists who perform original songs, instrumental works, cover versions of world hits and Ukrainian folk songs in a modern format in the style of "musical cartoon" ("Banduryste, Orle Syvyi!" ("Bandurist, Eagle Dove!"), "Marusia", "Shchedryk", " Oi, sluzhyv ya u pana..." ("Oh, I served at the 
lord's ...") and the like). The initiator of the band is a young bandurist Ya. Dzhus, who also created a project for the development of the bandura brand "Bandura style", which is aimed at popularizing the Ukrainian musical instrument and Ukrainian musical culture as part of the modern art space. The achievements of the project include the organization of the Scene of modern bandura at the Ethno festival "Kraina Mrii" ("Dreamland"), the release of the music collection "12 instrumental works for bandura", etc.

\section{CONCLUSIONS}

Kobzardom as a cultural phenomenon, along with a set of folk musical instruments inherent in the creativity of kobzars, bandurists, lyrists, is the property of Ukrainian art, which has contributed to the education of the masses for centuries. It attracted the attention of scientists in the second half of the XIX - early XX century, which allowed, although at the final stage of authentic development, to study it in various research perspectives. For objective historical, socio-cultural and political reasons, in the first half of the twentieth century, traditional kobzardom was destroyed, but the academic bandura performance supported by the state received an extraordinary development. It significantly deviated from the authentic sources of kobzardom, despite this, it was popular with its people and brought them world recognition, allowed them to prepare a whole cohort of bandurists-virtuosos and experts, expand their repertoire, improve folk musical instruments, and diversify their concert activities. The revival of authentic kobzar art today is a symbol of the Renaissance of the Ukrainian national spirit. And this is seen as a positive factor in its reproductive potential. Undoubtedly, the actual folklore heritage in this course is more than in academic performance, which is the answer to the question posed in the aim of this study. But at the same time, we would like to emphasize that both directions of kobzar culture are the property of modern Ukrainian culture, and the help from the state can become a key factor for overcoming differences between them, which would play an important role in patriotic education of young people.

\section{SUMMARY}

In the second half of the nineteenth century, interest in traditional musical culture increased significantly and the researchers drew attention to such a folklore phenomenon as a kobzardom, which later became the symbol of Ukrainianity in the world. 
The article examines the development of kobzar art in the historical musicological aspect, determines the influence of the kobzar heritage of the Ukrainian people on the present state and prospects for its further development. The phenomenon of kobzar art (along with accompanying national musical instruments), as the property of Ukrainian culture, is determined. The revival of authentic kobzar art today is a symbol of the era of the renovation of the Ukrainian national spirit. And this is seen as a positive factor in reproductive direction.

Today there are some contradictions between the supporters of the authentic kobzas and the representatives of academic bandura performance. They are based on the degree of proximity of each artistic direction to the true sources of this unique musical and social phenomenon of Ukrainian culture. The problem becomes acute on the background of the prospects for further development of this genre. However, the contradictions between professional and amateur performing schools have only one consensus on this issue - this phenomenon and the objects of a particular dispute ("kobza, lyre, bandura") encode the creative mental code of Ukrainians, old traditions and the history of the kobza process.

From objective historical, socio-cultural and political reasons in the first half of the twentieth century the traditional kobzar art was destroyed, and the state-sponsored academic banda's execution got considerably developed. In spite of this, it departed significantly from authentic sources of kobzars, enjoyed popularity among people and brought it worldwide recognition, made it possible to prepare a whole cohort of virtuoso bandurists, specialists in their work, to expand the repertoire, to improve folk musical instruments, to diversify concert activities.

The aim of work is to give analysis for the influence of folk music on the modern Ukrainian Cossack art and prospects of its development, this represents a novelty in terms of the problem. Methods: historical musicological analysis and synthesis.

Kobzardom phenomenon in Ukraine is unique, it has existed for centuries. For some objective reasons at a certain historical period academic bandura performance was dominated, this departed from authentic sources of kobzardom tradition. At the time of the independence the revival of authentic (reproductive) kobzardom flow began, which is, in our opinion, a positive phenomenon. 
Today, both currents of art are the property of the Ukrainian culture, which requires an effective state aid in the form of extraordinary importance in the patriotic education of youth.

\section{REFERENCES}

1. Bogdanova O. V. (2002) Lirnytska tradytsiia $v$ konteksti ukrainskoi dukhovnoi kultury [Lyric tradition in the context of Ukrainian spiritual culture] (PhD Thesis). Kyiv: Ukrainian National Tchaikovsky Academy of Music.

2. Bozhko M. O., Pasko M. V. (2015) Dukhovni nastavnyky narodu: kobzarstvo v Ukraini: Bibliografichnyi narys [Spiritual Mentors of the People: Kobzardom in Ukraine: A Bibliographical Essay]. Kyiv: Centralized library system of the Shevchenkivskyi district of Kyiv. (in Ukrainian)

3. Chaika S. V., Chaika M. M. (2012) Kobzarstvo - diievyi chynnyk zberezhennia tradytsii dukhovnoho zhyttia natsii [Kobzardom is an effective factor in preserving the traditions of the spiritual life of the nation]. Pedahohichna osvita: teoriia i praktyka [Teacher education: theory and practice], vol. 12, pp. 439-446.

4. Cheremskyi K. (1999) Povernennia tradytsii. $Z$ istorii nyshchennia kobzarstva [Return of traditions. From the History of the Destruction of Kobzardom]. Kharkiv: Les Kurbas Centre. (in Ukrainian)

5. Cherkaskyi L. M. (2003) Ukrainski narodni muzychni instrumenty [Ukrainian folk musical instruments]. Kyiv: Tekhnika. (in Ukrainian)

6. Cherneta T. O. (2009) Vydatni muzykanty Dnipropetrovshchyny. Lidiia Vorina [Outstanding Musicians of Dnipropetrovsk Region. Lidiia Vorina]. Dnipropetrovsk: Yurii Serdiuk. (in Ukrainian)

7. Davydov M. A. (2010) Istoriia vykonavstva na narodnykh instrumentakh (Ukrainska akademichna shkola) [History of Performance on Folk Instrument (Ukrainian Academic School)]. Lutsk: Volynska oblasna drukarnia. (in Ukrainian)

8. Dutchak V. G. (2010) Mykhailo Teliha: postat myttsia v konteksti epokhy [Mykhailo Teliga: The Figure of the Artist in the Context of the Era]. Naukovyi visnyk Natsionalnoi muzychnoi akademii Ukrainy imeni P. I. Chaikovskoho [Scientific herald of Tchaikovsky National music academy of Ukraine], vol. 91, pp. 249-261.

9. Hrynkiv R. D. (2010) Shliakhy udoskonalennia konstruktsii zvukoriadu bandury [Ways to improve the bandura scale design]. Chasopys Natsionalnoi muzychnoi akademii Ukrainy imeni 
P. I. Chaikovskoho [Journal of Tchaikovsky national music academy of Ukraine], vol. 1(6), pp. 61-67.

10. Ivannikova L. (2016) Khai M. Mykola Budnyk i kobzarstvo [Khai M. Mykola Budnyk and kobzardom] (Review) . Studii mystetstvoznavchi [Art History Studios], no. 1, pp. 110-113.

11. Khai M. (2007) Muzychno-instrumentalna kultura ukraintsiv (folklorna tradytsiia) [Musical-Instrumental Culture of Ukrainians (Folk Tradition)]. Kyiv; Drogobych: Kolo. (in Ukrainian)

12. Khotkevych H. (2002) Muzychni instrumenty ukrainskoho narodu [Musical instruments of the Ukrainian people] (Reprint 1930). Kharkiv: DVU. (in Ukrainian)

13. Kolessa F. (1969) Melodii ukrainskykh narodnykh dum [Melodies of Ukrainian Folk Dumas]. Kyiv: Naukova dumka. (in Ukrainian)

14. Panasiuk I. V. (2008) Tvorcha diyalinisti S. V. Bashtana $v$ kontecsti stanovlenya Kyivskoi shkoly akademichnogo bandurnogo vykonavstva [The Creative Activity S.V. Bashtan in the Context of the Establishment of the Kyiv School of Academic Bandura Performance] (PhD Thesis). Kyiv: Ukrainian National Tchaikovsky Academy of Music.

15.Panasiuk I. V. (2013) Kafedra bandury NMAU imeni P. I. Chaikovskoho ta peredumovy yii stvorennia [The Department of Bandura UNTAM Tschaikovsky and Prerequisites for its Creation]. Naukovyi visnyk Natsionalnoi muzychnoi akademii Ukrainy imeni P. I. Chaikovskoho [Scientific herald of Tchaikovsky National music academy of Ukraine], vol. 107, pp. 254-267.

16. Sliusarenko T. O. (2016) Bandurne vykonavstvo yak yavyshche natsionalnoi kultury [Bandura Performance as a Phenomenon of National Culture] (PhD Thesis). Kharkiv: I. P. Kotlyarevsky Kharkiv National University of Arts.

17. Suprun-Iaremko N. O. (2010) Muzykoznavchi pratsi [Musicological works]. Rivne: O. Zen. (in Ukrainian)

18. Trembitskiy A. M. (2007) Relighiyini motyvy ukrainskyh "nezryachih" mandryvnyh spivtsiv [Religious Motives of Ukrainian "Blind" Wandering Bards]. Narodna tvorchist ta etnohrafiia [Folk creativity and ethnography], no. 6, pp. 54-61.

19. Trembitskyi A. M. (2008) Arho nosiiv ukrainskoho "nezriachoho" epichnoho mandrivnoho mystetstva: stan naukovoi rozrobky problemy [The Cant of the Bards of the Ukrainian "Blind" Wandering Epic Art: State of Scientific Development of the Problem]. Ivan Ohiienko $i$ 
suchasna nauka ta osvita [Ivan Ohiienko and Modern Science and Education], vol. 5, pp. 110-148.

20. Vavryk O. (2006) Kobzarski shkoly v Ukraini [Kobzar Schools in Ukraine]. Ternopil: Zbruch. (in Ukrainian)

21. Yezhel Yu. (2017) Zrobysh banduru - vizmemo: Yak "posviachuiut" u suchasnykh kobzariv [You make the bandura - we will take you: how modern bandurists "are consecrated"]. Ukraina Moloda [Ukraine Young], 25 June, p. 13.

Information about the author:

Furdychko Andrii, orcid.org/0000-0002-2963-9794 Doctor of Arts, Associate Professor

Kyiv University of Culture 20, Chygoryna Str., Kyiv, 01601, Ukraine 
DOI https://doi.org/10.36059/978-966-397-197-1/111-128

\section{THE THEATER CONCEPT IN MODERN CULTURAL SPACE}

\section{Ishchenko Yevhenii}

\section{INTRODUCTION}

From the first steps, humanity perceives the space in terms of their vital interests as forms of being, appealing to the perception, experiences, comprehension of the practice of each individual. Historically, the image of space has evolved at the same time as the formation of culture, which is why this category is the most important characteristic of being human ${ }^{1}$.

At all times, the theater was perceived as the most democratic, open to the society at large and accessible to the lower classes, a form of art unlike literature, which has an "elitist" character and required a higher level of development of intellectual abilities in humans. However, theatre in the minds of speakers of different languages is not only a theatre in the narrow sense of the word but also thought in a wide field of cultural, sociological, political, philosophical and art knowledge and is a rather contradictory concept that needs broad interpretation. ${ }^{2}{ }^{3}$.

Domestic and ceremonial entertainment, folk spectacles played a huge role in the development of the cultural polysystem in general and the theatre in particular. Not only did they make a huge contribution to the development of the theatre, but they also served as a basis for the

${ }^{1}$ Orlova E. V. (2009). Fenomen teatralnogo prostranstva: kulturfilosofskii analiz [The phenomenon of theatrical space: cultural philosophical analysis]. Izvestiia Saratovskogo universiteta. Seriia Filosofiia. Psikhologiia. Pedagogika, vol. 9, no. 3, p. 37.

${ }^{2}$ Kalinina S. A. (2011). Leksiko-frazeologicheskaia reprezentatciia kontcepta "Teatr" v russkoi i angliiskoi lingvokulturakh [Lexical and phraseological representation of the concept of "Theater" in Russian and English linguistic cultures]. Teoriia i praktika obshchestvennogo razvitiia, no 8, p. 374.

3 Adrianova T. O. (2014). Teatr kak sotciokulturnyi fenomen [Theater as a sociocultural phenomenon]. Vestnik Orenburgskogo gosudarstvennogo universiteta, no. 168 , pp. $82-85$. 
skill of future performers ${ }^{4}$. At the same time, the process of preparing the carriers of the cultural polysystem - spectators to understand the theatrical action as a mechanism of self-identification of the Self, the Other and the culture as a whole, in relation to which it became form and content at the same time, began. On the one hand, they exist within a culture relevant to themselves, stratified by its norms; on the other, they are expressions of culture, in fact, a culture that is determined by a certain discursive act.

In the philosophical, cultural, linguistic and other scientific fields there is a strong interest in understanding the concept of theatre. Extrapolation of the philosophical concept of theatre into the science of theatre initiates the development of theatre theory at the modern scientific level. Different levels of theatre concept are manifested in their entirety through the prism of the philosophical tradition, in particular, of aesthetic knowledge and the study of artistic tradition aimed at the understanding theatre as $\operatorname{such}^{5}$.

At the same time, the conceptualization of the concept is inherently integrative, because it is impossible to determine where the realm of cultural studies, sociology, art studies and so on ends.

The purpose of the article is to identify the concept of theatre and to determine its role in theatrical studies on the basis of the analysis of theoretical and practical material of the theatre arts.

A number of authors have been involved in the research of outlined issues, in particular, S. O. Arutiunov, M. M. Bakhtin, Yu. V. Bromlei, M. M. Hromyko, O. Ya. Hurevych， I. O. Yedoshyna， M. M. Zabylin, L. Ye. Kalmykova, V. V. Kolesov, D. S. Likhachov, M. O. Nekrasova, O. F. Nekrylova, O. M. Panchenko, V. Ya. Propp, O. M. Pypin, Yu. S. Stepanov, O. S. Khomiakov, M. O. Khrenova and others. Theater, its forms and social functions were investigated by T. M. Akimova, O. I. Biletskyi， P. G. Bogatyrov， I. M. Veletska， V. M. Vsevolodskyi-

${ }^{4}$ Batnasangiin S. (2009). Religiozno-istoricheskie nachala mongolskogo teatra [Religious and historical beginnings of the Mongolian theater]. Vestnik Tomskogo gosudarstvennogo universiteta, no. 320, p. 75 .

5 Azeeva I. V. (2008). Kontcept teatra i traditciia filosofskogo znaniia ( $\mathrm{k}$ probleme formirovaniia teorii teatra $\mathrm{v} X X$ veke) [The concept of the theater and the tradition of philosophical knowledge (on the problem of the formation of the theory of theater in the twentieth century)]. Izvestiia Rossiiskogo gosudarstvennogo pedagogicheskogo universiteta imeni A. I. Gertcena, no 11, p. 85. 
Hernhross, V. E. Husev, L. M. Ivlieva, V. D. Kuzmin, N. I. Savushkin, O. F. Nekrylova and others.

\section{The Scientific Conception of Theater and its Concept: \\ Characteristics, Features, Understanding}

The human activity in the development and processing of the outside world directly depends on person's perceiving spatial aspects, which is represented in forms of culture, one of which is language as a sign system. At the same time, there is a projection in the forms of cultural being, one of which is theatre as a certain medium for meaningful living. Thus, the spatial predetermination of human activity as social communication is of particular importance in theatrical creativity. Since ancient times, people have tried to learn, realize and expand their living space through play: wearing ritual masks (and the theatre is known to emerge during the gradual secularization of ceremonies and rituals), everyone could "tame" the incomprehensible, and therefore hostile reality ${ }^{6}$, adaptated it themselves, and thus "tamed".

The understanding of theatrical space as a theatrical culture has emerged rather than within the limits of theatrical, art or cultural studies, but within the limits of criticism and journalism. Often in critical articles about theatre, the term "theatre space" is used to mean the conditional totality of all phenomena in theatrical life: a series of performances, tours, performances by theatre figures, critics, conferences, educational institutions, etc.?

Our position is that the scientific definition of theatre is not identical to its concept. This is due to the fact that the basis of the concept is a category of meaning, that is, the concept involves reference to the theatre as its category. The scientific concept views theatre as a form of art, the essence of which is the artistic reflection of life through dramatic action, which is usually unfolded in front of the viewer. Not identical, the scientific concept of theatre and its concept have both a common part and separate components. For example, such an aspect of theatre art as a genre will belong to both the concept and the concept. The significance

${ }^{6}$ Orlova E. V. (2009). Fenomen teatralnogo prostranstva: kulturfilosofskii analiz [The phenomenon of theatrical space: cultural philosophical analysis]. Izvestiia Saratovskogo universiteta. Seriia Filosofiia. Psikhologiia. Pedagogika, vol. 9, no. 3, p. 37.

${ }^{7}$ Vozgrivtceva K. I. (2005). Teatralnoe prostranstvo: kulturologicheskii aspekt. Izvestiia Uralskogo gosudarstvennogo universiteta, no. 35, p. 58. 
of the concept is that it has something that cannot be inherent in a concept that deals with formative characteristics, namely, meaning. Thus, conceptualization in the cultural space is the sense-distinguishing boundary of theatrical research aimed at internalizing the purely artistic representation of the phenomenon of theatre into the paradigm of integrated and complex research.

In the process of analyzing the theatrical forms' origin, we naturally observe their indivisibility, unity with the play (playing with personal $I$, playing $I$ with another, playing the Other, according to current discursive practices, with culture, and through it - with myself, etc.). Indicative in this context is the religious mystery of the Tsam, which was spread in Tibet and later became popular in Mongolia. In essence, this is an esoteric religious rite, a mystery that aims not only to enlighten the audience, to remind them of the transience of their being but also to enter into a certain mystical union with the world, with a further doubling of joy and happiness ${ }^{8}$.

The above proves that theatrical art cannot develop beyond historical time and space, that it is discursive by its very nature, being represented as a simulation of ontological reality, it captures the axiological significance of its phenomena. The latter can be explained by the fact that the theatrical life is unfolding within the limits of socio-historical evolution. Theatre is always an expression of the thoughts, the atmosphere of the world public, progressive ideas presented in the artistic version, which, however, do not lose their significance or, on the contrary, lose: to give them public appreciation. Theatrical processing of the accumulated social experience, its transformation into the object of aesthetic, artistic, creative reflection takes place within certain spatial limits, which, in turn, produces the presence of spatial characteristics in it ${ }^{9}$.

On the example of the aforementioned, it clearly shows the cultural conditionality of the theatrical action, its discursiveness. In performing this performance, the actor-lama represented the leading Buddhist philosophical and religious principles. Thus, the content of culture was

${ }^{8}$ Batnasangiin S. (2009). Religiozno-istoricheskie nachala mongolskogo teatra [Religious and historical beginnings of the Mongolian theater]. Vestnik Tomskogo gosudarstvennogo universiteta, no. 320, p.72.

${ }^{9}$ Orlova E. V. (2009). Fenomen teatralnogo prostranstva: kulturfilosofskii analiz [The phenomenon of theatrical space: cultural philosophical analysis]. Izvestiia Saratovskogo universiteta. Seriia Filosofiia. Psikhologiia. Pedagogika, vol. 9, no. 3, p. 37. 
actualized in its forms: through the complex language of plastic, which, in turn, was its (culture) element. It is natural that the performer of such a performance needed to have strong, trained memory and body in order to study the numerical movements in the performance, which could last from one to seven days ${ }^{10}$. Thus, one can speak of certain originality, the specificity of the aforementioned theatrical space: being the space of creative development of reality, it can be attributed to the phenomena of culture and enter into the cultural space, which is formed through the creative activity of individuals aimed at transforming the natural world.

The peculiarity of cultural space is the granting of its temporal, spatial extent and axiological grounds. All this determines the axiological relation to the space-time aspects of being culture. At the same time, space and time are in unbroken unity, and objective spacetime relations exist as structured, multilevel integrity, as contradictory unity of different sides of being. At the same time, theatrical space as a kind of cultural space has also all its characteristics and simultaneously has a specificity that represents the ambiguity of axiological bases, which are characterized by temporal length and actual spatial boundaries.

Thus, the main feature of the values of the theatrical space is their contemporaneity, situational awareness: they are born and die with the performance and in tomorrow's presentation may not be repeated. Therefore, values in the theatre have nothing to do with the theatre itself (perceptions, photos, reviews, and so on). Even a taped performance ceases to be a theatre that exists in direct, live performance. The next performance may have different meanings, and make other accents. This allows the theatre-producing values to be positioned as preserving the atmosphere of uniqueness this evening, both for the viewer and for the people who create that atmosphere. Feeling of the uniqueness of the moment, the artistic event gives the theatrical effect ephemeral values and is a distinctive feature of the exclusively theatrical space ${ }^{11}$.

Thus, the "work" of the theatre concept is essentially based on the understanding of theatre as a universe, its explanation, interpretation.

${ }^{10}$ Batnasangiin S. (2009). Religiozno-istoricheskie nachala mongolskogo teatra [Religious and historical beginnings of the Mongolian theater]. Vestnik Tomskogo gosudarstvennogo universiteta, no. 320, pp. 73-75.

${ }^{11}$ Orlova E. V. (2009). Fenomen teatralnogo prostranstva: kulturfilosofskii analiz [The phenomenon of theatrical space: cultural philosophical analysis]. Izvestiia Saratovskogo universiteta. Seriia Filosofiia. Psikhologiia. Pedagogika, vol. 9, no. 3, p. 37. 
The concept of theatre, having integrity, is a vision of the theatre as such in its entirety, which allows us to speak about a certain ontological essence of its concept, the simulacrum, which is expressed in the desire to comprehend the existential existence of the theatre. By asserting the ontological fullness of the theatre concept, we also discover its substantive essence as a coherent system of meanings of theatre as such $^{12}$.

Spatial models, representations of theatrical space, have a multilayered structure and are a set of fundamental features (length, interruption / continuity, finiteness / infinity, dimension, and so on). It is these peculiarities that lead to the notion of a border that can be applied to theatrical space since its dialogical nature tends to be borderline. Theatrical art is on the border of all arts, all kinds of cultural space ${ }^{13}$. In particular, being a compound mental complex, the concept of theatre includes, in addition to its main content (the meaning of theatre as a universe), a number of components, for example, the national-cultural component of the concept of theatre (the meaning of the theatre functioning in a certain cultural environment), social (meaning the social function of the theatre), the individual-personal (subjective understanding of the theatre meaning of a particular personality) and other ${ }^{14}$.

It is significant in this respect that the spatial structure of any cultural phenomenon in the scientific literature is determined by qualitative and quantitative differences, so the first feature in which the concept of "theatre space" is separated from "theatrical space" is a quantitative, scale component. The theatre space is closed in one theatre, it is more local, static. Taking into account the division of theatrical space into the stage and the auditorium, the space of the theatre is the "stage". It absorbs everything that is inside - enters into the theatrical premises

12 Azeeva I. V. (2008). Kontcept teatra i traditciia filosofskogo znaniia ( $\mathrm{k}$ probleme formirovaniia teorii teatra $\mathrm{v} \mathrm{XX}$ veke) [The concept of the theater and the tradition of philosophical knowledge (on the problem of the formation of the theory of theater in the twentieth century)]. Izvestiia Rossiiskogo gosudarstvennogo pedagogicheskogo universiteta imeni A. I. Gertcena, no 11, p. 87.

${ }^{13}$ Orlova E. V. (2009). Fenomen teatralnogo prostranstva: kulturfilosofskii analiz [The phenomenon of theatrical space: cultural philosophical analysis]. Izvestiia Saratovskogo universiteta. Seriia Filosofiia. Psikhologiia. Pedagogika, vol. 9, no. 3, p. 37.

14 Azeeva I. V. (2008). Kontcept teatra i traditciia filosofskogo znaniia ( $\mathrm{k}$ probleme formirovaniia teorii teatra $\mathrm{v} X X$ veke) [The concept of the theater and the tradition of philosophical knowledge (on the problem of the formation of the theory of theater in the twentieth century)]. Izvestiia Rossiiskogo gosudarstvennogo pedagogicheskogo universiteta imeni A. I. Gertcena, no 11, p. 87. 
(from the creative part of the troupe to the prop, costume wprkshops and their workers, dressing rooms, etc.), and intangible substances - the relations of actors and director, the theatrical climate, the employment of actors, their relationships, the recharge of the troupe, all the theatrical rearrangements, scandals and so on. This includes not only the stage but also all the inhabited indoor theatre premises. It is a turn of the theatre life that people who do not belong to it do not see. The visible part of this space is the stage, the hall, the auditorium ${ }^{15}$.

It is generally accepted to represent the concept structure in the form of a circle consisting of a nucleus and a periphery. The concept of theatre also does not resist such a generalized-structural vision, in the centre of which is the basic concept, which is enshrined in vocabulary articles, and the periphery grows associative and other meanings, which are defined by the above components. Since the concept is intended to refer to the theatre as a category of meaning, it is natural to link the concept of theatre and the idea of theatre. The abstractness and discursiveness of the concept are developing thanks to the idea that, as a result of human perception of the theatre, it deploys the concept into a living theatrical organism $^{16}$.

At the same time, in the theatrical space, there is a dialogue with other types of cultural space, the culture itself, as well as all spheres that are not included in the structure of the cultural space. Communication here is widespread and has a wider spread. Theatrical space is open for mutual enrichment and interaction with other kinds of being. The space of the theatre is more closed in nature, it is static, closed in itself and carries only the characteristics of the theatre. Dialogue in the theatre space unfolds at the level of communication within it, but one space cannot exist without the other: a dialogue between theatre space and

15 Orlova E. V. (2009). Fenomen teatralnogo prostranstva: kulturfilosofskii analiz [The phenomenon of theatrical space: cultural philosophical analysis]. Izvestiia Saratovskogo universiteta. Seriia Filosofiia. Psikhologiia. Pedagogika, vol. 9, no. 3, p. 39.

16 Azeeva I. V. (2008). Kontcept teatra i traditciia filosofskogo znaniia (k probleme formirovaniia teorii teatra $\mathrm{v} X X$ veke) [The concept of the theater and the tradition of philosophical knowledge (on the problem of the formation of the theory of theater in the twentieth century)]. Izvestiia Rossiiskogo gosudarstvennogo pedagogicheskogo universiteta imeni A. I. Gertcena, no 11, pp. 87-88. 
theatrical space is as necessary as the dialogue between the stage and the auditorium $^{17}$.

The integration of scientific knowledge about theatre requires its conceptualization, which is done by constructing a theatre concept. The concept of theatre as a scientific definition is rarely used in the science of theatre. The concept of theatre in scientific knowledge is in some way an orderly bunch of theatre "meanings" as a universe. The conceptualization in the space of the science of theatre is more represented in the territory of theatre theory, which, as already noted, is the least developed scientific layer of theatrical science. This is largely explained by the weak demand for concept and conceptualism in the science of theatre. Appealing to the concept in theatre studies is often perceived as something depleting the theatre, as one that refines the artistic meanings ${ }^{18}$.

From a cultural point of view, theatrical space is a coherent ontological category that determines the place of theatre's existence in cultural space, so theatre space and theatrical space cannot exist without each other. Expanding the boundaries of the theatre space, compacting its semantic layer also leads to a change in the state of the theatre space, its qualitative characteristics and vice versa. However, neither one nor the other space exists without the creative participation of man as a subject of the theatrical process ${ }^{19}$. Such a distinction is, in our opinion, connected with the development of scientific knowledge of theatre, which is engaged in the complex of theatrical sciences, which are integrated into a voluminous independent scientific discipline (institution) of "theatre studies", which studies the theory and history of theatre. Theatrical Studies, which is one of the "young" art disciplines, its final formation as an independent scientific institution occurred in the

17 Orlova E. V. (2009). Fenomen teatralnogo prostranstva: kulturfilosofskii analiz [The phenomenon of theatrical space: cultural philosophical analysis]. Izvestiia Saratovskogo universiteta. Seriia Filosofiia. Psikhologiia. Pedagogika, vol. 9, no. 3, p. 39.

18 Azeeva I. V. (2008). Kontcept teatra i traditciia filosofskogo znaniia ( $\mathrm{k}$ probleme formirovaniia teorii teatra $\mathrm{v} X X$ veke) [The concept of the theater and the tradition of philosophical knowledge (on the problem of the formation of the theory of theater in the twentieth century)]. Izvestiia Rossiiskogo gosudarstvennogo pedagogicheskogo universiteta imeni A. I. Gertcena, no 11, p. 87.

${ }^{19}$ Orlova E. V. (2009). Fenomen teatralnogo prostranstva: kulturfilosofskii analiz [The phenomenon of theatrical space: cultural philosophical analysis]. Izvestiia Saratovskogo universiteta. Seriia Filosofiia. Psikhologiia. Pedagogika, vol. 9, no. 3, p. 40. 
twentieth century. This statement does not deny the sufficiently deep tradition of the science of theatre ${ }^{20}$.

\section{The Philosophical Discourse in Theater Science}

Characteristic of theatrical studies of the XX century there was a desire for philosophical conceptualization. In our view, the philosophy of art examines the links between philosophy and art through their focus on cognition, reflection, community, and at the same time individuality. In the work "The Source of Artistic Creation", M. Heidegger referred to art as the source of his own ability to think, as a form of truth. Genesis is hidden, but there are topos through which Genesis presents itself. Art (not philosophy) draws us to Genesis: the work of art is the creation. The world has never been a subject that we can see. The world is so meaningless that it has power over us. In the classical scheme of the relationship between philosophy and art, the latter has no category of thinking, thought is introduced into art, it is, because of its own specificity, the mediator between reality and philosophy, offering a special form of existence of truth. Heidegger pointed to art as a condition and round form of the deployment of thought about being. Truth in philosophy requires the basics, without the acquisition of which it is not true. But the art was originally located in the space of truth, otherwise, it cannot exist. The creative process is the deployment of truth in art. The philosophy of the theatre reveals itself in thinking about the nature of theatre regarding Existence. It is a collection of experiences, the pathos that acts directly on the human soul. From here on the theatrical stage, there is an opportunity to change psychological attitudes towards such moral and ethical categories as revenge, envy, jealousy and more. From this perspective, Shakespeare's works, in particular, are read in a new way. Shakespeare has ventured to transform the canon of a revenge tragedy through religious and ethical considerations rather than through theatrical theory and aesthetics. Why did Hamlet ultimately abandon his revenge? Where were the origins of his inaction? This "illness of character or will" was nothing but faith in God. It was a reluctance to

20 Azeeva I. V. (2008). Kontcept teatra i traditciia filosofskogo znaniia (k probleme formirovaniia teorii teatra $\mathrm{v} X X$ veke) [The concept of the theater and the tradition of philosophical knowledge (on the problem of the formation of the theory of theater in the twentieth century)]. Izvestiia Rossiiskogo gosudarstvennogo pedagogicheskogo universiteta imeni A. I. Gertcena, no 11, p. 86. 
break the commandments. There was a doubt that there was something in earthly life for which a person could lose his own soul.

Shakespeare reveals to us Hamlet as a man who is both in boundary dynamics and in statics. A number of external circumstances instantly put Hamlet in a situation of mistrust. At the same time, he has a rare ability to distinguish between good and evil. Shakespeare's character at first refuses to mix God with the devil, seeking support from both, emphasizing the need to distinguish between the higher powers that drive the actions of the earthly man. Honesty is the second core of Hamlet's character after faith. It can even be argued that it is pathologically honest. Hamlet is absolutely incapable of being reincarnated and hypocritical, so he chooses the truth of the madman. Shakespeare contrasts the image of Machiavellian (which became popular during the Elizabethan drama) the image of Claudius, characterized by the pangs of conscience and fear of punishment. Hamlet enters the play by choosing "to be" instead of Machiavellian's "give up".

Shakespeare has also a multifaceted structure of revenge. The action of Shakespeare's tragedy builds on a series of internal parallel lines, each of which incorporates a potential plot of revenge for the murdered father: the Hamlet Line, the Laertes Line, the Fortinbras Line, and, finally, the Ophelia Line. Through these lines and their juxtaposition, the playwright realizes his plan.

Moreover, the play contains a number of other plot options for revenge: the mention of the murder of Pyrom Priam (in the speech of the First Actor), the murder of Gonzaga, several references to the first murderer on earth - the murderer of his brother - Cain, and others. All this is nothing but revenge plot options.

"Hamlet" is a tragedy that examines the paradigm of revenge itself and in this sense is similar in genre to the problematic play.

The Ophelia line is too important. Beloved Hamlet's story and her strange and wonderful death is an alternative story of non-revenge in the tragedy. True tears instead of blood, a prayer for the salvation of all the souls of Christ is forgiveness, and therefore, approaching to grace. And finally, after her burial, Hamlet himself will make a speech about giving up intentional evil.

In each of the prince's mentioned precedents of revenge, there are own ascending conditions, own climax and own end. The situation, the paradigm of revenge is constantly changing, painfully analyzed by Hamlet, consistent with his idea of the proper state of the world and man. 
The tragedy of Hamlet's situation throughout his work is due to the dualism of his perception of the world: the confusion and mistrust of the believing person. In these circumstances, the search for a hero of integrity is tragic.

In Shakespeare's tragedy, one can find inexhaustible layers of meanings. They are already embedded in the plot-archetype of a father and a son addressed by a playwright. In it, the father is the creator, the beginning, the example, the ideal, the sacrifice. He has a son - an image, a disciple, a potential avenger, and also a victim. But also the carrier of a new worldview, which creatively interprets his father's commandments, gives the world new directions.

Shakespeare transformed a purely theatrical space, more precisely, purged it from intentional evil. The key themes of the "Macbeth" tragedy are mainly identified in the first two scenes. This is a regular rule of Shakespeare to indicate clearly the main semantic vector in the exposition of the work clearly. Therefore, the reader's job becomes much more complicated than the viewer's. If actors, artists, and directors are to help orient the viewer properly, the reader should pay special attention to the first scenes of Shakespeare's plays.

The first scenes of "Macbeth" emphasize three themes that will later develop into the main action. The first is the idea that there is no boundary between good and evil.

Secondly, it is a topic of uncertainty about fate and thirdly, it is a topic of valour as an imperative. Thus, Macbeth appears in the first scenes as a model of charity, but the viewer knows that in his soul the decision has already been made to change, in the language of Aristotle, the "direction of will" and to direct his best qualities to the achievement of other goals.

Shakespeare's Macbeth, whose crime is not a matter of error, but the result of his own choice, does not quite meet the requirements of the tragic hero. How did Shakespeare imagine the process of transforming man into his own instrument?

Almost as modern researchers call this blurry of individuality. Lady Macbeth's philosophy of action captivates the viewer. Fear is not a crime, but a thwarting of his attempt to commit it as well as a fascination with N. Machiavelli's philosophy of action, despite its immorality. Loyalty to oneself makes a person weak. It is an opinion that stems from Machiavelli's doctrine of the need to change behaviour depending on the circumstances, not so much as "being" but as "giving up" to one or the other depending on the situation. From the point of view of 
Machiavelli's follower Lady Macbeth, stability, loyalty to nature is not good, but evil for a hero who works for a great cause. She chooses the first option from two imperatives "consistency in purpose" and "loyalty to oneself".

Machiavelli pays much attention in the pages of his own treatise to reflect on the different tactics of those who go to power and who have already received this power. If one goal (the achievement of power) justifies a certain course of action, then another goal (the retention of power) provides a completely different tactic, doing harm to what has previously benefited.

"Things bad begun make strong themselves by ill" - "evil spreads evil" or "evil generates evil". This is how one can translate Shakespear's words, which have a deep philosophical basis for the arrangement of human nature and the laws of the human psyche. And all this takes place in a theatrical space in which Shakespeare created new meanings, experimented, modelled human nature and life situations.

Shakespeare theater was a medieval theatre. Shakespeare interpreted Machiavelli's teaching not as the reverse of the ideals of the Renaissance, but as their cruel replacement. The subject of change and unclean substitution in the medieval mind was the devil. This explains the logic behind identifying Machiavelli with him in English theatre and public consciousness. In fact, the literary-theatrical Anti-Machiavelli was created in England. Shakespeare's dramatic creativity is central to this discourse.

Shakespeare's inability to rely on individual prowess, the superiority of power over word and law, the notion of religion and belief as a means by which humankind could be kept in check was unacceptable.

Machiavelli, unlike Shakespeare, does not take into account the presence of God in human nature. Human cohabitation for Machiavelli is born of individual strength, arrogance, and the like. Instead, for Shakespeare, man is a divine creation of "all in all". Therefore, Hamlet forgives people's minor shortcomings.

Machiavelli has absolutely no perception of natural law and the idea of God's accomplishment. Shakespeare, by contrast, shares the traditional Christian view of the inability to know the ways of the Most High.

Machiavelli believed that it was more useful to appear kind, reliable, courageous and not to be them. Shakespeare, on the other hand, did not perceive veil and hypocrisy. 
Politics that overpowered conscience, wisdom devoid of sincerity, valor that destroyed ambition - all these things were condemned by Shakespeare, because they destroy the perfect picture of the world.

In 1608, the theatrical character of the Machiavellian cast became established in the English performing arts. Moreover, one can speak of the isolation of a particular psychological type of "political person".

The essence of Shakespeare's objections was clear to the viewer of varying degrees of education. At the heart of this answer are the notion of individual morality, moral law and the inevitability of punishment. These ideas relate to the tradition of medieval folk piety, which focuses on popular Christian commandments.

Having also covered the political component in the study of the concept of theatre and theatrical space, we have addressed the following questions: the particular features of Shakespeare's understanding of Machiavelli's teachings, the forms of the presence of Machiavelli's image, and the theme of Machiavellianism in his work and in the entirety of the Elizabethan culture; the reasons for the predominantly polemical perception of Shakespeare's Machiavelli doctrine, from which positions there was controversy, what is the essence of Shakespeare Machiavelli's objections; the conflict of ideas of Shakespeare and Machiavelli about the nature of the earth's helmsman and the legitimacy of the problem of "perfect helmsman" in the work of Shakespeare.

Shakespeare, unlike Machiavelli, stood for the Great Divine Order. Shakespeare's theatre was still closely associated with medieval religious theatre. However, for Shakespeare, there was already a secularization of consciousness. It was important that it was the motive of prayer in some of Shakespeare's plays, which points to the sacred role of theatrical space and the additional lever in the exchange of processes of consciousness. The monologue "To be or not to be" is a continuation of Hamlet's dialogue with his own soul. To endure the suffering of the earthly life or to rebel against it, that is, to die, to fall asleep? The philosophical component of the theatrical concept constantly appears in Shakespeare's plays.

The reflection of R. Barth's theatre is more intellectual in contrast to, say, the Russian theatrical tradition. Russian theatre looks like a holistic phenomenon, a kind of monolith. Theatre, in the interpretation of $\mathrm{R}$. Barth is absent in its isolation, the rejection of conventions. The ideal for Barth is an epic, rich in philosophical ideas, the B. Brecht theatre. Theatre does not reject rationality but represents rationality as a means of solving urgently important problems. In the modern world, the B. Brecht 
theatre embodies the functions of philosophy rather than philosophy itself. Brecht returns to the theatre the forgotten role of the forum.

According to one of the theatre reformers of the twentieth century, A. Artois, the theatre became too dependent on the word, on the text, on the play, which is interpreted exclusively verbally in the contemporary theatrical space. The theatre became literary. Instead, Arto believed, the theatre should lose its focus on the written word.

In our view, the philosophy of theatre is represented by the conception of the Russian philosopher and theatre theorist M. M. Yevreinov, who largely foresaw the idea of "theatricalization of life." The person has an instinct, which, despite his inexhaustible vitality, neither history, nor psychology, nor aesthetics has not been spoken about yet. It means the instinct of transformation, the instinct of opposing images that are arbitrarily created by man. Theatricality can be applied to different situations of life and revealed in all spheres of human life. Theatre is a detailed metaphor of the nature of human behaviour. Theatre in the narrow sense of the word (art) is regarded as a concentrated form of universal and general laws of being. Theatricality is another reality of life, irrespective of the laws of everyday life, with its real logic, with its morality and feelings. The origins of theatricality, according to Yevreinov, are hidden in the depths of all human culture and have their original, biological roots. Theatricality appears before the emergence of civilization and homo sapiens. In the article "Theater at Animals" the author finds examples of theatrical behaviour even in plants (imitation, mimicry), where the ability to "give up" is not a futile step, but a necessity in the process of survival.

"The Philosophy of Theater" is a unique creation of S. D. Krzhyzhanovskyi. The work traces the movement and development of the theatre. According to the author, a true philosophy of theatre is possible only if the theatre and everything else coincides, that is when there is nothing in the world that would not be a theatre in one or another of its modifications. Krzhyzhanovskyi reveals the similarity of Kantian philosophy and theatrical scenario (the scenario of the theatre life or its fate), which helps him to ask the question about the essence of theatre. After all, if you take the essence of the script and the "Critics of Pure Reason", they are surprisingly similar. I. Kant as a majestic figure of world culture is compared not only with the theatre in general but also with its most prominent representative Shakespeare. Theatre is a game of phenomena, a game of ghosts. The game of what does not exist in the real world, but at the same time, that brings us to the everyday level. All 
that plays out on stage is the fruit of our imagination, the play of ideas and meanings, but all this can not exist only in our head. The play of the actor gives the opportunity to invent and to think, it allows new meanings to be born in which the ontological content is ordered. The stage and the actor play are the models of real life.

Krzhyzhanovskyi's methodology has its own game - a game with the category of being. It comes from being, and as a result, there are three important mods for the analysis of the theatre concept: the history of the theatre can be represented as the birth of "theatre of being" (mystery), change it as "theatre of life-being" (tragedy), then "theatre of life" (drama). The stage is captivated by the strongest. Changing the theatrical language of contemporary theatre, Lehman considered the result not only of the aesthetic evolution of the theatre itself but also the result of the profound transformations that modern society and the human personality undergo. First, we are talking about the "Guttenberg era" crisis, which has been spoken about a lot lately. In the XXI century, the very nature of perception changed. Multifaceted one replaces linear and consistent understanding. The literary text, the book were dealt a serious blow. Slow reading, as well as thorough, heavyweight theatre, risks losing its status. The theatre is no longer a medium of communication. In the conditions of rapid technocratic development of civilization, "speed" and "superficiality" become factors that hinder the release of active energy of human imagination, which leads to the passive consumption of information and artistic images. And theatre and literature, which are predominantly iconic rather than illustrative, require focused and indepth perception. In addition, the sphere of culture is increasingly subject to the law of profitability. However, with the obvious conservatism caused by its very nature, theatre, nevertheless, is in a state of constant search and development. This is a prerequisite in order to maintain a place in society and to compete with technically sophisticated means of communication. At the same time, Lehmann acknowledges that not all theatrical forms of recent decades are in line with the post-dramatic paradigm. However, in the second half of the 1990s, an opposite tendency emerged, which, according to some experts, proved the most productive - a new realism. This is a depreciation of symbolic language in favour of the theatre, which, through self-reflection and self-reference, only realizes its own theatricality or largely refuses the language for the sake of performative theatre of physicality, new realism contrasts the rehabilitation of dramatic text, hero and action. "Post-dramatic theatre" 
and "new realism" are the two most important poles of modern European theatre now.

\section{CONCLUSIONS}

The cultural significance of the theatrical space's values has a dualorientation. Valuable grounds arise as a result of the theatrical process. They constitute both aesthetic and ethical, literary, political, and even material (scenery, props, costumes, and so on) values. Such versatility of localization leads to the opposition of "space of theatre" - "theatrical space". The theatre space has a more local character, less mobile, attached to a certain materialized theatrical space as the location of the theatre in the city space, life. Instead, theatrical space has broader boundaries, a wider spectrum of distribution, and theatrical space is a definition that includes all the features of the theatre, it is used when considering the variety of forms of existence of the theatre and it is related to the characteristic its concept.

Identifying the concept of theatre in the tradition of philosophical and actual theatrical knowledge, the analysis of this phenomenon allows us to confidently assert not only the presence of integrative use of philosophical discourse in theatre, but also the obvious perspective of concentration on the concept of theatre for the development of the science of theatre in general, and in general, for his theory and practice.

The above confirms the relevance and urgency of the study, whose purpose is to identify the presence of the concept of the theater on the basis of the analysis of theoretical and practical material of the theatrical art. It should be noted that in the process of deep appeal to the theatre as a category of meaning, it is important to seek to understand theatre as a concept in the scientific and artistic knowledge of previous eras, up to the time of pre-scientific knowledge, which actualizes a number of ideas about theatre in mythology, religion, and language.

In order to grasp theatrical space, one must become a "man of the theatre", which will become one of the defining phenomena of the professional and creative vocation of a young man, who decides to devote his life to the art of theatre, theatrical professional activity. Therefore, the formation of the foundations of the phenomenon of "theatre man" is one of the primary tasks of the theatre school, which deals with the education of modern creative personality. 


\section{SUMMARY}

The purpose of the article is to identify the concept of theatre and to determine its role in theatrical studies on the basis of the theoretical and practical material's analysis of the theatre arts. The methodology and theoretical basis of the study are determined by the purpose of the article, the specifics of the subject and object. The main theoretical basis of the study were works on the theory, philosophy, history and methodology of the culture of such cultural scientists and philosophers as M. M. Bakhtin, V.S. Bibler, M. Ya. Danilevskyi, I. O. Ilin, M. S. Kahan and others The sociocultural approach made it possible to consider the concept of theatre as a multifaceted and multifaceted process. The systematic approach provided the opportunity to use in the study of a whole range of methods: comparative, biographical, cultural-historical, axiological, hermeneutic, chronological, semiotic, differentiation, typing, grouping and modelling method. The scientific novelty of the obtained results is comprehensive coverage of the concept of theatre. Scientific conclusions have been made regarding the nature, features and objectivity of the existence of this phenomenon in culture and the justification for the necessity and feasibility of its further study. Conclusions. Revealing the concept of theatre in the tradition of philosophical and actual theatrical knowledge, analysis of this phenomenon allow us to confidently assert not only the presence of integrative use of philosophical discourse in theatre but also the obvious perspective of concentrating on the concept of theatre in the development of science of theatre and especially for his theory and practice.

\section{REFERENCES}

1. Adrianova T. O. (2014). Teatr kak sotciokulturnyi fenomen [Theater as a sociocultural phenomenon]. Vestnik Orenburgskogo gosudarstvennogo universiteta, no. 168, pp. 82-85.

2. Azeeva I. V. (2008). Kontcept teatra i traditciia filosofskogo znaniia (k probleme formirovaniia teorii teatra $v \mathrm{XX}$ veke) [The concept of the theater and the tradition of philosophical knowledge (on the problem of the formation of the theory of theater in the twentieth century)]. Izvestiia Rossiiskogo gosudarstvennogo pedagogicheskogo universiteta imeni A. I. Gertcena, no 11, pp. 85-92.

3. Batnasangiin S. (2009). Religiozno-istoricheskie nachala mongolskogo teatra [Religious and historical beginnings of the Mongolian theater]. Vestnik Tomskogo gosudarstvennogo universiteta, no. 320 , pp. $72-75$. 
4. Diachenko R. (2017). Hotels and restaurants of Lviv in the context of hospitality : past and present. National Academy of Managerial Staff of Culture and Arts Herald, no. 2, pp. 41-45.

5. Kalinina S. A. (2011). Leksiko-frazeologicheskaia reprezentatciia kontcepta "Teatr" v russkoi i angliiskoi lingvokulturakh [Lexical and phraseological representation of the concept of "Theater" in Russian and English linguistic cultures]. Teoriia $i$ praktika obshchestvennogo razvitiia, no 8, pp. 374-377.

6. Nikitina O. N. (2016). Istoricheskaia dinamika iskusstva: muzyka $i$ teatr [The historical dynamics of art: music and theater]. Izhevsk: Udmurtskii universitet. (in Russian)

7. Orlova E. V. (2009). Fenomen teatralnogo prostranstva: kulturfilosofskii analiz [The phenomenon of theatrical space: cultural philosophical analysis]. Izvestiia Saratovskogo universiteta. Seriia Filosofiia. Psikhologiia. Pedagogika, vol. 9, no. 3, pp. 36-41.

8. Ovcharuk O. (2018). Transformation of human immediates in Post modern cultural practices. National Academy of Managerial Staff of Culture and Arts Herald, no. 4, pp. 12-16.

9. Vozgrivtceva K. I. (2005). Teatralnoe prostranstvo: kulturologicheskii aspekt. Izvestiia Uralskogo gosudarstvennogo universiteta, no. 35, pp. 57-63.

10. Yan I. (2017). Ukrainian music and drama theater in the context of the nation creation process of the last third of the XIX - beginning of XX century. National Academy of Managerial Staff of Culture and Arts Herald, no. 2, pp. 119-121.

\section{Information about the author:} Ishchenko Yevhenii, orcid.org/0000-0002-5701-7829 $\mathrm{PhD}$ in Philology Kyiv International University 49, Lvivska Str., Kyiv, 03179, Ukraine 
DOI https://doi.org/10.36059/978-966-397-197-1/129-152

\section{THE PECULIARITIES OF BANDURA SOUND PRODUCTION: THEORETICAL AND PRACTICAL ASPECTS}

\section{Broiako Nadiia}

\section{INTRODUCTION}

The contemporary world cultural processes are defined by deep informatization of culture and artistic space, the interaction of different ethnic cultures and types of civilization (on grounds of mental, religious, and ideological identity) and at the same time, the aspiration of the peoples, ethnic groups and small-numbered ethnic groups for avoiding the "self-dissolution". The traditional basis of folklife culture brings forward the ethic culture.

In Ukraine, the revival of traditional music, kobza performance, and academic bandura art meet the contemporary art trends and criteria of the global values. Therefore, the training of a new generation of bandura players is necessary and well-timed. Bandura playing skills as the line of research for music performing arts are topical in the works of many scientists: N. Davydov, "Folk Instrument Performance History" ${ }^{1}$, N. Davydov "Kyiv Academic School of Folk Instrumental Art"2, V. Dudchak "Bandura Art of Ukrainian Emigre Community of the 20th Early 21st centuries"3, I. Zinkiv "The Bandura as a historical phenomenon"4, V. Kushpet "Traveling Musicians in Ukraine of the

${ }^{1}$ Davydov M.A. (2010) Istoriia vykonavstva na narodnykh instrumentakh [Folk Instrument Performance History]. Lutsk: Volyn Regional Printing House.

${ }^{2}$ Davydov M. (1998) Kyivska akademichna shkola narodno-instrumentalnoho mystetstva [Kyiv Academic School of Folk Instrumental Art]. Kyiv: Ukrainian National Music Academy Tchaikovsky.

3 Dudchak V. (2013) Bandurne mystetstvo ukrainskoho zarubizhzhia XX pochatku XXI stolittia: Monohrafiia [Bandura Art of Ukrainian Abroad of the 20th early 21st Century: Monograph]. Ivano-Frankivsk: Foliant.

${ }^{4}$ Zinkiv I. (2013) Bandura yak istorychnyi fenomen: Monohrafiia [The Bandura as a historical phenomenon: Monograph]. Kyiv: The Rylsky Institute of Art Studies, Folklore and Ethnology. 
$19^{\text {th }}$ - beginning 20th century", V. Kushpet "School of reconstruction of the performing tradition (kobza, lira, torban, bandura, singing)" ${ }^{16}$, V. Mishalov "Kharkiv bandura", A. Omelchenko "School of bandura playing" ${ }^{8}$, Y. Puchalski " The teaching technique of bandura playing"', M.Khai "Mykola Budnik and kobza art"10. These works, of course, are unique scientific tools in musical performing activities of banduraplayers as a system of concepts, terminology, methodology and techniques. The authors' concepts allow for many themes and interpretations with a view to their rational use for bandura art along with a revolutionary basis - on the basis of the in-depth study of the specifics of bandura sound production and phonation.

It should be noted that the publications about bandura genre in studies of the twentieth century (by the time of Independence) because of the ideological canons of the Soviet State was reduced to the identification of certain facts of professional education of bandura players, but did not give the optimal characteristics of this art as a unique authentic and academic artistic and technological mental thinking as a Ukrainian national identity factor in musical performance.

When the Soviet-era ideological guidelines in Ukrainian musicology were stopped, interest in the authentic musical tradition was renewed, and scientific interest in the high spiritual mission of the national musical instrument began to grow. Researcher N. Chernetska notes: "Bandura performance is a significant factor in the patriotic upbringing of young people, which is especially important in the process of forming national

${ }^{5}$ Kushpet V. (2007) Startsivstvo. Mandrivni spivtsi-muzykanty v Ukraini XIX pochatok XX storichchia [Eldership. Travelling Musicians in Ukraine the 19th beginning 20th century]. Kyiv: Tempora.

${ }^{6}$ Kushpet V. (2016) Shkola rekonstruktsii vykonavskoi tradytsii (kobza, lira, torban, bandura, spiv) [School of reconstruction of the performing tradition (kobza, lira, torban, bandura, singing)]. Kyiv: Tempora.

${ }^{7}$ Mishalov V. (2013) Kharkivska bandura: kulturolohichno-mystetski aspekty genezy i rozvytku vykonavstva na ukrainskomu narodnomu instrumenti [Kharkiv bandura: Cultural and Artistic Aspects of Genesis and Development of Performance on the Ukrainian Folk Instrument]. Kharkiv: Publisher Savchuk O. O.

${ }^{8}$ Omelchenko A. (1973) Shkola hry na banduri [A handbook for the bandura]. Kyiv: Muzychna Ukraina.

${ }^{9}$ Pukhalskii Ia. G. (1978) Metodika obucheniya igre na bandure [The technique of teaching bandura playing]. Kyiv: Goskonservatoriia.

10 Khai M. (2015) Mykola Budnyk i kobzarstvo [Mykola Budnyk and kobzarstvo]. Lviv: Astroliabiia. 
landmarks for the modern young generation and will in some way affect the content and structure regarding the values of Ukrainian society in the future". 11

At the same time, the in-depth disclosure of the mental nature of playing the bandura, like any kind of musical performance, requires recourse to its layers, laid in the thick of performing folk tradition, which has clearly defined features inherent in this original national instrument. Exploring the open environment of the musical space of the $20^{\text {th }}-21 \mathrm{st}$ centuries, V. Dorofeyeva notes: "The contemporary style space of Ukrainian academic music demonstrates a correlation between tradition and innovation. One of the leading features of the creativity of most composers is the free use of the achievements of the previous centuries,... and the main feature of the stylistic space of Ukraine is the appeal to new folkloristics, which is manifested in a type of modal tone complex". ${ }^{12}$ Academic bandura performance of today, being at the forefront of modern music-style trends, is deeply rooted in the traditional timbre and sound sphere. It is important to understand and analyze the theoretical performance aspects of bandura sound production and to find ways of practical implementation of sound images.

\section{Bandura Sound Production as a Means of Artistic Expression}

Understanding the problems involved in sound production is extremely relevant in the creative process of a musician of any speciality. Without mastery of the specific sound production on the instrument, it is impossible to achieve a clear, artistically perfect performance and complete reproduction of the artistic content of a musical work.

Researcher of related performing genre (Domra) O. Oliynyk, has carried out a number of scientific studies in the field of artistic and figurative intonation regarding instrumental sound, emphasizes: "In our time, instead of a permanent hierarchy of "artistic and self-sufficient applied creativity", variable orientations are put forward, layers and

${ }^{11}$ Chernetska N. (2018) Vykonavska tvorchist bandurystiv Volyni yak dzherelo formuvannia natsionalnoi samosvidomosti [Performing creativity of bandura players in Volyn as a source of formation of national consciousness]. Bulletin of the Kyiv National University of Culture and Arts. Series: Musical Art, vol. 1, p. 90.

${ }^{12}$ Dorofeeva V. (2016). Formuvannia suchasnoho muzychnoho stylovoho prostoru na prykladi tvorchosti ukrainskykh kompozytoriv [Formation of modern musical style space on the example of creativity of Ukrainian composers]. Muzychne mystetstvo i kultura [Music art and culture], vol. 23, p. 267. 
levels of artistic expression, which has led to the academicization of a number of genres and links in the popular music-creative practice, including playing folk instruments that have historically been formed in folk art in these countries, and only in the last decades, have they acquired a new artistic and aesthetic meaning and gradually entered the sphere of academic creativity and performance". 13

However, as evidenced by performance and pedagogical practices, there is still a widespread tendency among academic bandurists to underestimate the significance of sound production, which leads to impoverishment of the artistic and visual palette of the instrument and gives rise to misconceptions about its imperfect nature preventing it from engaging alongside such local classical solo instruments like the harp and guitar.

At the same time, the practical activities of leading concert performers, the experience of well-known Ukrainian bandura educators allow us to carry out a complex analysis of the instrumental specificity that underlies the whole process of forming the bandurists artistic technique.

Summarizing his rich performing and pedagogical experience, G. Neuhaus briefly formulated the principles of working on sound: "The first is the "artistic image"(i.e. meaning, meaning, expression, "what is it about"); secondly - sound in time - objectification, materialization of the "image" and, finally, thirdly - technique in general as a set of means necessary to solve an artistic task, playing the piano "as such", i.e .owning his musculoskeletal apparatus and mechanism instrument"14" This principle should be fundamental in the process of forming a brilliant instrumentalist.

Bandura sound production, in terms of auditory perception, like sound production on any other musical instrument, is characterized by the following basic properties: height, strength, duration and timbre. The understanding of sound production in the aesthetics of the performing arts is somewhat different than in acoustics. Here we are primarily referring to the quality of sound, its ability to serve as as a carrier of an

13 Oliinyk O. (2018) Domrove tremolo $\mathrm{v}$ aspekti rytorychnoho zmistu vykonavskykh pryiomiv hry [Domra Tremolo in Terms of the Performance Techniques Rhetoric Context]. Bulletin of the Kyiv National University of Culture and Arts. Series: Musical Art, vol. 1, p. 58.

14 Neuhaus G. (1988) Ob iskusstve fortepiannoi igry [On the Art of Piano Playing]. Moscow: Muzyka, p.69. 
artistic idea, and not so much as one, separate, or many groups of sounds, musical phrases, melodies. F. Chopin, paid considerable attention in his concert and pedagogical work to the quality of sound produced, and said that "as one word does not make a language, so one abstract sound does not make music". ${ }^{15}$

Sound production, as a primary means of artistic expression, is also an important element of individual performance style. It may be beautiful or not beautiful, soft or firm, gentle or dramatic. Depending on this, a bandura in the hands of a performer will cry or laugh, sing or growl, click, dance or console. In terms of the beauty regarding the sound produced, the most prominent bandurists of the 20th -21 st centuries received the highest praise and positive epithets - Hnat Khotkevych, Vasily Yemets, Hryhory Kytasty, Serhiy Bashtan, Alla Sheptytska, Petro Chukhrai, Volodymyr Yesypok, Halyna Menkush, Victor Mishalow, Roman Hrynkiv, Heorhiy Matviyiv, Serhiy Zakharets.

A bandura string is whimsical: plucking or hitting it in different places vertically - from the bridge to the pegs - we obtain a variety of sound colours. The reason for this is the inhomogeneous elasticity of the string. Near the bridge and upper peg box the string is "harder", the possibility of its deformation is much smaller, and therefore the oscillatory process that is set up in such a place, creates an original sound colour - "under the mute". In the middle of the string, it is much softer and subject to varying degrees of deformation, so it is at this point of excitement that we achieve the most dynamically bright and full sound regarding timbre.

While working on sound production is an important part of a professional musician's training, it should be remembered that a sound is an important tool, but not the primary purpose of performing. "What moves us as beautiful sound," says G. Neuhaus, "is actually something much more - it is the expressiveness of the performance, that is, the organization of the sound in the course of the performance of the work". ${ }^{16}$

In order the work on the sound production to be effective, the performer must understand the need to possess a beautiful, high-quality sound, clearly presenting in his mind the form of the sound, its colour,

${ }^{15}$ Milshtein Ia. I. (1967) Sovety Shopena pianistam [Chopin's advice to pianists]. Moscow: Muzyka, p. 19.

${ }^{16}$ Neuhaus G. (1988) Ob iskusstve fortepiannoi igry [On the Art of Piano Playing]. Moscow: Muzyka, p. 81. 
emotional load and sound-motion necessary in order to realize an artistic idea. Extremely interesting in this aspect is K. Martinsen's concept of "sound-production will", which can be formulated briefly as a continuous chain of artistic performances: I imagine - I perform - I hear. The outstanding researcher attaches particular importance to the indivisibility of the act of execution and the synthesis of its basic constituent elements: "Never can a spiritual impulse in itself be an element of creativity, just as musical hearing or a muscular system, be considered separately". ${ }^{17}$

The musical movement is born out of the interaction of the musicalperformance movement and the string. We consider sound-making movements to be methods of sound production on the bandura, among which the main ones are pluck and rest stroke. Next to the concept of "beautiful" sound production, there is a concept of "ugly" sound, which may be due to inconsistency and imperfection of the mechanical and physiological order. The main reason for poor sound quality may be an imperfect, or "dead" instrument, an inaccurate tuning system, the unregulated levers and switches of the retuning mechanism. But if mechanical defects can be eliminated relatively easily, problems of the physiological and artistic plan can be prevented by carefully polishing factors such as applicative orientation, understanding the arrangement of intervals chords on the strings, proximity of the fingers to the strings, the use of orientation-touching, auditory coordination in the representation on the basses and the main strings, and the rational use of hand weight. If a musical instrument materializes perfect sound images and, in the process enriching, updating the real world of sounds, forming new, more interesting musical-sound ideas, then the performer by his nature, his high artistic taste and intellect should become the life-giving creator and soul, filling the mechanical substance with a variety of emotions and feelings. Only in such a combination will the surrounding world and the essence of a human being in it be opened to us in the multidimensional sound space creating the artistic image of a musical work. The bandura performer's will, the "direct creators" of the bandura playing are the fingers, the parts that become mediators, the guides of the path from the performer's heart through the maze of strings and soundboard to the heart of the listener.

17 Martinsen K. (1977) Metodika individualnogo prepodavaniia igry na fortepiano [Methods of individual piano teaching]. Moscow: Muzyka, pp. 26-27. 
Overcoming the resistance of the strings determines the shape of the bandurist's movements, in which the methods of sound extraction, based on the span and weight of the hands, predominate to achieve volume. Bandurists need to train not only the muscles of the fingers, but also the wrists, forearms and shoulders, to specifically improve the control of the activities of the extensor muscles.

In general, the specificity of the bandura requires close contact of the artist's fingers with the strings. Therefore, before moving on to the development of various skills of contacting the hands with the strings, it is necessary to understand the bandura specifics of applicative orientation. Applicative orientation is the complex representation of the performer of harmoniously-harmonic relations regarding the extracted sounds, the formal structure of the construction of the finger movements on the strings and their coordination in the process of playing. There is a need for preliminary analysis of stringed row(s) because the same intervals and chords on different degrees of scale may have a completely different arrangement. A second in major only from the 3rd and 7th degree on the main row, and from the 1st, 2nd, 4th, 4th and 4th levels it is possible to play this interval only with the help of the strings of the upper row, which necessitates a change in the method of sound extraction or change of position of the playing apparatus.

Intonation problems that arise as a result of the design and construction features of the bandura give rise to a number of technical difficulties. Without comprehending the string row in its real "sounding" is a complicated reading of the notes from manuscript, transposition, hearing, improvisation. Particular attention should be paid to the bass due to the inability to use the left thumb. The performer must compensate for this disadvantage by actively using the fourth and fifth fingers. The first step to developing the orientation here is to memorize the order of the strings, which is facilitated by their small range (one octave), the specificity of cutting the upper nut, when the upper row produces a diatonic scale of $\mathrm{C}$ major, and the lower the additional chromatic notes.

To create a muscular sensation of the required distances, the applicative-auditory orientation it is useful to do silent exercises in the repeated easy permutation of the fingers on the strings with a clear understanding of the particular intervals. Such exercises activate the imagination of the performer, allows him to focus on the basics for orientation - the distances and directions of individual movements, as well as the internal auditory perception of sound, dynamic and other 
relationships. Real playing activates the performer's attention on the assessment of what he hears and what he does not, silence - on the lead of the playing, enhances the role of consciousness, subconscious and intuition. The proximity factor of the fingers on relation to the strings is related to their vertical position on the bandura, which ultimately leads to inconvenient visibility of the string rows and the lack of visibility of the working bass range. The tactile and orientational ability of the fingers must compensate for this lack of visibility. The continuity of such contact ensures reliability for their implementation and is one of the essential sides, which is a specific feature of the bandura technique. From this, it is easy to understand the importance of developing the activity of the bandurist in controlling the movement of the muscles, including those of the fingers and the wrist. A significant role for both single and double notes, octaves, chords is played by the transverse and longitudinal movements of the fingers and hands, the placement of the thumb, as well as the narrowing and stretching of the wrist.

One of the conditions for playing reliability is the feeling of continuous contact of the bandurist's fingers with the strings. Extremely valuable and innovative is the studies by Y. Pukhalsky in bandura methodology and the concept of preparatory playing movement: «the purpose of preparatory movements of fingers, hands, forearms of the player - to ensure the error-free playing of necessary strings; and on the other hand, these preparatory movements should provide the necessary repetition". 18

Therefore, preparatory playing movements can be considered as an element of staging, which effectively allows the process of sound production. Since musical performance is not possible without a clear organization of playing movements, the important role played by preparatory movements in the process of artistic sound production is obvious. The author distinguishes the following types of preparatory movements:

- the fingers are pre-installed directly on the strings;

- the fingers are pre-positioned above the desired strings at some distance from them;

- fingers are appropriately positioned (opened) when moving the hands over the strings. The performer is confronted with this kind of

${ }^{18}$ Pukhalskii Ia. G. (1978) Metodika obucheniya igre na bandure [The technique of teaching bandura playing]. Kyiv: Goskonservatoriia, p. 48. 
preparatory movements when performing individual sounds or harmonies, located at a considerable distance. ${ }^{\text {.9 }}$

It is necessary to develop the skill of feeling the finger as a starting touchpoint for subsequent movements. An unreasonable detachment of the hand from the string row breaks the tactile communication in the movement, leading to errors, particularly harmful during the period of learning the work. These inaccuracies of the initial movements subsequently lead to an "unclean" sound.

A very important point is the training of focus simultaneously in different planes. The task is to control the parallel movement of two hands. The variant method is effective: the focus is alternately on the bass, then on the treble strings. Focusing on one area of activity does not mean ignoring the other completely. Translated into the background, the left hand is involuntarily controlled, sometimes to a greater extent than the right.

A characteristic feature of diversified attention is the uneven intensity of nervous energy. Outstanding performance cannot be controlled at the same time with the same quality. If we focused our attention on one object, then the phenomena, objects, and actions that surround us are controlled by the "accompanying waves" of nerve energy in another plane.

In the course of playing there is another feature worthy of attention the periodic involuntary transition of the first plan of attention to the second and vice versa, and the second - to the first. In accordance with this pattern, it is advisable to vary the focus of the auditory-motor imagination alternately on the bass, and then on the treble strings. As an auxiliary, the variability of audio-motor sensations is used, for example, an unequal juxtaposition of bass and fringe depth of sound, strokes, weight sensations, etc. The importance of orientation skills and techniques in the acquisition of techniques of artistic performance is that they are the key to selecting appropriate, rational movements for clean and accurate performance.

Psychophysiological patterns of performing motor skills on stringplucked instruments, unfortunately, are not covered in the methodological literature and are an indispensable area for the study and creation of a voluminous picture of the application of scientific knowledge of

${ }^{19}$ Pukhalskii Ia. G. (1978) Metodika obucheniya igre na bandure [The technique of teaching bandura playing]. Kyiv: Goskonservatoriia,p. 49. 
psychophysiology in music and the performing arts. During the study of the particular work and mastering the whole technical complex, the performer focuses on other essential aspects of his skill.

When used rationally, the weight playing provides the following tactile-motor sensations and muscular reactions: the support of the finger pads on the string; the feeling of overcoming the resistance of the string; saving energy and magnitude of movements in muscular pulsation; readiness of the finger for the next pluck, stroke; continuity of serial communication of sound in passages. Weight play is the basic feeling on which the natural organization of the locomotor system as a whole is formed because it promotes the proper functioning of the parts of the arm and muscular system, the coordination of their work.

Care should be taken to ensure that the weight of the hand is distributed evenly across all fingers. It is more difficult to feel when applying the thumb. While performing the passage, the sensation of weight should not stop on any string. Work in this regard can be considered complete if you can "place" your hand in the passage. Weight play nurtures reliability, the confidence of execution, the timidity of the string row disappears, automaticity of movements is developed - a necessary condition for artistic performance. To bring the skill of the weight playing to perfection, each piece of the work, where the continuity, fluidity of the weight sensation, need to be played several times, seeking a total, continuous collection of the sound is necessary. As you master the technique, the need for a special setup for the weight playing is eliminated. There remains a positive sense of naturally organized and appropriate contact with the string.

But no matter how effective this or that method of refining sound is, its ultimate goal is automation, bringing movements into the realm of the subconscious. In the case of prolonged work in the weight playing one can also be observed negative phenomena: fatigue, loss of muscle ability, exclusion of figurative thinking. Similar effects are inevitable when this method becomes an end in itself, when muscle pulsation is not controlled when applied.

Bandura playing should use the appropriate measure of hand weight, which will be sufficient to overcome the resistance of the string. Finger weights are, of course, sufficient when performing notes of short durations. To achieve the long-lasting sound of thirds, sixths, octaves, chords, it is necessary to use other parts of the playing apparatus: the muscular system of the shoulder girdle, shoulder, elbow and wrist joints. 
They need to be integrated, in whole or in part, into the sound-making process in the case of artistic expediency.

In I.E. Koch's work "The Basics of Stage Movement" a classification of movements is made up, which includes five groups: general, working, semantic (related), illustrative, pantomime. ${ }^{20}$ The music-playing process includes, the first and secondary, as well as illustrative and pantomime movements, which manifest themselves spontaneously, and therefore cannot be a goal in the development of the bandura player's performing technique. We are primarily interested in working movements because they are at the heart of the formation of bandura sound.

A prerequisite for improving coordination in all its varieties is the auditory-motor representation. It gives impetus to expedient, controlled playing movements. In the initial period of study, the student perceives the musical text mostly visually or by ear. Kinematic expedient reflexivity is not yet developed. This leads to breakdowns. Coordination of movements is often hindered by the difference in the development of the left arm of the bandura player from the right.

The concept of "weighted playing" means economizing the energy in the muscles of the fingers and hand by using the weight above the upper arms. The use of this weighting method on the bandura is sometimes questionable: can the hand weight be used when the strings are almost vertical as opposed to gravity? The sensation of the weight of the hand on the vertical plane is achieved by the grasping, sliding, gripping movement of the tips of the finger (lateral part) into the palm. If on the horizontal plane, the weight of the armrests on the arch formed by the finger between the nail and the wrist phalanges, with an equal load on both these points, then the vertical position plays the role of this support by the gripping movement of the tip of the finger and nail phalanx.

As for weight as a factor in achieving a particular volume, it directly affects the amplitude of the oscillation of the string. The effectiveness of the method of weight play on the bandura is determined not only by the achievement of the volume of sound, but also by establishing the naturalness of consistent.

Coordination is the result of specially organized labour. Its formation is facilitated by the principles of consistent mastering of technical difficulties from the simple to the complex, as well as the method of

${ }^{20}$ Kokh I. E. (1970) Osnovy stcenicheskogo dvizheniia [The Basics of the Stage Movement]. Leningrad: Iskusstvo 
dividing up complex technical tasks into simpler components. The first step to developing coordination is training in purposeful management of one's muscular condition (active-passive). The artist must learn to subtly feel and use exactly the minimum energy required to solve a particular artistic task. Coordination requires long, painstaking work and many exercises.

Particular attention should be paid to improving the bifunctionality of left-hand movements. The inconvenience of fingering and the exceptionally tangible manner of orienting the fingers on the bass strings forces the bandura player to constantly distribute attention between the comprehensive (logical, scalic-harmonic, applicative fingering, type of stroke) comprehension of the structure and perfect mastery of the skills and techniques of finger movements. By combining different types of movements within a holistic complex, it is necessary to focus on preserving and improving those skills and muscular reactions that were previously learned as appropriate for the implementation of this task. Therefore, multidimensional attention is needed. A method for shifting attention from one movement to another is very effective. For example, from the bass to treble strings, from one stroke to another, etc. This allows us to define the broad concept of coordination in the musicperformance process as a unity of feelings, thoughts and movements.

Sound production mastery is the ability to hear and shape it from the moment of attack to its end. That is why the bandurists' special concern is the technique of "pure" production of sound devoid of nail noise. It is possible to achieve this level of performing technique by applying the pre-positioning of the fingertip on the string. The finger supported by the finger pad will prevent unpleasant "buzzing" arising from the friction between the metal and the nail. The nature and duration of the sound of the bandura depend mainly on the moment of the excitation of the string, after which the gradually decaying sound is not possible for the performer to change its dynamics (except for the tremolo mode). Therefore, not only the melodic line, but also the passages should be richer and more flexible (more exaggerated than in other instruments) in order to clearly convey the intonation of the music being played.

Sometimes the incongruence of the playing apparatus with auditory control leads to hypertrophied nuance, resulting in noise. As a result, performers should always remember that even in the most emotional, dynamic and loud episodes, care must be taken to ensure that the sound produced from the bandura remains aesthetically beautiful, and noble. 
Therefore, one of the main tasks for a bandurist is to produce a deep, capable of the most nuanced, "vocal" sound with all of its innumerable gradations, which is an important factor in the formation of a highly professional bandura performer.

\section{Peculiarities of Bandura Technique Formation}

One of the leading expressive means that dominates the artist's arsenal is the stroke. As a result, during the entire historical period regarding the development of professional bandura performance, the attention of performers, researchers, and methodologists was drawn to the problem of finger stroke technique. The scientific and methodological literature for the bandura has not yet created a system of common terms for different types of strokes. The conceptual certainty in the stroke terminology will contribute to the adequate realization of the composer's design, as well as the formation of a bright individual manner of the performer, because it is related to the choice of strokes. The individual manner of fingering determines the creative face of the interpreter. The complexity and multidimensionality of this problem lead to an attempt to classify bandura strokes, to find a unified approach to their systematization on specific grounds.

In musicology, the concept of "stroke" (germ. - Strich - trait or stroke) since the description of "strokes of the bow" by L. Auer has undergone a considerable evolution, until it was defined, first of all, as an artistic phenomenon, which is achieved by appropriate technical means.

It should be emphasized that an individual sound, whatever its characteristic form, is not a carrier of tone content. Only in the combination (through transients) of two or more sounds that have similar or different characteristic forms, can a performer unlock the interpretation. Without claiming comprehensive coverage of the issue, let us try to determine the basic principles of classification of bandura strokes.

Analyzing the performance and pedagogical experience, as well as the stroke symbolism in the music literature, we define the system of strokes according to M. Davydov, which consists of two main groups: strokes with different nature of connectedness and separation of sound (legatimo, legato, non-legato, staccato, staccatimo); strokes with different character of sound attack (detache, marcato, sforzando, portamento, portato). The conditionality of the distribution of strokes into groups is quite obvious. First, in real sound, both connected and separate execution is impossible 
without the nature of the attack. The nature of the sound attack depends on the degree of impact on the string. A number of sounds made non-legato piano first, then followed by forte, in the first case will have a softer, and in the second - a clearer, more emphasized attack. Thus, according to the classification we have adopted, the same method of separate execution is practically given two separate stroke names. One of them characterizes the kind of connection of sounds, the other has a dynamic meaning, for example: non-legato - detache; non-legato - marcato; non-legato sforzando and others. Secondly, in the process of performing by organic combination of various dynamic articulatory-rhythmic and timbral means on the bandura, as well as on other instruments, there is an unlimited number of stroke shades. The list of these bandura strokes, which have been widely used in practice, should not be considered as a mechanical transfer to the bandura of piano or violin techniques. The common terminology is used here to refer to the nature of expressive means in specific instrumental conditions.

As a result of the natural ability to play the bandura, the dominant role in bandura articulation is the legato stroke. The term legato means a smooth, continuous, "fused" performance of individual sounds, in which each note of the melody is most fully sustained. If on most instruments (piano, violin, domra, bayan) the previous sound is discontinued at the moment of taking the next one (due to articulation), then on the bandura the previous sound "continues" at the moment of taking the next one. The specific fineness of the extracted sound, when the string, without a special muffling motion, vibrating and damping naturally, creates a different nature to the banding nature of the bandura. Legato is the main articulation colour on the bandura. As noted above, when performing a passage on the bandura from the technical side, it is impossible to cut off the previous sound, so the articulatory clarity in combination with the appropriate accentuation (according to the dynamic contours of the melody) of the next sound becomes especially important.

The most acceptable form of motion is legiero. The basic conditions of execution are the followings: independence of fingers and their timely readiness to pluck a string, obligatory resting of a finger on a string before the pluck, maintaining in the bundle the constant sensibility necessary for the "creating" and at the same time of a sensory attack. This specific sensuality is associated with the feeling of lightweight coming from the direct support of the fingers - the wrist; coordination with a free but assembled, ready-to-use wrist; a stronger colour requires the support of a larger source of strength - the forearm and shoulder; the 
constant desire for ever faster pre-positioning of the fingers on the strings and the economy of the preparatory movements; continuous activation of auditory attention aimed at matching the volume of the extracted sound with the expressive content of the melody.

If the passages performed legato sound lightly on the bandura, pearly and at the same time soft, "velvety", it is difficult to obtain legato due to the natural gradual attenuation of each sound at a very slow tempo, as well as when performing longer-scale durations.

Legatissimo on the bandura - an expression of the ultimate fusion of performance, different from a slightly deeper sound flow and softened attack. The implementation on the bandura of legitissimo is directly dependent on the duration of sound, tempo and dynamics.

At a slow tempo, the natural damping of the string vibration makes it impossible to touch adjacent sounds, as in the case of longer-scale durations. Large dynamic gradations require lightning attacks, and as a result, sound injections that destroy the fusion of sound.

Therefore, the use of this touch is appropriate for improving the flight, singing sound, which increases the direction of the passage to a certain point, enhances the pedaling of the overall sound, and helps to integrate the integrity of the embodiment of melodic constructions. Improving the performance in legitimo, it is necessary to develop the elastic mobility of the fingertips. Hand, wrist and fingers should be absolutely light, free and supple. The pads of the fingers, dig deep into the strings with a lightweight, "intangible" finger weight, are resilient but softly set the strings vibrating. Carl Czerny's view that "in the musical of performance legato is the rule is, all other means are exceptions," can serve as a credo of bandura stroke technique.

Strokes with a distinctive sound can be firmly classified in bandura technique to the category of exceptions. If most instruments achieve staccato with the cessation of the sound-producing action (breathing, movement of the bellows, the interaction of the finger with the keys, movement of the bow, etc.), the bandura staccato requires additional movement in order to stop the vibration of the string. The bandura staccato is a sound burst that is achieved by a sharp attack and muffling (if necessary - immediately) of the string. Bandura staccato has two varieties - finger and wrist, and is determined by the nature of the work, its texture and tempo. The finger staccato is used for extraction of blatant sounds, it is made by light, mobile and elastic fingers. The playing finger is restrained into the string before the sound extraction by the tip of the finger; the string "breaks" with a pinch or blow easily but firmly; the 
adjacent finger quickly covers the vibrating string with the tip. In this way, the staccato provides sound volume, economy, accuracy, the precision of movements, promotes evasion, effective at a fast pace and various dynamic gradations in a single note writing. The wrist staccato is used in the performance of thirds, sixths, octaves and chords. The hand and wrist are completely free, supple, and ready for action. The nonplaying fingers are barely raised, the playing fingers (in accordance with the dynamics) are tufted more or less into the strings. A pluck (or strike) is made with a repulsive movement, the brush easily flies (bounces) over the strings with one continuous, smooth and directional movement and drops with the fingertips on the vibrating strings.

If the staccato is peculiar to some degree of brevity, acuity, suddenness, fragmentation of sound, then non legato is seclusion, greater sympathy, it can be classified as an extended staccato. Endurance duration and caesura may vary depending on the artist's artistic intentions. The bandura non-legato is used to emphasize sound resilience, is used in works of energetic, assertive, or soulful, thoughtful nature, and certainly enriches bandura sound resources.

Creative practice demonstrates that within the performing process there exists a mutual influence between these skills. It is known that all varieties of staccato are characterized by dashedness, isolation and that for legato -we have the coherence of the sound line. This, however, does not mean a complete absence of common features, both in manner and in the way of embodying allegedly opposite articulatory shades: the element of connectedness in the separate sounds of non-legato and staccato on the one hand, and the element of resolution in the legatissimo and legato - on the other side. A connection is manifested in the generalized nature of the motion (equal, accelerating, decelerating). The cohesive motion resolution is manifested in the even dashed character of the attack of the sounds that make up the dashed line. The interpenetration of the character of the sound of the strokes suggests that there is no endless boundary also in the technical methods of execution between the legato and the staccato, to legitissimo and non-legato. Undoubtedly, a similar technique of sound extraction - elastic and accurate plucks or hits-by bandurist uses both legato and staccato in their playing. The difference is in the length of duration. Both legato and staccato require rapid, pluck-independent, finger movements. Both techniques involve the positional preparation of the fingers at the time of plucking or impact. The only difference is that the legato requires only sound-producing movements, and the staccato also requires the damping 
movements of the fingers (or the side of the palm) by which the sounds are stopped.

Speed, velocity, independence of movement of the fingers include the accuracy of attack coming from the playing of staccato, and consistency as an element of connectivity - from the legato. So, with the acceleration of the tempo, we observe the interpenetration of elements, legato and staccato. The maximum staccato speed is made possible by the unity of the movements generated by the legato. Conversely, a movable legato with a characteristic elasticity of attack is possible with sufficient clarity, which is used in the staccato.

The term detache, which means "separate", "detached", is used to refer to the sound production of single sounds with a soft attack. The stroke is borrowed from the practice of playing stringed instruments, where it means the extraction of sounds by individual smooth movements of the bow. Paying attention to the characteristics of the stroke on the technical side of the performance, should not be ignored most importantly - the smoothness of movement, which is associated with a gentle manner of attack and determines the artistic value of this stroke on both the violin and the bandura. Unlike the cohesive legato, when performing detache, individual sounds are separated by the muting movements of the tips of the oscillating vibrating string. This distribution is accompanied by the inevitable, almost imperceptible pause. The detail on the bandura includes three elements: a soft dipping of the finger into the bottom of the string; soft repulsion from the string by the pluck; muffling by the fingertip of the vibrating string. The main point is the accentuation achieved by the expedient activity of the fingertips, and the weight playing, which created the pressure on the string to give it the necessary dense vibration. Lack of coordination leads to sharp accentuation, to the "breaking" of the string.

The reception of detache is a complex collection of movements, which are coordinated and similar in character but different in energy consumption and movement. The muscles of the fingers and hands that perform the sound-producing function pulse more vigorously, more diversely than when performing the pausing action. Mastering the stroke requires prolonged slow-speed repetition, while maintaining strict auditory-motor control. Marcato - stressed solid attack. The mark of the marcato is intended for use. purposefully and reasonably directed energy concentrated in the attack of the sound. In the forte or fortissimo mode, the clarity of the attack of individual sounds corresponds to the desired quality of marcato. However, playing the piano in this way requires 
a softer attack. The marcato technique requires the fingertips to be rigid, providing an energetic pluck (or hit) from the tip of the nail. The stressed attack requires the pre-positioning of the fingers with the tips on the strings. This will help to avoid nail tones, "buzzing" of strings, and the attack will become more specific. The repetition of the stroke requires the repetition of a set of movements. When you change the dynamics, the nature of the hand remains, the only difference will be the intensity of muscle pulsation. Thanks to this, at any dynamic level (from pianissimo to fortissimo), the stroke gives the sound of activity. The stroke of marcato is used in music of solemn, energetic, heroic, marching or dancing character, an example is M. Dremliuha's "Poema-Rhapsodia".

The use of sforzando indicates the need for the enhanced dynamic accentuation of individual sounds. This effect is borrowed from the orchestral manner of highlighting by using the "tutti" at the beginning of the duration and keeping the sound for the part of the duration that remains with only one group of instruments (for example, woodwinds). The bandura sforzando, as an active highlight of the attack with the subsequent damping of sound, is used with different dynamics and may have different shades: sforzando-piano, sforzando-forte and others. This stroke requires a certain minimum sound duration, which would allow the two levels of sound volume to be compared. The difference between the attack and the sound of the main part of the duration is minimal, conditionally measured by one step of conventional dynamic gradations. With a general piano attack, a mezzo piano is obtained. The bandura sforzando, made by a blow or a pinch, sounds bright and colourful. It is known that the excitation of the string by the nail (plectrum) produces many rapid oscillations of short waves, which determine the sharper timbre. Therefore, to achieve accentuation of the pluck or stroke must be performed with nail support. This will provide the effect of a "lightning bolt" followed by a gradual natural decay of volume. Thus, the main task of reproducing the sforzando and its dynamic and agogic hues related to the nature of the attack rests on the firmness and at the same time the elasticity of the fingers. To master this stroke, the player should train at a slow tempo, seeking the sharpness of muscular reactions, accurate dosage of strength and duration of the accentuated part of the sound in various dynamics. At the same time, the technique of muscle relaxation should be improved at the correct moment. All this is varied both in dynamics and muscle tone, the work of the lower periphery should be carried out against the background of expedient application of weight playing and economy of the amplitude of movements. Sforzando is 
widely used as a means of emphasizing a coherent melody or individual sounds against another texture.

In addition to the types of connected and separate articulations discussed above, one of the most difficult strokes - portamento, deserves special attention. It reflected and combined the basic contradiction that is the driving force of all articulation processes, namely: the contradiction between the two extreme poles of pronunciation - connectivity and resolution.

Portamento on a bandura means a combination of finishing detache, marcato or staccato (sforzando) in a single semantic group with a maximum endurance of the lengths. Therefore, portamento does not refer to individual sounds but to a group of notes as an expression of a particular musical thought. There are various shades of portamento on the bandura: soft, delicate, decisive, grotesque or sharply emphasized, sharp and so on. Most often, this stroke occurs at a moderate and slow pace, which allows you to bring to the listener a full range of articulatory-dynamic gradations characteristic of a particular nuance of portamento. Portamento - a combination of soft attack sounds in a single phrase. The highest sound power on the bandura is achieved at the time of the sound attack (except for tremolo), so the soft pulsating attack at the realization of this stroke ensures the separation of sound, and the vibration of uncovered strings creates a sound fusion. Reception involves the unity of the following movements: the fingers are soft and at the same time firmly dipped into the strings; the strings are given the direction of oscillation in the plane of the line in parallel to the soundboard, with an elastic repulsive movement. The moment of repulsion from the string is dominant in the inertial movement of the hand - a soft, "spring" pinch causes a single smooth "breathing", the coordination of movements of the hand, forearm, the whole apparatus, as well as the appropriate sense of weight, which provides proper contact with the pads.

It is clear that the above principles of applying strokes to the disclosure of artistic image should not be taken literally, because they are directly dependent on the articulatory aesthetics of the particular work performed. But to determine that in the keyboard performance of the Baroque era was dominated by the non-legato, and in early Viennese classicism staccato, and that the articulation of romanticism is characterized mainly by the principle of connected playing, then this does not mean the need to impoverish the articulatory-stroke reducing it to a single type. On the contrary, such an understanding should diversify 
the use of the same touch when interpreting the music of different historical periods and artistic directions. Thus, in the baroque legato, there will always be an element of limitation of each sound, in the passages of Mozart, played with legitimacy, the articulatory clarity of the rhythmic pulse of the smallest duration will be preserved, in the romantic staccato -it is the singing of the tone.

Such awareness of stroke, as a complex sound-forming complex, should underlie the modern solution of the articulatory-barrier problems of bandura pedagogy and performance.

The stroke area is not only limited to articulation, that is, horizontal, but also covers the vertical: dynamics, the internal rhythm of expressive means, and timbre-articulation sphere. Each of these expressive means within the stroke has its original (stroke) characteristic detection. The characteristic aspect of articulation, dynamics, internal rhythmic of expressive means, timbre and acoustic effects underlies the differentiation of strokes not only on the basis of "connected separately" or "extended - short", but also on the signs: soft, active, phonetic, in a certain rhythm-intonation, timbre, etc. It is on this basis that bandura strokes crystallize into a rich palette of varieties: attack, separate, connected, legato-based, connection-separated when shaking

The completeness and content of each stroke, as an artistic phenomenon, is determined not only by one feature, but by the unity of expediently directed, concentrated expressive means, which characterizes it as an embryo of specifically spoken music, which includes, in addition to the mentioned qualities, also metrorhythm, and the dynamics of the process development. Thus, the term as a synthetic term is wider, more content than the articulation of binding and separation of sounds.

The methodological basis for the classification of strokes is the dialectical unity of a set of sound expressive means - articulation, dynamics, internal rhythm and timbre in strokes. Thus, the complex concentrates on the artistic and expressive qualities of the sound of the bandura.

\section{CONCLUSIONS}

Summarizing the results of the proposed study, we have outlined the following positions:

- complete detection of the content of the performed work, its character, style features can only be reproduced by having an arsenal of expressive means of performance, namely: intonation, dynamics, timbre, fingering, strokes; 
- the sound of the bandura, as defined by artistic quality, is found to affect the hearing volume and mass attained at t- a number of practical recommendations are given on forming the skills of concentration of attention on different planes of the instrument he time of the attack;

- a comprehensive approach to the formation of a multidimensional view of the bandurist technique is proposed. This complex includes: rational use of hand weight; applicative orientation; understanding the arrangement of intervals and chords on a string; development of orientation-touch communications; systematic applicative-auditory coordination in the representation of bass and main string;

- the technique of mastering cohesive and separate strokes on bandura as a means of artistic expression is proposed; the touches concentrate on the distinctive qualities of bandura sound as a result of a set of basic techniques, skills and abilities; the performance of melodic lines should not be performed outside the specified line colour; ability to listen and make voices as solid dashed lines - one of the most important tasks of forming the professional skills of a performer; performing technique in the broadest, most general sense and in all the variety of individual techniques, skills and abilities is a phenomenon of the artistic.

Therefore, one of the main tasks for a bandura player is to produce a deep, capable to the maximum possible nuance of "vocal" sound with all its innumerable gradations, which is an important factor in the formation of a highly professional bandura performer. Bandura technique does not exist outside the interpretation of the artistic content of the performed music piece.

Outlined issues are not limited to the proposed study. It is especially relevant at the stage of dynamic development of the modern music space, and therefore needs further scientific research.

- The technique of mastering the bandura connected and separate pickings as a means of artistic expression is proposed; there are the distinctive qualities of bandura sound in the pickings as a result of a set of basic techniques, skills and abilities; the performance of melody lines should not be performed outside the given pickings; listening and sound skills to perform single picking line is one of the most important tasks of forming a professional skill of the performer; performing technique in the broadest, most general sense and in all the variety of individual techniques, skills and abilities is art.

Therefore, one of the main tasks of a bandura player is to provide a deep, capable to the maximum possible shading of "vocal" sound with all its innumerable gradations, which is an important factor in the formation 
of a highly professional bandura player. Bandurist technique does not exist outside the interpretation of the artistic content of the performed musical work.

Outlined issues are not limited to the proposed study. It is particularly topical at the stage of dynamic development of the modern music space and therefore requires further scientific research.

\section{SUMMARY}

Understanding the phenomenon of bandura art, the evolution of the basic laws of the acoustic capabilities of the instrument and features of sound production, an awareness of the principles, forms and methods of education of bandura professional, are urgent questions of scientific research of today. The purpose of the study is to theoretically substantiate the performance aspects of bandura sound production, which, due to historical and cultural characteristics, rely on the academic performance model.

The methodology of the research is based on the application of musicological, analytical and performer-interpreting approaches. Scientific novelty lies in the complex coverage on the basis of scientific and theoretical understanding of the sound-forming processes of formation of the bandura player's mastery.

The research has made the scientific-theoretical analysis of the processes of forming the bandurist's mastery. On the basis of generalization of his own practical concert-performing and pedagogical experience, psychophysiological aspects of the bandurist's performing technique were revealed, a detailed analysis of the sound-making and sound-production on the banur was performed, the articulation and stroke means of the bandurist's performing skill were investigated.

\section{REFERENCES}

1. Chernetska N. (2018) Vykonavska tvorchist bandurystiv Volyni yak dzherelo formuvannia natsionalnoi samosvidomosti [Performing creativity of bandura players in Volyn as a source of formation of national consciousness]. Bulletin of the Kyiv National University of Culture and Arts. Series: Musical Art, vol. 1, pp. 90-100 DOI: https://doi.org/10.31866/2616-7581.1.2018.146253.

2. Davydov M. (1998) Kyivska akademichna shkola narodnoinstrumentalnoho mystetstva [Kyiv Academic School of Folk Instrumental Art]. Kyiv: Ukrainian National Music Academy Tchaikovsky. (in Ukrainian) 
3. Davydov M.A. (2010) Istoriia vykonavstva na narodnykh instrumentakh [Folk Instrument Performance History]. Lutsk: Volyn Regional Printing House. (in Ukrainian)

4. Dorofeeva V. (2016). Formuvannia suchasnoho muzychnoho stylovoho prostoru na prykladi tvorchosti ukrainskykh kompozytoriv [Formation of modern musical style space on the example of the creativity of Ukrainian composers]. Muzychne mystetstvo $i$ kultura [Music art and culture], vol. 23, pp. 260-268. DOI:https://doi.org/https://doi.org/ 10.31723/2524-0447-2016-23-260-268.

5. Dudchak V. (2013) Bandurne mystetstvo ukrainskoho zarubizhzhia XX - pochatku XXI stolittia: Monohrafiia [Bandura Art of Ukrainian Abroad of the 20th - early 21st Century: Monograph]. IvanoFrankivsk: Foliant. (in Ukrainian)

6. Khai M. (2015) Mykola Budnyk i kobzarstvo [Mykola Budnyk and kobzarstvo]. Lviv: Astroliabiia. (in Ukrainian)

7. Kokh I. E. (1970) Osnovy stcenicheskogo dvizheniia [The Basics of the Stage Movement]. Leningrad: Iskusstvo. (in Russian)

8. Kushpet V. (2007) Startsivstvo. Mandrivni spivtsi-muzykanty $v$ Ukraini XIX - pochatok XX storichchia [Eldership. Travelling Musicians in Ukraine the 19th - beginning 20th century]. Kyiv: Tempora. (in Ukrainian)

9. Kushpet V. (2016) Shkola rekonstruktsii vykonavskoi tradytsii (kobza, lira, torban, bandura, spiv) [School of reconstruction of the performing tradition (kobza, lira, torban, bandura, singing)]. Kyiv: Tempora. (in Ukrainian)

10. Martinsen K. (1977) Metodika individualnogo prepodavaniia igry na fortepiano [Methods of individual piano teaching]. Moscow: Muzyka. (in Russian)

11. Milshtein Ia. I. (1967) Sovety Shopena pianistam [Chopin's advice to pianists]. Moscow: Muzyka. (in Russian)

12. Mishalov V. (2013) Kharkivska bandura: kulturolohichnomystetski aspekty genezy $i$ rozvytku vykonavstva na ukrainskomu narodnomu instrumenti [Kharkiv bandura: Cultural and Artistic Aspects of Genesis and Development of Performance on the Ukrainian Folk Instrument]. Kharkiv: Publisher Savchuk O. O. (in Ukrainian)

13. Neuhaus G. (1988) Ob iskusstve fortepiannoi igry [On the Art of Piano Playing]. Moscow: Muzyka. (in Russian)

14. Oliinyk O. (2018) Domrove tremolo v aspekti rytorychnoho zmistu vykonavskykh pryiomiv hry [Domra Tremolo in Terms of the Performance Techniques Rhetoric Context]. Bulletin of the Kyiv National 
University of Culture and Arts. Series: Musical Art, vol. 1, pp. 57-66. DOI: https://doi.org/10.31866/2616-7581.1.2018.140573.

15. Omelchenko A. (1973) Shkola hry na banduri [A handbook for the bandura]. Kyiv: Muzychna Ukraina. (in Ukrainian)

16.Pukhalskii Ia. G. (1978) Metodika obucheniya igre na bandure [The technique of teaching bandura playing]. Kyiv: Goskonservatoriia. (in Russian)

17.Zinkiv I. (2013) Bandura yak istorychnyi fenomen: Monohrafiia [The Bandura as a historical phenomenon: Monograph]. Kyiv: The Rylsky Institute of Art Studies, Folklore and Ethnology. (in Ukrainian)

Information about the author: Broiako Nadiia, orcid.org/0000-0001-9109-1734 PhD in Arts, Professor Kyiv National University of Culture and Arts 36, Ye. Konovaltsia Str., Kyiv, 01133, Ukraine 
DOI https://doi.org/10.36059/978-966-397-197-1/153-172

\section{THE ART OF BOOK IN THE 17th-18th CENTURIES}

\section{Karakoz Olena}

\section{INTRODUCTION}

Total digitization of all spheres of life of modern society leads to the transformation of social and cultural processes. Under the influence of digital technology, a new artistic space is being formed. In such conditions, art as a universal form of mirroring the man's inner beauty, which influences on the formation of the society's spiritual development and thus contributes to the humanistic orientation of all spheres of civilization, acquires special significance. In the process of its development, art enriches with new pieces of art, and each of them has a stamp of time.

There was a special cult of a book in ancient times. The publications were kept very carefully, treated as great value and even as a sacred object. Partly it can be explained that it took months to compose one book because each edition was done manually. The cost of materials, finishing and decoration of books was also of great importance - the books were made to be attractive, so they were often decorated with precious stones and metals, hand-paintings, etc. They always had a symbolic meaning. Respect for books in world culture cannot be overestimated. A book is a complex phenomenon of culture and art. $^{1}$ It was and still is a natural element of European civilization, one of the main specific features of this culture. ${ }^{2}$

A book has always being advanced simultaneously with society and embodied its main achievements; it was always a reflection of those events that took place in the social, cultural, political life during the historical development of human civilisation. On the other hand, the progressive development of society, its growing intellectual demands has

1 Karakoz O. O. (2019) Tradytsiina knyha - fenomen suchasnoho sotsiokulturnoho prostoru [The traditional book is a phenomenon of modern sociocultural space]. Library Science. Rekord Studies. Informology, no. 3, p. 95.

${ }^{2}$ Hrypych S. (2011) Knyha yak osnova rozvytku dukhovnoi ta intelektualnoi kultury liudyny [The book as a basis for the development of spiritual and intellectual culture man]. Bulletin of the Book Chamber, no. 9, pp. 1-3. 
improved the technology of book production and the organisation of its distribution. Each element of its decoration and finishing is a painstaking work of peoples for centuries. After all, such a wonderful acquisition of human culture, as a book, was created not immediately and not by virtue of some genius, but as a result of the long-lasting progress of entire nations, via the difficult way of survival and knowledge the essence of their own being. ${ }^{3}$

Precisely because of the centuries-long work by prominent artists the art of the book has emerged - a field of artistic activity aimed at creation of a book as an art visual form of expression of a work ${ }^{4}$ and one of the highest cultural achievements of humanity, the unity of spiritual and material culture. ${ }^{5}$ The masters of the book design, especially in the 17th-18th centuries, did a lot for the general exaltation of the fine arts and laid the basic traditions of the art of the book, which have been further developed in modern design and printing art.

The best works of book graphics became a valuable asset of the common treasure-house of European culture. The art of book design is intended not only to create an artistic image that should please the reader with its beautiful and attractive appearance, first of all, but it should also be a great and sincere friend, an assistant of a reader. The illustrations of the book, its font design, decoration, ornamental decorations everything that we call book graphics - actively help the reader to understand the literary work, its artistic images, enriches it ideologically. ${ }^{6}$

The modern world of digital technologies transforms gradually a printed book from a source of information to a work of art and an object of collectors' attention. The availability of information and the spread of electronic analogues of the book set new challenges not only for

\footnotetext{
${ }^{3}$ Karakoz O. O. (2018) Istoriia knyhy [History of the book]. Kyiv: Lira-K.

${ }^{4}$ Markova V. A. (2009) Mystetstvo knyhy: komunikatyvnyi aspekt [The art of the book: the communicative aspect]. Visnyk Kharkivskoi derzhavnoi akademii kultury, iss. 28, pp. 100-106.

${ }^{5}$ Halynska H. I. (2019) Rol khudozhnyka v knyzi dlia ditei [The role of the artist in a book for children]. Proceedings of the Khudozhnyk $i$ knyha (Ukraine, Kyiv, May 7, 2019) (eds. Chebykin A. V., Yakovliev M. I., Bitaiev V. A., Perevalskyi V. Ye., Fedoruk O. K., Berdynskykh S. O., Kharchenko P. V.), Kyiv: Natsionalna akademiia mystetstv Ukrainy, p. 7.

${ }^{6}$ Hapon Yu. Ya. (1967) Mystetstvo oformlennia knyhy - vazhlyvyi faktor estetychnoho vykhovannia [The art of book designin is a very important factor of the aesthetic education]. Printing and Publishing, no. 3, p. 147.
} 
publishers but also for the artists involved in the design of the printed products. In this context, various author's tools for the creation of art books are actively developed, among which the principle of synergy is implemented, as the interaction of different parts within the objets d'art.

\section{The Art of Book in the 17th Century: the Main Innovations and Changes in the Illustration Technique}

Belarusian first pressman Frantcysk Skaryna pointed to the communicative function of the art of book decoration, the use of which for a printed book is necessary for "better perception" by a reader. Although this activity is inherent to the book in one way or another since its emergence (the search for the most appropriate form for a particular culture), it received its theoretical foundations only in the 20th century. The outstanding master of illustration and the theorist of book art V.A. Favorsky considered that the art of book is synthetic art, the task of which, first of all, is in the spatial representation of the work, which moves in time, that is, in the organisation of the movement of the work in a certain rhythm. This was exactly what the book design should have been aimed at. V. Markova states: "The mentioned ideas are of great importance for understanding of the communicative nature of a book because each element of the book ensemble is perceived by V.A. Favorsky namely in the context of transferring of the text movement, which should be appropriately embodied in the rhythm of the book design: all elements of a book - a cover, a flyleaf, a title, separate pages, a headpiece, endings, illustrations - organise movement within it, as they mark the beginning and the end, as well as its partitioning in a certain way". The most consistent theory of the art of book as a means of communication in the 70s of the last century was developed by V.M. Liakhov. It is embodied in the model of the functional structure of a book, where a book is shown as a complex and multifaceted system based on the functional interaction of links of the elements taken in relation to the man - the consumer of the book. If traditionally the task of creation of a book ensemble was to combine three components: aesthetic,

${ }^{7}$ Lutsyshyna D. V. (2019) Pryntsypy synerhii u tvorenni ta prezentatsii art-knyhy khudozhnytseiu A. Komarovoiu [Principles of synergy in the creation and presentation of art books by artist A. Komarova]. Proceedings of the Khudozhnyk $i$ knyha (Ukraine, Kyiv, May 7, 2019) (eds. Chebykin A. V., Yakovliev M. I., Bitaiev V. A., Perevalskyi V. Ye., Fedoruk O. K., Berdynskykh S. O., Kharchenko P. V.), Kyiv: Natsionalna akademiia mystetstv Ukrainy, pp. 13-14. 
communicative and material and technical, then V.M Liakhov considered that the aesthetic nature of the book organism lies precisely in its communicativeness, i.e. the ability to convey the text message as much as possible. ${ }^{8}$

The new definition "book design" was introduced in the middle of the 20th century. In the monograph of the well-known Ukrainian researcher B. Valuienko The Book of Architecture, such components of a book were analysed as the design of the book block, variants of the combination of a strip of a set with illustrations, font typography, etc. V. Liakhov, $\mathrm{Yu}$. Herchuk and other art historians also studied this field. In the second half of the 20th century, the idea that the architectonics of a book is the basis of the coexistence of all its components asserts gradually, presents a book as a unique synthetic object that combines different types of arts: literature, fine arts and abstract sign systems (font and ornament). Touching the materials of the cover, the texture and the colour of the flyleaves are made of, the book block paper, the process of page-turning, compliance with the point types of composed fonts, technique of illustration execution, even the colour of the bead and bookmark in the artist's hands - the book masters work for the content, idea and literary style of the artist work. ${ }^{9}$

At the same time, as it is known, the highly professional use of different artistic languages in a single work - the combination of the creative intent of the text creator with the publication design by the artist, illustrator - increases greatly the artistic value of the printed edition. The task of all participants of the publishing process is a masterful combination of the form and content of the artistic image, the creation of such a holistic, bright, perfect and, at the same time, a modern printed edition, that will be able to interest the potential target audience - those

${ }^{8}$ Markova V. A. (2009) Mystetstvo knyhy: komunikatyvnyi aspekt [The art of the book: the communicative aspect]. Visnyk Kharkivskoi derzhavnoi akademii kultury, iss. 28, pp. 100-106.

${ }^{9}$ Mitchenko V. S. (2019) Pro maibutnie paperovoi knyhy [About the future of the paper book]. Proceedings of the Khudozhnyk $i$ knyha (Ukraine, Kyiv, May 7, 2019) (eds. Chebykin A. V., Yakovliev M. I., Bitaiev V. A., Perevalskyi V. Ye., Fedoruk O. K., Berdynskykh S. O., Kharchenko P. V.), Kyiv: Natsionalna akademiia mystetstv Ukrainy, pp. 15-16. 
who should buy it and get acquainted with the content getting positive aesthetic emotions in the process of perception of information material. ${ }^{10}$

The seventeenth century was characterised by intensification of the political struggle, activation of the democratisation of society, which required the publication of a large number of cheap editions. The $17^{\text {th }}$ century is characterised by significant cultural prosperity in Europe: universities, colleges, various schools are established in many cities, and the number of educated people rises significantly not only among the prosperous and middle classes of society but also among the common people.

Under these circumstances, the book began to be in demand. While the books were published mostly in Latin in the 15th and the first half of the 16th centuries, then the publications in the national languages English, French, German, Italian, Dutch, etc., prevail at the book market. And if in previous times the major percentage was for religious publications, aimed at a small number of educated readers, then in the 17th century the flow of political books, brochures and leaflets appeared and grew rapidly. The readers were provided with another, more popularized book. It was published in the national languages of different countries. One of the first works published in France in the national language, not Latin, was François Rabelais' book The Life of Gargantua and of Pantagruel. According to the contemporaries, it was sold out in a large number in two months. At this time, Shakespeare's books are published in England, Corneille's, Moliere's, and Racine's ones - in France, Lope de Vega's, and Calderon's books in Spain. The frolicsome novel replaces the knightly novel (the gallant novel is a genre of French and German literature of the mid-seventeenth century, which combines elements of knightly and Hellenistic novels. These novels use various materials, particularly taken from ancient historians). The novels of Cervantes, Scarron, Lesage, and Sorel were published in large numbers. The popularity of the genre was unbelievable. A five-volume novel by Madeleine de Scudery Clelia

${ }^{10}$ Kharchenko P. V. (2019) Novyi etap rozvytku syntezu mystetstv v oformlenni suchasnykh drukovanykh vydan [A new stage in the development of synthesis of the arts in the design of modern printed editions]. Proceedings of the Khudozhnyk $i$ knyha (Ukraine, Kyiv, May 7, 2019) (eds. Chebykin A. V., Yakovliev M. I., Bitaiev V. A., Perevalskyi V. Ye., Fedoruk O. K., Berdynskykh S. O., Kharchenko P. V.), Kyiv: Natsionalna akademiia mystetstv Ukrainy, pp. 31-32. 
(1662) might seem boring today, but at that time it was sold in huge circulation.

Complex relationships and struggle of social forces generate also a variety of artistic and ideological trends. Despite previous historical periods when art developed in the framework of homogeneous styles (Romanesque and Gothic), in the fine arts, together with traditional mythological and biblical genres, the secular one occupies the dominant place: domestic genre, landscape, portrait, and still-life paintings.

The 17 th century became a major factor in the formation of national cultures of Modern times. In this period, the process of localisation of large national schools, whose originality was determined both by the conditions of historical development and the artistic tradition in each country - Italy, Flanders, Holland, Spain, France - comes to an end. This allows us to consider the 17th century as a new stage in the history of the fine arts, characterised by the dominance of two great styles - baroque and classicism, elements of which are vividly expressed in book culture.

Both baroque and classicism are characterised by a desire for generalization, but the masters of the baroque tend to the dynamic masses, to complex unfolded ensembles and the features of these two great styles are often intertwined in the art of one country, and even in the work of the same artist, giving rise to contradictions in it. Along with baroque and classicism, in the fine arts, there is a more direct, more strong and realistic reflection of life, free from stylistic elements. The realistic direction is an important milestone in the evolution of Western European art. Its manifestations are extremely diverse and striking both in different national schools and in some masters of the book arts. ${ }^{12}$

At the same time, significant changes take place in the art and technique of illustration: the transition from xylograph (engraving on wood, where relief lines are printed over the form) to engraving on copper and letterpress. ${ }^{13}$

The printing technique became more complicated, and the technological integrity of a book, printed before along with illustrations and decorations from a single form, was violated. Now the illustrations

${ }^{11}$ Karakoz O. O. (2018) Istoriia knyhy [History of the book]. Kyiv: Lira-K, p. 265.

12 Yeroshkina O. O. (2017) Epokha baroko [The Baroque Era]. Kharkiv: O. M. Beketov Kharkiv National University of Urban Economics, p. 120.

${ }^{13}$ Karakoz O. O. (2018) Istoriia knyhy [History of the book]. Kyiv: Lira-K, p. 266. 
are printed separately (using another machine), usually on separate insert sheets, and place them between or after the pages of the text.

Meanwhile, this selection of graphics contributed partially to the architectonic clarity in the construction of the main text line. Now the placement of certain images in the text doesn't disturb its integrity, which was characteristic when printing xylography illustrations. The unified integrity and symmetrical structure of both the individual page and the uniformity of all pages as a whole became clearer in books. ${ }^{14}$

Developing the traditions of the Renaissance mainly, the artists of the 17th century expanded their interests and deepened the cognitive range of art greatly. Compared to the Renaissance, the Baroque era is more complex in its content and artistic forms. The integral poetic perception of the world, characteristic for the Renaissance, is destroyed; the ideals of harmony and clarity are unattainable. However, the image of a person remains invariably in the spotlight of artists. Its embodiment becomes more concrete, emotional and psychologically complex. ${ }^{15}$ The increase of interest in the individual personality, all features of his physical image and character, and special attention to the man's inner world have caused in many countries the incredible rise of portrait art, in particular the development of psychological portrait. ${ }^{16}$

The portraits of authors are begun to depict on the frontispieces of books that conveyed the textural and plastic variety, the elegance of Baroque painting. In the book of the 17th century, an engraved cover sheet preceded a typed one, depicting a complex spatial composition that conveyed the content of the book in an allegorical form. Its structure resembled a solemn altar or a triumphal arch, which allegedly opened the way to the space filled with various allegorical images. ${ }^{17}$ The copperengraved frontispieces, title pages and other graphic ornaments were filled with lush, three-dimensional shapes, made in the spirit of aesthetics

${ }^{14}$ Gerchuk Yu. Ya. (2000) Istoriya grafiki i iskusstva knigi [The history of graphics and book art]. Moscow: Aspekt Press, p. 192.

15 Yeroshkina O. O. (2017) Epokha baroko [The Baroque Era]. Kharkiv:

O. M. Beketov Kharkiv National University of Urban Economics, p. 120.

16 Yeroshkina O. O. (2017) Epokha baroko [The Baroque Era]. Kharkiv: O. M. Beketov Kharkiv National University of Urban Economics, p. 7.

17 Gerchuk Yu. Ya. (2000) Istoriya grafiki $i$ iskusstva knigi [The history of graphics and book art]. Moscow: Aspekt Press, p. 193. 
of the so-called Great Style. ${ }^{18}$ The famous artists made such compositions of titles. Thus, B. Moretus' publications, C. Plantin's successor, were designed by one of the most prominent painters of Flanders - Peter Paul Rubens. ${ }^{19}$ The characteristic feature of his work was the combination of realistic moments with mythological figures and allegories. $^{20}$

Changes happen in binding art too. In the 17th century, first France, and later other countries, became fascinated with dotted style (pointille) covers, which was started by the French bookbinder Le Gascon in 1620. His technique of decoration of leather covers was characterized by the fact that the ornamental and decorative motifs were composed not of thin lines, but of small dots, which formed thin lines. With the help of cover gilding technique, the masters made complex and at the same time delicate decorative patterns. The European countries borrowed quickly the means of cover decoration, started by Le Gascon: in the Netherlands, pointille was used in the design of Elsevier editions, which were "dressed" in green marocain; in England, dotted decorations were made in combination with stylized images of tulips and other flowers and plant forms. In the second half of the 17th century, various embossing stamps, made in the Le Gascon spirit, were sold at fairs in European countries. At this time, books were mostly printed in letterpress. It was distributed in the printing industry until new tools appeared. A huge number of publications were printed in letterpress - books, magazines, letterheads, illustrations etc. The exceptional versatility of this method is one of the positive factors; however, this method has a number of negative features, including the complicated production of the printing form, and the reproduction of these forms in the case of numerous replications. ${ }^{21}$

The Elseviers family became famous among the Dutch publishers, some of whom were merchants, and others were printers in different cities of the Netherlands and England. The Elsevier Company, founded by Lodewijk Elsevier, existed from 1581 to 1712 . The numeral dynasty

18 Ovchinnikov V. (2005) Istoriia knyhy: evoliutsiia knyzhkovoi struktury [History of the book: evolution of book structure]. Lviv: Svit, p. 313.

${ }^{19}$ Gerchuk Yu. Ya. (2000) Istoriya grafiki $i$ iskusstva knigi [The history of graphics and book art]. Moscow: Aspekt Press, p. 193.

${ }^{20}$ Yeroshkina O. O. (2017) Epokha baroko [The Baroque Era]. Kharkiv: O. M. Beketov Kharkiv National University of Urban Economics, p. 78.

${ }^{21}$ Karakoz O. O. (2018) Istoriia knyhy [History of the book]. Kyiv: Lira-K, p. 266. 
of Lodewijk (1540-1617), Matthijs (1564-1640), and Bonaventura (1583-1652), Abraham (1592-1652) was known in all European countries due to the publication of scientific and educational books.

Elseviers first published scientific literature in Latin, later began to publish books in the national languages - French, Dutch, Italian, German, as well as Arabic and other languages of the East. They often produced educational literature and fiction: the grammar of French, German, Hebraic, Arabic, Spanish and other languages. It was in their publishing house that the first Galileo Galilei's work The Discourses and Mathematical Demonstrations Relating to Two New Sciences (1638) was published. $^{22}$

The Elsevier famous series The Republics (The States), which was published in 1625-1640 in small volumes from year to year for decades, became especially famous. The Elseviers met the objective needs of the market - made a book much cheaper. The general reader was not interested in the external appearance of the publication, but above all its content, high scientific information value and affordable price of a book. To do this, they reduce the size of the book to $1 / 12$ of a piece of paper (approximately 135 $\mathrm{mm} \times 72 \mathrm{~mm}$ ), making it of a pocket-size, but, at the same time, do not reduce the text size of the publication. Small formats existed before the Elseviers, but the printers used large x-height fonts and their books were too thick. The Elseviers invited van Dyck, a well-known engraver and bookbinder from Antwerp, who made special fonts for the firm with small $(6,7,8$ points), but with a very clear face. These wonderful fonts have made Elzeviers very popular. A quality and simple font for the small format editions, developed in their printing houses, was called Elsevier; it is still used in our time. The Elseviers have produced several miniature editions that demonstrated clearly the publishers' achievements in printing and the art of book design. In 1627, a miniature book On the Royal Law was published. The following year, The Aphorisms of Hippocrates were published, the size of this book was reduced to $92 \times 44 \mathrm{~mm}$, and the format of The Satyricon by Petronius (1677) was $88 \times 48 \mathrm{~mm}$. All Elsevier printing houses have designed the books quite well. They used engraved illustrations, decorative covering of titles. The composite complex graphic frontispieces were engraved by leading masters. The Elseviers, like Plantins, did not save money on the decoration of books. The small volumes of the Elsevier Company with magnificently engraved frontispieces and output sheets

\footnotetext{
${ }^{22}$ Karakoz O. O. (2018) Istoriia knyhy [History of the book]. Kyiv: Lira-K, p. 267.
} 
depicting publishing stamps - a hermit under a tree, Minerva under a tree, an eagle with arrows, a palm tree, a sphere (globe) quickly got to all European countries. The Elsevier Company reached its greatest prosperity in the second half of the 17th century when it opened a book publishing office in Amsterdam and numerous representative offices in big European cities. ${ }^{23}$

The combination of high-quality design with professional editing and cost reduction has become the main feature of Elsevier editions.

The reduction of the book size led to a decrease in the price of books and increased circulation. At the same time, the books became affordable not only to the feudal lords, but also to ordinary people - their cheap book could be bought by students, teachers, and peasants. The Elseviers' activities became a real revolution in the book market because they make the book a universal commodity. At this time it becomes fashionable to carry books with you and for this purpose, a "book pocket" appears in clothing. Therefore, it is sometimes said that the Elseviers opened the pocketbook era. When the publisher Daniel Elsevier died, philosopher J. Locke said: "His death is a social loss". 24

The Royal, the first state printing house of France was founded in France, in the Louvre on the initiative of Cardinal Richelieu, in 1640, in which the checked corrected liturgical books were produced. This powerful printing house had a wealth of font equipment: great antique fonts, Greek fonts, and fonts of Eastern countries.

One of the features of its activities was the luxurious book design. The splendour and solemnity were reflected in the Baroque style, which prevailed in the French fine arts throughout the 17th and the early 18th centuries and reflected the noble and ecclesiastical culture of the period of imperial absolutism of the royal power ${ }^{25}$ and characterised by bright and expressive ornament, splendour, magnificence, combined with a wild emotionality and pathetic. ${ }^{26}$

The Royal Printing House published a 10-volume edition of the Bible with stunning illustrations. In magnificent editions, it usually glorified the absolutist power of the church and the king. The Royal Printing House published works of ancient classics with popular science commentaries for the heir to the French throne. The series consisted of

${ }^{23}$ Karakoz O. O. (2018) Istoriia knyhy [History of the book]. Kyiv: Lira-K, p. 268.

${ }^{24}$ Karakoz O. O. (2018) Istoriia knyhy [History of the book]. Kyiv: Lira-K, p. 269.

${ }^{25}$ Karakoz O. O. (2018) Istoriia knyhy [History of the book]. Kyiv: Lira-K, p. 269.

26 Yeroshkina O. O. (2017) Epokha baroko [The Baroque Era]. Kharkiv: O. M. Beketov Kharkiv National University of Urban Economics, p. 8. 
64 volumes in quarto format. The luxuriously decorated books were printed on high-quality paper with large point types. In 1692, Louis XIV commissioned the creation of a new font for the Royal Printing House. The commission of the Academy of Sciences under the guidance of the mathematician Nicholas Jenson developed the drawing of this font. ${ }^{27}$ The chief engraver of the Royal Printing House, Philippe Grandjean, without following the drawings of the commission, produced a font with a greater contrast of strokes than in the fonts of the old antiques created by N. Jenson and C. Garamond. This font was called "Royal Antiques". The bibliophile Duke de Grolier, Minister at Francis I, initiated the whole school of bookbinding, known as "Grolier". The Paris master was the first who began to put the author's name and title on the spine of a book. $^{28}$

Ph. Grandjean's font was the first modification of the Baroque antique, and, from a historical point of view, it can be characterized as a precursor of the transitional antique - the group of W. Caslon and J. Baskerville's fonts, which are even more contrasting.

The Baroque style prevailed in French art throughout the 17th and 18th centuries. ${ }^{29}$

\section{The Art of the Western European Book in the 18th Century}

At the beginning of the 18thcentury, the "aristocratic editions" dominated at the book market, frivolous sensuality and a passion for various beautiful and magnificent things prevailed in fashion. Such editions were designed in the Rococo style (the Rococo is a reversed Baroque style, which in the second half of the 18th century reached (from France and Austria) Ukraine - Kyiv, Lviv in the 1760-79s. The creative driving force of the Rococo era in all sections of culture was espri, as opposed to sensibilite of the Baroque or reason (raison) of classicism. Rococo style is created for the woman and adapted to her changing, at that time, tastes and whims. Almost the main word of the Rococo era was the word "whim". In art, it is defined by light, nervous, gentle and intricate forms (playful rococo).

${ }^{27}$ Karakoz O. O. (2018) Istoriia knyhy [History of the book]. Kyiv: Lira-K, p. 269.

${ }^{28}$ Karakoz O. O. (2018) Istoriia knyhy [History of the book]. Kyiv: Lira-K, p. 270.

29 Ovchinnikov V. (2005) Istoriia knyhy: evoliutsiia knyzhkovoi struktury [History of the book: evolution of book structure]. Lviv: Svit, p. 313. 
The luxury of the publication and the insane circulation made these books very expensive. A characteristic feature of "aristocratic editions" was Euphuism, a term that originated from the name of J. Lyly's novel, Euphues: The Anatomy of Wit, famous at that time. ${ }^{30}$ It is an artificial, precious, and full of metaphors and various literary expressions language that was quite common in the salons. The basis of this novel is the story of an aristocrat's adventures of the 16th century who invents his linguistic style (for example: “... the greenest beech burns faster than the driest oak; the purest silk decays faster of all; the sweetest wine quickly turns into the most acidic vinegar"). J. Lyly's new prose immediately provoked a flood of imitation. For a long time the Euphuism style, decorative and a bit fanciful, was fashionable among the representatives of the English aristocracy. However, the story was not lost in the centuries, and if, six years after the first edition, the novel Euphues: The Anatomy of Wit was reprinted five times more, then in the 20th century, J. Lilly could not complain about the inattention of publishers. The famous artists of the time, Francois Bouchet, Jean-Honore Fragonard, were invited to create the illustrations. The engraving on copper was created by Pierre-Philippe Chauffard, Noël Lemire, Philippe Le Bas and others. Many books with wonderful illustrations were republished: La Fontaine's Fables, Ovid's Metamorphoses. During the years 1761-1798, M. Voltaire's The Maid of Orleans endured 16 reeditions. The books that were fully engraved appeared: both text and drawings on copper plates. The French engravers and artists reached a high professional level in the second half of the 18th century: the small illustrations were decorated with carved scenes with the smallest details, demonstrating the marvels of the engravers' technical skills. ${ }^{31}$

The dramatic shifts occurred in book design. The book changed its appearance: its format became narrow and elongated. The characters in rows on narrow columns began to get denser, however, using large leadings and wide book margins. Leading French letter-founder Pierre Simon Fournier (1712-1768) created new varieties of antique fonts, beautiful italics and decorative initials, as well as new cast ornaments from which small vignettes, headpieces and various framing could be composed. The book texts in the Rococo style were accompanied by numerous illustrations of erotic content made in copper.

\footnotetext{
${ }^{30}$ Karakoz O. O. (2018) Istoriia knyhy [History of the book]. Kyiv: Lira-K, p. 312.

${ }^{31}$ Karakoz O. O. (2018) Istoriia knyhy [History of the book]. Kyiv: Lira-K, p. 313.
} 
Such literature was presented by the works of ancient Roman and Greek lyricists Anacreon, Sappho, Bion, Moschos, the books of erotic content by F. Rabelais, Moliere, J. La Fontaine and others. ${ }^{32}$

The most outstanding painters of the era participated in the illustrative design of the books $-\mathrm{F}$. Bouchet, H. Fragonard. ${ }^{33}$

The prosperity of illustrative art enriched and polished the technique of engraving on metal, bringing it to a special sophistication, a variety of shades, colour solutions. The attempts were made to multicolour print images. The xylography technique was used in the decorative book design, especially when making flower headpieces, endings and other coloured ornaments. ${ }^{34}$

The peculiarities of artistic decoration and design of the book page of the spread, the title and the strip changes from the 17th-18th centuries only in some details.

The role of type ornament was enhanced, the main characteristic of which was certain mobility and rhythm of forms. The page was clearly traced by depicting the dividing lines used to separate and highlight the opening lines and divide the text into chapters. They were usually decorated with a simple ornament. The decorative framings were used to illustrate and decorate the cover sheets. ${ }^{35}$

Along with the fashionable "aristocratic" editions, printed in small formats on high-quality paper with numerous illustrations on copper, the modestly decorated books of famous Enlighteners - famous figures of the Enlightenment era were very popular. The stories and dramas of Voltaire, Goethe, Rousseau's novels, Shakespeare's tragedies, and Beaumarchais's comedies were democratic. The design of the editions of these authors was not marked by certain splendour, characteristic for aristocratic editions. The classicism found its reflection in the noble simplicity of proportions - the style that corresponded to the canons of

\footnotetext{
${ }^{32}$ Karakoz O. O. (2018) Istoriia knyhy [History of the book]. Kyiv: Lira-K, p. 312.

${ }^{33}$ Gerchuk Yu. Ya. (2000) Istoriya grafiki $i$ iskusstva knigi [The history of graphics and book art]. Moscow: Aspekt Press, p. 199.

${ }^{34}$ Gerchuk Yu. Ya. (2000) Istoriya grafiki $i$ iskusstva knigi [The history of graphics and book art]. Moscow: Aspekt Press, p. 200.

${ }^{35}$ Gerchuk Yu. Ya. (2000) Istoriya grafiki i iskusstva knigi [The history of graphics and book art]. Moscow: Aspekt Press, p. 201.
} 
ancient art. The Enlighteners' books were more accessible and cheaper than aristocratic ones.

The art of book design reached the greatest flourishing in France in the 18th century. Among the 18th-century French figures, the Didot family was the most famous representatives in the field of book, paper and printing production. The founder of the company was François Didot (1689-1757), which opened the printing house and the bookstore in Paris in 1713. In the second half of the 18th century, the Didot company became the most powerful in Europe and produced products for many countries. The firm developed and cast printing fonts, printed books and magazines, owned numerous bookstores. One of the sons of the firms founders, François-Ambroise Didot, perfected the vellum paper invented by the English printer, J. Baskerville, by replacing some of the wooden parts with metal ones; together with his son Firmin Didot, he introduced and set clear rules for the printing system of measures and European type-foundry started to use it. Having used the font graphics of the famous Italian artist G. Bodoni, F.A. Didot created a wonderful antique font, which was called the Didot antique. Firmin Didot was the first who used the process of stereotypography in printing practice (making the exact copies of the printed type-setting forms, with the help of which later new solid printing forms for replication were cast), which reduced significantly the cost of the book production process and the cost of one copy. Pierre Didot, Firmin's brother, became famous as the publisher of the magnificent "Louvre Editions". Dido's beautifully designed books competed with the books of famous Italian book printer G. Bodoni.Even at the International Book Exhibition in 1806, the three-volume edition of the works by J.B. Racine, published by P. Didot, was recognized as the best edition of the century and a masterpiece of book printing art. ${ }^{37}$

At the end of the 18th - first quarter of the 19th century, a new style the Empire - began to form in France, England and other European countries, which was formed on the aesthetics of the classic monumental forms of the imperial Rome and ancient Greek archaic (the Empire style is a continuation of the revolutionary classicism and Neoclassicism in general). The empire was more solemn and pretentious. Ancient Rome remained a model for artists, but now it is no longer a republican one, but

${ }^{36}$ Karakoz O. O. (2018) Istoriia knyhy [History of the book]. Kyiv: Lira-K, p. 313.

${ }^{37}$ Karakoz O. O. (2018) Istoriia knyhy [History of the book]. Kyiv: Lira-K, p. 314. 
an imperial one with its palaces and triumphal arches. The Empire style is characterised by a tendency to strict grandeur and pomposity, cold elegance and the exaltation of the absolute power of military monarchies (the first empire in France, Russian Tsar Alexander I. Military emblems, weapons of ancient Rome, laurel wreaths, winged griffins, sphinxes, lions, etc. were used in the decorative ornamentation of the architectural structures, furniture, etc). P. Didot's books of this period have fonts with even greater contrast between the basic and auxiliary elements, and the drawing of the letters has become more geometric. The art decoration in P. Didot's books, starting with typeface, type-setting, the makeup of columns and ending with the production of graphic ornaments and copper-engraved illustrations, has acquired cold reasonableness, harshness and academicism. The book formats increased significantly during this period. The ornament of the binding covers was emphasized by the modesty: the thin gold linear frames in various combinations (one double or wavy line) were pressed along the binding edges: the mirror of the front binding cover remained mostly clear; sometimes in its central part the emblem or monogram of the customer, a decorative image of military emblems of imperial Rome or ancient Greek ornamental motifs were placed. The focus was on the decoration of the spine or even binding those divided its surface into parts and were considered as components of the overall composition of the spine. This style in the decoration of book covers is called Etruscan.

At the beginning of the 18th century, French bookbinders from the Padeloup family started a new artistic system of cover decoration with small stamps: a drawn thread style (dentelle), which became known in Western Europe. Afterwards, one of the representatives of this family Antoine-Michel Padeloup, the court binder of the French king, began to make famous mosaic leather covers, ornamented with decorative gilding with the help of small stamps.

In the era of Rococo art style development, French artists and amateurs create various magnificent book labels. In the mid-eighteenth century, monogram-type ex libris appeared in the form of interlaced first letters of the name and surname of the collection owner. Sometimes the monograms surrounded by a frame made in the spirit of the requirements of Rococo aesthetics or framed by decorative elements of the architectural plan. In the second half of the 18th century, the plot and decorative book labels appeared. The ex libris depicted the interiors of the customer's libraries. In the 18th century, the book labels were begun to collect. 
In the first half of the 18th century, the revival of the traditionally high artistic and printing level of the Italian book began, which was connected with the active work of Venetian printers, artists and engravers. The reforms in the field of book printing, which took place during the 18th century in many European countries, were supported by the prominent Italian publisher Giambattista Bodoni (1740-1813). It was he with whom the glory of the revival of the artistic traditions in the book art of Italy was connected. In 1791, G. Bodoni founded his own printing house at the royal palace. In both the Royal and his printing press, he paid much attention to the font culture both in the Royal and his own printing house. ${ }^{38}$

At first, G. Bodoni used the font and type-sitting ornament created by French bookmaker Pierre Simon Fournier and later began to make his own fonts. Based on the achievements of well-known masters of the font William Caslon, John Baskerville, François-Ambroise Didot and his son Firmin, as well as under the influence of the aesthetic views of the founder of the classicism German Johann Winckelmann and his famous work History of Ancient Art (1764) G. Bodoni developed and cast wonderful Latin, French, Greek, Cyrillic and other fonts. G. Bodoni adhered to the clear contrast between thin and thick lines in the construction of letters. His fonts were distinguished by sublimity and solemnity, but at the same time, they were characterised by a certain classic static character. At the end of the century, G. Bodoni's style took shape finally: he refused completely from the use of the decorative ornaments so that readers could enjoy the "simple beauty of the letters." He stressed that printmaking should show "what success it can achieve without the help of decoration."The books of G. Bodoni - the "master of simplicity" - were distinguished by quality, harmony and monumentality. G. Bodoni emphasised that the book perfection is determined by the beauty of the letters. After all, the beauty of the font is the basis on which the art of typography is based, because letters are the main material of the book, and everything else exists in the book due to them. In the preface to The Manual of Typography $(1788,1818)$, G. Bodoni said: "The letter will be wonderful when it will be more clearly seen in its orderliness, diligence, good taste and elegance. But in order it looks clear on the page, it is necessary to place it in a wellaligned line, not dense but not free (the ratio of the height of the line

${ }^{38}$ Karakoz O. O. (2018) Istoriia knyhy [History of the book]. Kyiv: Lira-K, p. 315. 
should be taken into account); moreover, each line one should leave the same intervals between the individual words, as between squadrons in the regiment, at which it would be impossible to insert any of the labels included in the alphabet".

G. Bodoni paid much attention in order his publications were distinguished by a high printing culture. He required printers to identify "blind" and dirty letters during the printing process so that the prints on the two adjacent pages did not appear as if they were printed on different machines. A printer was often occurred that the artistic and printing tasks were more important to him than literary ones and that his well-designed editions did not meet either scientific or literary requirements. For example, F. Didot wrote in the Parisian Encyclopaedic Magazine: "As a literary man I condemn his publication, as a printer - I admire them." During his lifetime, G. Bodoni produced more than a thousand books, among them such masterpieces of printing art as the collection of works by T. Tasso (1789), Horace (1791), Virgil (1793) and others. In 1806 he published the remarkable edition Oratio Dominica (Our Father), in which this prayer was presented in 155 languages. ${ }^{39}$

In the middle of the 18th century, John Baskerville, the book printer, became famous in England. He founded a printing house with a typefoundry and a paper mill in Birmingham in 1750. J. Baskerville began to cast fonts on his projects. He perfected the composition of black printing ink and was also the first among European printers who used vellum paper. In 1757, J. Baskerville published his first edition, the works of Virgil, with the help of new antique fonts on vellum paper, and in 1758, John Milton's Paradise Lost. J. Baskerville created a new style of book design that was marked by typographic rigidity: the artist refused almost completely from the use of illustrations and ornamental decorations, giving preference to the font design of the book. J. Baskerville's antique fonts have much greater contrast between the basic and auxiliary strokes in the construction of letters, so scientists classify them as transitional fonts. Based on the graphics of these fonts at the end of the 18th century, the fonts of the classical direction were developed, which had a greater contrast than J. Baskerville's ones. His new style in book design was developed by such famous book masters as F. Didot in France and G. Bodoni in Italy. ${ }^{40}$

\footnotetext{
${ }^{39}$ Karakoz O. O. (2018) Istoriia knyhy [History of the book]. Kyiv: Lira-K, p. 316.

${ }^{40}$ Karakoz O. O. (2018) Istoriia knyhy [History of the book]. Kyiv: Lira-K, p. 317.
} 


\section{CONCLUSIONS}

During its development, the art of book of the 17th - 18th centuries embodied the main achievements, acquisitions, artistic traditions of the culture of the Early Modern Period. The dominance of the two great styles - Baroque and Classicism, was reflected in the design, decoration, and book font culture. In the 17th and 18th centuries, transformational changes occurred in the art of book design, which had an impact on the further development and elevation of book culture.

The European binding art is characterised by changes in the means of decoration; new styles as pointille, dentelle and Etruscan were formed. A new, more sophisticated book appeared in beautifully decorated covers with leather-bound bindings with painted or gilt edges.

The important changes occurred in the features of the illustrations, and there were enhanced ornamental and decorative motifs, for the creation of which the most striking and fascinating artistic means were used. The book design was determined by the extraordinary luxury. The artists and engravers showed perfect technical skills in the illustrative design.

The font culture reached a high artistic level, new types of fonts were created, the characteristic features of which were sublimity, solemnity, and classic static character.

The wonderful italics, new initials, numerous copper illustrations, cast ornaments from which small vignettes could be composed of, headpieces, and various framings in Rococo and Empire styles made the book a true masterpiece. The most prominent artists of that time participated in the illustrative framing.

The art book culture of the 17th-18th centuries had its peculiarity and uniqueness and was determined by special beauty. The art of book of that time reflected the process of revival of the world art traditions. The work of the famous artists, painters, printmakers, who used new ways of art expression, were of great importance for the development of the art of book of this period.

The book of the 18th century became more sophisticated and was determined by the harmonious combination of all elements, acquiring a high artistic level. The traditions were established by the book masters during the researched period became the main factor for the development of the book arts promotion.

\section{SUMMARY}

A book is a work of art that synthesises the artistic word and main achievements of the fine arts of a particular historical era. All decoration 
elements, both inside and outside the book, create a complete work of art. The aim of the article is to study the peculiarities of the formation of the art of book in the 17th - 18th centuries, taking into account the achievements of the world fine arts. The scientific novelty is determined by the fact that the research expands and deepens knowledge about the basic principles of the development of the art of book from the point of view of comprehensive objectivity. Conclusions. During its development, the art of book of the 17th -18 th centuries embodied the main achievements, acquisitions, artistic traditions of the culture of the Early Modern Time. The dominance of the two great styles - Baroque and Classicism, was reflected in the design, decoration, and book font culture. In the 17th and 18th centuries, transformational changes occurred in the art of book design, which had an impact on the further development and elevation of book culture. The art book culture of the 17th-18th centuries had its peculiarity and uniqueness and was determined by special beauty. The art of book of that time reflected the process of revival of the world art traditions. The work of the famous artists, painters, printmakers, who used new ways of art expression, were of great importance for the development of book arts promotion.

\section{REFERENCES}

1. Gerchuk Yu. Ya. (2000) Istoriya grafiki $i$ iskusstva knigi [The history of graphics and book art]. Moscow: Aspekt Press. (in Russian)

2. Halynska H. I. (2019) Rol khudozhnyka v knyzi dlia ditei [The role of the artist in a book for children]. Proceedings of the Khudozhnyk $i$ knyha (Ukraine, Kyiv, May 7, 2019) (eds. Chebykin A. V., Yakovliev M. I., Bitaiev V. A., Perevalskyi V. Ye., Fedoruk O. K., Berdynskykh S. O., Kharchenko P. V.), Kyiv: Natsionalna akademiia mystetstv Ukrainy, p. 7.

3. Hapon Yu. Ya. (1967) Mystetstvo oformlennia knyhy - vazhlyvyi faktor estetychnoho vykhovannia [The art of book designin is a very important factor of the aesthetic education]. Printing and Publishing, no. 3, pp. 147-153.

4. Hrypych S. (2011) Knyha yak osnova rozvytku dukhovnoi ta intelektualnoi kultury liudyny [The book as a basis for the development of spiritual and intellectual culture man]. Bulletin of the Book Chamber, no. 9, pp. $1-3$.

5. Karakoz O. O. (2018) Istoriia knyhy [History of the book]. Kyiv: Lira-K. (in Ukrainian)

6. Karakoz O. O. (2019) Tradytsiina knyha - fenomen suchasnoho sotsiokulturnoho prostoru [The traditional book is a phenomenon of 
modern socio-cultural space]. Library Science. Rekord Studies. Informology, no. 3, pp. 93-101.

7. Kharchenko P. V. (2019) Novyi etap rozvytku syntezu mystetstv v oformlenni suchasnykh drukovanykh vydan [A new stage in the development of synthesis of the arts in the design of modern printed editions]. Proceedings of the Khudozhnyk i knyha (Ukraine, Kyiv, May 7, 2019) (eds. Chebykin A. V., Yakovliev M. I., Bitaiev V. A., Perevalskyi V. Ye., Fedoruk O. K., Berdynskykh S. O., Kharchenko P. V.), Kyiv: Natsionalna akademiia mystetstv Ukrainy, pp. 31-32.

8. Lutsyshyna D. V. (2019) Pryntsypy synerhii u tvorenni ta prezentatsii art-knyhy khudozhnytseiu A. Komarovoiu [Principles of synergy in the creation and presentation of art books by artist A. Komarova]. Proceedings of the Khudozhnyk $i$ knyha (Ukraine, Kyiv, May 7, 2019) (eds. Chebykin A. V., Yakovliev M. I., Bitaiev V. A., Perevalskyi V. Ye., Fedoruk O. K., Berdynskykh S. O., Kharchenko P. V.), Kyiv: Natsionalna akademiia mystetstv Ukrainy, pp. 13-14.

9. Markova V. A. (2009) Mystetstvo knyhy: komunikatyvnyi aspekt [The art of the book: the communicative aspect]. Visnyk Kharkivskoi derzhavnoi akademii kultury, iss. 28, pp. 100-106.

10. Mitchenko V. S. (2019) Pro maibutnie paperovoi knyhy [About the future of the paper book]. Proceedings of the Khudozhnyk $i$ knyha (Ukraine, Kyiv, May 7, 2019) (eds. Chebykin A. V., Yakovliev M. I., Bitaiev V. A., Perevalskyi V. Ye., Fedoruk O. K., Berdynskykh S. O., Kharchenko P. V.), Kyiv: Natsionalna akademiia mystetstv Ukrainy, pp. $15-16$.

11. Ovchinnikov V. (2005) Istoriia knyhy: evoliutsiia knyzhkovoi struktury [History of the book: evolution of book structure]. Lviv: Svit. (in Ukrainian)

12. Yeroshkina O. O. (2017) Epokha baroko [The Baroque Era]. Kharkiv: O. M. Beketov Kharkiv National University of Urban Economics. (in Ukrainian)

\section{Information about the author: Karakoz Olena, orcid.org/0000-0002-7772-1530} $\mathrm{PhD}$ in Historical Sciences, Associate Professor Kyiv National University of Culture and Arts 36, Yevhen Konovalets Str., Kyiv, 01133, Ukraine 
DOI https://doi.org/10.36059/978-966-397-197-1/173-190

\section{KYIV THEATRE AND ENTERTAINMENT SPACES IN THE PERIOD FROM THE ELEVENTH TO EARLY TWENTIETH CENTURIES}

\section{Iudova-Romanova Kateryna}

\section{INTRODUCTION}

Kyiv was the centre of cultural and artistic life, in particular, of theatrical life under Kyivan Rus, as the frescoes of the Cathedral of St. Sophia, built in the reign of Yaroslav the Wise (the first half of the 11th century), are preserved to this day, had depicted performances of professional entertaining fellows - skomorokhs. ${ }^{1}$ Kyiv, as well as other medieval cities, attracted these yesterday's wisecrackers and dancers. However, the first theatrical forms - elements of actor's transformations, costume, stage make-up, mimic dance, vocal performance, music - are associated with ritual games of a mimic nature and arose at an early stage in the development of the social relations and persisted for centuries.

With D. Antonovych's research, the first documented date of the theatre onstage performance in the Ukrainian language was defined. It was August 29, 1619: "On this day two Ukrainian interludes were performed at the fair in the town of Kamianka Strumylova, near Lviv". 2 A small wooden theatre behind the Jesuit Gate in Lviv (in the area of the modern square of I. Pidkova, closer to the Poltva river) is considered by the scientists to be the first permanent entertainment public institution in the territory of modern Ukraine. This house, adapted to theatrical needs, was a ranked theatre with a distinct parting into circles with boxes and the stalls with a gallery. The theatre had a short-lived existence, and it

1 Teatry Kieva [Kyiv Theaters] (1985). Kudrytskyi A. V. (ed.) Kyiv: Entsiklopedycheskyi spravochnik. Kyiv: Glavnaia redaktsyia Ukrainskoi sovetskoi entsiklopedii, pp. 604-606.

2 Antonovych D. (1925) Trysta rokiv ukrainskoho teatru. 1619-1919 [Three hundred years of Ukrainian theater. 1619-1919]. Prague: Ukrainskyi hromadskyi vydavnychyi fond, citation p. 7 . 
was dismantled in $1783 .{ }^{3}$ The religious building of the Gothic Church of the Holy Cross at the Franciscan monastery was transformed into the first in Lviv stone permanent theatre (1787-1872). There were 36 boxes in two circles, 114 folding chairs and 200 seats, rather simply benches, in the stalls and standing places in the gallery. ${ }^{4}$ The theatre remained in the church building until the middle of the 19th century.

\section{The Birth of Theatrical Traditions in Kyiv}

Kyiv, the capital of modern Ukraine, developing as a political and administrative centre, has remained a cultural centre of the Slavic peoples throughout the centuries. Since ancient times the spiritual life of the Old City of Kyiv has been connected with the theatre art. The word "skomorokh" was first mentioned in the 1068Laurentian Chronicle. It was used to call those who entertained the people "entertaining fellows" - who not only sang and danced, but also showed trained animals, put on "faces" and "masks", performed comic scenes. The frescoes of the Cathedral of St. Sophia, which are attributed by the scientists to 1037, illustrate the activities of skomorokhs in the territory of Kyivan Rus. The performance in the prince's palace, judging by the fresco, began with a prologue: one skomorokh, opening the curtain, addresses to the audience. In the centre, there is dancing accompanied by two pipe players and two musicians with string instruments. One of them is playing a flute and dancing and the second one is hitting the cymbals. On the right, there is a scene with acrobats: one of them is holding the pole, and the other one is climbing it up. On the left there are fighters are waiting for their exit.

After the dark ages of the Tartar-Mongol ruin and the LithuanianPolish domination, the depressed spiritual life of the city began to develop in Podil - in the part of Kyiv, which suffered the least and managed to rebuild as soon as possible thanks to its advantageous location near the Dnieper trade routes. This process intensified in times of national consciousness revival particularly actively, when there was the beginning of the liberation struggles of our people. Formation of the Kyiv Brotherhood in 1615 with the support of the Cossack army headed

3 Proskuriakov V. I. (2002) Pryntsypy rozvytku arkhitekturnoi typolohii ukrainskoho teatru [Principles of development of the architectural typology of the Ukrainian theater] (PhD Thesis), Lviv: National University "Lviv Polytechnic", 147.

${ }^{4}$ At the same place, pp. $152-153$. 
by Hetman Petro Sahaidachny once again made the city the centre of Ukrainian spiritual life. Kyiv-Mohyla Collegium was set up on this powerful basis. It was the first higher educational institution in Ukraine and Eastern Europe, which in 1701, having received the status of the academy, became the first centre of Kyiv theatre life. ${ }^{5}$ The Collegium was initiated in 1632 by the association of Kyiv Brotherhood and Lavra Schools, which had the tradition of stage performances by the students. In its new building, built with the assistance of Hetman Ivan Mazepa in Podil in 1703-1704 (architect - I. Shchyrskyi, rebuilt in 1735 by architect J.-G. Schaedel ${ }^{6}$ ) the students and the academics of the Academy Simeon Polotskyi, Dmytro Tuptalo, Theophan Prokopovych performed their dramatic works. From the academic building on Kontraktova Square, the art of the theatre, which existed at that time in the form of school drama, with the efforts of students began to go out to Podil during the fairs. But this centre of theatrical culture exported stage art not only to our city, but also to the great Russian Empire, under whose control Ukraine was at that time.

In particular, Simeon Polotskyi, who worked at the Moscow Zaikonospaska school in the 1660s, where the Moscow Theological Academy was formed later basing on his ideas, initiated the production and performance of his dramatic works in Moscow. And Dmytro Tuptalo, who became metropolitan Dymytriy Rostovskyi in Russia, supported first city theatre troupes in Yaroslavl at the beginning of the 18th century. Among other things, it was his play Repenting Sinner that was performed at the court of Elizabeth, empress of Russia, in the early 1750 s and among the first performances of the famous Yaroslavl theatre troupe under the management of Fedor Volkov, it was the one from which the Russian state theatre originates. ${ }^{7}$

But the times changed and the outdated aesthetic principles of school drama and the archaic organizational principles of its stage performance began to restrain the development of the theatre. The thing was that the

5 Teatry Kieva [Kyiv Theatres] (1985). Kudrytskyi A.V. (ed.) Kyiv: Entsiklopedycheskyi spravochnik. Kyiv: Glavnaia redaktsyia Ukrainskoi sovetskoi entsiklopedii, pp. 604-606.

6 Sherotskyi K. V. (1994) Kyiv [Kyiv]: putivnyk: repryntne vidtvorennia vydannia 1917 roku. Kyiv: Kobza, 166-167.

7 Vsevolodskyi-Hernhross V. N. (1977) Istoria russkogo dramatycheskoho teatra. Vol. 1: Ot istokov do kontsa XVIII veka [History of the Russian Drama Theatre. Vol. 1: From the origin to the end of the 18th century]. Moscow: Iskusstvo, citation p. 80. 
participants of the school's theatre process did not aim to become professional actors, and even more - they were afraid of this, because in tsarist Russia at that time the professional stage career automatically blocked up the way to the students from the aristocratic strata of society to use their status privileges. And such students were the overwhelming majority in the Academy. In addition, in 1817, the tsarist government closed the Academy, which irritated the Moscow authorities with their Ukrainophilia sentiments. The Mazepa building of the Academy did not survive, but the spirit of the theatre living in this building remained within the ancient Podil.

\section{Temporary Theatrical and Entertainment Premises of Kyiv}

The "vaccination" with the theatre took place, and later theatrical traditions were found in other parts of the city. In particular, in 1789-90, in one of the wings of the Mariinsky Palace in Pechersk, public theatrical performances were held. ${ }^{8}$ The city authorities were sympathetic to create theatres, seeing them as not only an attribute of the prestige of the city as a cultural centre but also a commercial benefit from the taxpayer.

In 1811 a huge fire occurred in Podil, after which almost all the Lower Town, as Podil was also called, had to be redesigned and rebuilt again. The well-known Kyiv architect W. Hastie supervised these works. According to his project, developed in co-authorship with another famous Kyiv architect A. Melenskyi, a grand building in the style of classicism - the Contracts House - was erected on the Kontraktova square, not far from the Academy, when it was closed in 1817.

The main purpose of this building was to serve the famous contract fairs, which at the end of the 18th century were transferred to Kyiv from Dubno. In this regard, on the first floor, there were offices of banks, premises for negotiations and agreements, as well as restaurants. And on the second floor, there was a large theatre and concert hall, as the fairs were accompanied by performances by well-known actors and theatrical troupes, as well as balls and masquerades. It is precisely known that in the hall of the Contracts House, the residents of Kyiv saw performances by the Italian opera, the singer A. Catalani and the musician's brothers

${ }^{8}$ Maryynskyi dvorets [Mariinsky Palace] (1985). Kudrytskyi A. V. (ed.) Kyiv: Entsiklopedycheskyi spravochnik. Kyiv: Glavnaia redaktsyia Ukrainskoi sovetskoi entsiklopedii, 376-377. 
G. and Yu. Wieniawski. And a memorial plaque on the house says about the tours of the prominent Hungarian composer and pianist Franz Liszt.

The turn of the 19th - 20th centuries is a very important stage in the life of Kyiv. It was during this period that the city was rapidly developing. So, if in 1806 the city had 27.2 thousand population, in 1850 - 50 thousand, in 1897 - 247.7 thousand, then in 1913 the population of Kyiv was 626 thousand people. ${ }^{9}$ That is, for one hundred years the number of inhabitants has grown by 23 times. This was due to the rapid growth of industry, transport, construction and service sectors. Kyiv of the first half of the nineteenth century was already the thirdlargest city in the Russian Empire. In general, in the late XVIII - early XIX centuries the first city theatres appeared on the territory of Ukraine. The oldest of them was built in Kharkiv in 1789. In 1804-1806 the wooden building of the first Municipal Theater in Kyiv was built and from 1806 mobile bondmen troupes performed there.

It is known that Kyiv as a European-type city consisted of four main parts - the Old City (the ancient city of Yaroslav), Podil, Pechersk, as well as the suburbs: Ploska Sloboda, Lukianivka, Kurenivka and others. ${ }^{11}$ Each of these administrative units, with the exception of the suburbs, played a leading role in the city's social and cultural life at various historical times. And insofar as some of the parts occupied a dominant position, there appeared centres of theatrical life that performed their communicative functions.

The increase in the population, which occurred primarily because of the migration of rural residents and residents of other cities, led to the typical processes for urban culture at that time. This social and cultural phenomenon is connected with the solution of the problem of creating a unique association of people - the population of a certain city, in this case - Kyiv. Of course, under the conditions of the social and political imperial system of tsarist Russia, it was impossible to create a

9 Rybakov M. O. (1997) Nevidomi ta malovidomi storinky istorii Kyieva [Unknown and little-known pages of the history of Kiev]. Kyiv: Kyi, 183, 191, 194.

${ }^{10}$ Bernadska H. (1994) Kyivskyi miskyi teatr (do istorii orhanizatsiinykh form) [Kyiv City Theater (to the history of organizational forms)]. Aktualni problemy orhanizatsii teatralnoi spravy [Actual problems of theatrical affairs organization]: tematychnyi zbirnyk naukovykh prats, Kyiv: Kompas.

${ }^{11}$ Kudrytskyi A. K. (ed.) (1982) Kyiv: Istorychnyi ohliad: (Karty, iliustratsii, dokumenty) [Kyiv: Historical overview: (Maps, illustrations, documents)]. Kyiv: Holovna redaktsiia Ukrainskoi radianskoi entsyklopedii, pp. 69-70. 
homogeneous urban population - it was stratified by certain urban social groups. In order to solve this problem, it was necessary to invent certain communicative means that would allow various members of the society with their far from the same social, cultural and educational level to feel as the united city community. And such a communicative lever in the city appeared - it was the theatre.

Here's how this social and cultural mission of scenic art is determined by the researcher of the social psychology of arts, Nikolai Khrenov. Studying the peculiarities of communicative opportunities of cities at the turn of the XIX-XX centuries and spectacular forms of communication, he said: "In the development of urban culture, one can trace the stages when the city could not use the means of communication, capable of resolving many of its communicative contradictions immediately and fundamentally. Initially, the city tried to regulate the emotional life of the new community of people by traditional means. It resorted to spectacles, in particular to the theatre. The theatre [...] is the immediate successor of spectacle and play forms [...], only adapted to the conditions of the city". The author further states, that under the conditions of domination of illiterate and ignorant urban population, theatrical art had communicative advantages over book-printing. As a result, "the theatre flourished at the initial stages of the urban culture formation. It seemed to replace other types of arts". ${ }^{12}$

\section{Stationary Theater and Entertainment Places - Centers of Theatrical Culture of Kyiv}

Nevertheless, the need for a special theatre for the city, whose theatrical life was developing quite rapidly, was felt more and more acutely. The supporters of Melpomene no longer arranged the performances that were given in random non-adapted premises, for example, on the Podol in the house of the former prison. It is precisely to this period of Kyiv's theatrical life that I.K. Karpenko-Kary wrote the words reported by P.K. Saksahanskyi in March 1897 at the First AllRussian Congress of Stage Actors in Moscow. It went about the situation and prospects of the theatre development in general on the territory of Ukraine and Russia and theatre premises in particular: "There are no

12 Khrenov N. A. (1981) Sotcialno-psikhologicheskie aspekty vzaimodeistviia iskusstva i publiki [Social and psychological aspects of the interaction of art and the public]. Moscow: Nauka, citation pp. 198-199. 
theatres in the province and the performances are given in bad, cold, sheds with drafts and without amenities for the public, which are more suitable for stables than for the theatre". ${ }^{13}$

And finally, in 1804, a decision was made to build the first special theatrical premise in Kyiv for 470 seats under the project of A. Melensky, already mentioned by us. The place was chosen at the beginning of the Khreshchata valley, on the square, which then was called Kinna (now European), in the place where the palace of arts "Ukrainian House" is now located. It was chosen not accidentally - it was there that the main paths that united all the scattered areas of the city converged. When at the beginning of XIX century the process of their administrative unions was completed, this "umbilical cord" of the new European city needed a certain spiritual centre that would unite the inhabitants of the Old City, Podil, Pechersk and the suburbs. And the first in Kyiv special theatre premise played the role of this centre, thanks to which the old Kinna Square became known as the Theater Square, while the new main street of the city - Khreschatyk for some time was called Theater street.

After this wooden premise had seen long service and was dismantled in 1851, this place did not lose the status of the city's theatrical life centre. In 1882, in front of the place where the first theatre was located, and then the European Hotel (which gave the new name to the square), the famous Kyiv architect V. Nikolaiev built the house of the Merchants' Assembly at the expense of Kyiv merchant M. Dehtiariov. Its hall was characterized by extremely good acoustics, and there were constant concerts and plays, balls and masquerades. No wonder this building today belongs to the National Philharmonic of Ukraine and is considered to be the best concert hall of the country.

Behind the House of the Merchants' Assembly in the summer garden, which carried the same name - Merchant, the premises of the summer theatre were built in 1890, which became popular with the public belonging to different social classes due to the fact that there were mostly Ukrainian theatre troupes of M. Kropyvnytskyi, P. Saksahanskyi, "The Society of Ukrainian Actors with the Participation of Maria Zankovetska and Panas Saksahanskyi under the command of Ivan

13 Karpenko-Karyi I. K. (Tobilevych, I. K.) (1985) Zapyska do z'izdu stsenichnykh diiachiv [A note to the congress of stage figures]. Tvory. Vol. 3: Dramatychni tvory. Statti. Lysty [Works. Vol. 3: Dramatic works. Articles. Letters]. Kyiv: Dnipro, citation p. 279. 
Marianenko" and others. In the same building in 1917-1919, the first Ukrainian stationary theatre of Mykola Sadovskyi held its last seasons in Kyiv.

A little far ahead of the European square in the depths of the park area, to the left of Oleksandrivska street (now M. Hrushevskyi street), which led to Pechersk, since 1863 there was a park entertainment centre "Chateau de Fler" ("Castle of flowers"). This spectacle building, which greeted Kyivers with beautifully decorated entrance from Oleksandrivska street, united in itself a cafe, a restaurant and two summer theatre stages. The latter were sometimes taken by the troupes of the Russian Drama Society, and more often by some groups of actors who "performed light theatrical genres" - farce, variety, miniatures, operettas.

By the way, the second city theatre, especially for the operetta, was built in 1912. It was located next to "Chateau de Fleur", on the corner of Oleksandrivska and Parkova streets (Petrivska Alley). Unfortunately, this building did not survive - in its place today there is the central entrance to the Dynamo Stadium. The same fate happened to all the other (except for the Merchant's House) premises of this centre of the theatrical and cultural life of our city, that perished in the whirlwind of dramatic historical events that the 20th century was so rich in.

By the end of the 1840s, the old building of the first Kyiv City Theatre became unfit for work, and there was a need for the construction of a new theatre. Kyiv authorities faced the question of where to build a new theatre. After a long search, it was decided that the place on the corner of Volodymyrska and Kadetska streets (now B. Khmelnytskyi Boulevard) will become the new theatrical centre. And it was not by chance since it was at that time that the Old City and its adjoining territories began to revive. A new cultural centre of Kyiv was formed in this neighbourhood, which centred around the new building of Saint Volodymyr University, built by architects Vincent and Alexander Beretti in 1837, as well as the buildings of the 2nd and 1st Kyiv Gymnasiums, built respectively in 1850 and 1852 according to O. Beretti`s projects on both sides of Volodymyrska Street on Bibikovskyi Boulevard (now T. Shevchenko Boulevard).

That is why, the third element of spiritual culture - the temple of art had to continue this street of science and education. And it was built in 1856 a quarter away from these houses, almost under the walls of the Old City. Now there is the National Opera of Ukraine. The new theatre was called the Second City Stone Theatre. The theatre opened on October 2, 1856. Academician of Architecture I.V. Shtrom was the 
author of the project for the new theatre building. The new stone theatre, for which the treasury spent 130,000 rubles, turned out to be very successful in terms of theatrical architecture and stage technique. He had a well-developed Italian stage box and a beautifully decorated auditorium for 849 seats, which, moreover, had devices for transforming into a ballroom. Here, along with dramatic performances, opera and ballet performances were given.

But this remarkable building gave Kyivans pleasure of communicating with the art of the scene only for 40 years - in 1896 the theatre was almost completely burnt down because of a not-put out a candle in an actor's dressing room. And again there was the question about the construction of the main theatre for the city. There was no longer a need to look for a place for it, as the Kyivans firmly associated corner of Volodymyrska and Fundukleivska streets (former Kadetska, and now B. Khmelnytskyi street) with the city's most important theatrical centre.

And this is no accident because modern studies on social psychology have shown that in the mass consciousness of people - the potential audience - among the many factors that determine the choice of viewing the performance of this or that theatre, the place of its location is very important. That is, in the process of aesthetic preference formation in the human psyche there is a subconscious association with a certain theatrical space. The builders of the new premises of the first Kyiv City Theatre could not then know about these much later scientific findings, but the path of empirical experience led them to make the right decision.

The construction of the new theatre was preceded by an international competition under the auspices of the Imperial Society of Architecture, in which the project of the famous Russian designer of theatre premises, Professor V. Shreter won. By that time he had already gained the fame of the architect of the theatres in Nizhny Novgorod, Tiflis, Irkutsk, Rybinsk and the head of the reconstruction of the Imperial Maryisk (St. Petersburg) and the Bolshoi (Moscow) theatres. Therefore, the choice of Kyivers was not accidental and the project was implemented in three years under the guidance of the famous Kyiv architect V. Nikolaiev. The Kyiv Opera House became a remarkable ensemble of the facade of a neo-Renaissance structure with a successful functional purpose: the architect took care of the convenience of both actors and spectators, creating exquisite interiors that combine the classical style and the so-called "Vienna Modern", which perfectly fitted in the architecture of all major European cities. 
The three-circle hall could seat 1683 spectators at the same time. After two reconstructions (1935 and 1988), the theatre now has just over 1300 seats due to the orchestra hole expansion and removal of inconvenient seats. On September 16 (29), 1901, the solemn performance of cantata "Kyiv" by the Swedish composer Wilhelm Harteveld, written especially for this event, and the play "A Life for the Tsar" by M. Hlinka made the grand opening of the new building of the theatre. Taras Shevchenko National Opera of Ukraine works there now ${ }^{14}$.

Incidentally, the appearance of another theatrical space, which completed the formation of this centre of the city's theatrical life is connected with the name of the already mentioned chief architect of Kyiv V. Nikolaiev. We mean the so-called "Berhonier Theatre" in Fundukleivska street two blocks below the first city theatre. The history of this theatre is quite interesting.

In 1868, Frenchman O. Berhonier bought a manor on the corner of Fundukleivska and Novo-Lyzavetynska streets (now Pushkinska street) to build a circus. In 1875 the circus theatre "Alcazar", created under the project of V. Nikolaiev between the houses of not spectacular purpose, was opened at this place. But in Kyiv at that time, similar to present days, there were not enough special theatre premises, so in 1878 the circus was rebuilt and turned into a theatre. The interior space between the buildings became a theatre, like a circled theatre in Spain of the Renaissance. The yard was covered with a roof, the stalls and the backstage were formed below, and the boxes and the balconies were made from the interior windows and floors of the houses. That is why, for "Berhonier Theatre" (it was called so until 1919), for a long time, until the later reconstruction, it was not possible to use the premises of the nearby houses where the hotel, restaurant and shops were located.

This stage, where Lesia Ukrainka National Academic Theatre of Russian Drama currently operates, saw many prominent masters. In particular, there were Ukrainian troupes of coryphaeus, as evidenced by the memorial plaque, "Molodyi Theatre" and "Berezil" by Les Kurbas, the Society of Dramatic Actors of M. Solovtsov.

With the latter - an outstanding actor, director and organizer of a theatrical affair, creation of another centre of theatrical culture in Kyiv is

14 Turkevych V. Pro teatr [About the theatre] Natsionalna Opera Ukrainy [Official site]. Retrieved from: https://www.opera.com.ua/about/istoriya-teatru (accessed 4 May 2019). 
connected. It appeared in the so-called "Merinhivskyi square" - the place of the last major redevelopment of the central part of Kyiv, which gave it a completed territorial and architectural appearance. This land plot between Khreshchatyk, Instytutska, Bankivska and Lutheranska streets belonged to Professor of Kyiv University F. Mering, and after his death, it was sold to Joint-Stock Housebuilding Company for 800 thousand rubles, that was specially formed for the redevelopment of the block.

The Company paved Nikolaievska (now Architect Horodetskyi), Olhinska, Nova (now Stanislavski) and Merinhivska (now M. Zankovetska) streets. The redevelopment of these streets was planned by a group of Kyiv architects headed by H. Schleifer. Already by the autumn of 1897, the Merinhovskyi Square was filled with refined houses in a single architectural style - the "Vienna Modern".

M. Solovtsov, who found Berhonier Theatre premises unsuitable, with the support of the city authorities, initiated for the House-building Company the need to build a new theatre at the end of Nikolaievska Street. Its project was developed by Ye. Bradtman and G. Schleifer, and in October 1898, M. Solovtsov`s troupe began the next season in the new building, which after the death of this outstanding entrepreneur was called Solovtsov Theatre. Incidentally, this building, like most of the others in the Merinhovskyi square, did not belong to the city. The famous Kyiv businessman Lev Brodsky, who leased it to Solovtsov Theatre was its owner. After the revolution the Russian drama theatre, created on the basis of Solovtsov's troupe, worked in this building, then artistic association "Berezil" under the direction of Les Kurbas played its performances there, and since 1926 it has been occupied by I. Franko National Ukrainian Drama Theatre.

Solovtsov Theatre became a theatrical and spectacular centre, which arose in this fashionable district of Kyiv. In 1899, on Merinhovska street in conjunction with a respectable club, architect G. Schleifer built the socalled "New Theatre" or " Medvedev Theatre", called so by the Kyivans in honour of its master, the outstanding opera singer and teacher M. Medvedev.

After the fire in 1910, the theatre was rebuilt and instead of Medvedev's troupes, there were operetta groups and national troupes. In 1918, the State Drama Theatre was founded in this building, the oldest of the existing Ukrainian theatres (now T. Shevchenko Dnipropetrovsk Ukrainian Music and Drama Theatre). In 1919, there were attempts to create the first Ukrainian state opera theatre - Musical drama on this basis. Later there were different troupes playing there, and from 
1933 until the Great Patriotic War (1941-1945) there was a drama theatre of Kyiv Special Military District. Unfortunately, the flames of war did not leave us this theatre premise with a well-equipped stage.

Nearer to the head of Mykolaivska Street in 1903 under the G. Schleifer's design another spectacular building was built, which immediately became unique. It is about the premises of the only one at that time, not only in the Russian Empire but even in Europe, a stone two-storey circus that had about 2000 seats. He was called "Hyppo Palace" ("Kinnyi palace"), or Krutikov Circus after the name of its owner. This premise could be transformed and it had quite good acoustics that is not typical for circuses with their dome-shaped ceiling. It was used not only for circus performances but also for other entertainment activities. ${ }^{15}$ F. Chaliapin, L. Sobinov, M. LytvynenkoVolhemuth, M. Battisti sang there, O. Kuprin and V. Maiakovskyi with the team of futurists organized literary evenings. And in 1912, Kyivans saw on this stage the legendary performance of the prominent German director M. Reinhardt "King Oedipus". Unfortunately, this building also was ruined during the Second World War and cinema complex "Ukraine" was there in its place for a long time.

Opposite Krutikov Circus simultaneously with it the premises of "Farce on Nikolaievska" theatre were built. This was a typical premise of a variety show for Kyiv at the time. There were many similar ones on Khreshchatyk, Fundukleivska, Prorizna and other central streets of the city. The researchers calculated about 50 variety shows in Kyiv at this time $^{16}$, which united all previously scattered centres of the city's theatre life. In the thirties of the 20th century, the second in Ukraine theatre for children - Kyiv Youth Theatre - worked in the premises of the former "Farce on Nikolaievska" theatre. But again, with sadness, we would like to emphasize that this building also suffered the fate of other spectacle premises of the Merinhovskyi square - at the place where it was located, there is a mini-park now.

${ }^{15}$ Natsionalnyi tsyrk Ukrainy [National circus of Ukraine] (2012) Kyiv Velychne misto. Retrieved from: http://kiev-pravda.kiev.ua/2012/05/nacionalnij-cirk-ukraini/ (accessed 4 May 2019).

16 Katasonova T. V. (1995) Funktsionuvannia teatriv malykh form Kyieva u 1917-1918 rr. (sotsiokulturnyi aspekt) [Functioning of the variety shows of Kyiv in 1917-1918 (socio-cultural aspect)]. (Candidate of science), Kyiv: Kyiv University of Culture. 


\section{Theatre Centers at the Edges of Kyiv}

Recently the theatres of the suburbs became the theatrical centres of our city. At the turn of the 19th-20th centuries the district that grew along the former Vasylkivskyi road (Velyka Vasylkivska street) on the place of the so-called "Nove Stroiennia", which stretched to the Lybid and Demiivka River formed the suburbs of Kyiv. Also, the suburbs of Kyiv were formed by the areas that were built along the streets, which diverged from Lviv square - Lukianivka and Kurenivka, and from Halitskaya Square (now Victory Square) - Shuliavka and Sviatoshyn districts.

Mainly people from villages who moved to Kyiv to find work at new industrial enterprises of the city lived in these areas. That is why there was a very acute problem of providing uniting communicative means to these groups of the population who lost their social orientation as a result of a sharp change in the usual way of life. And this function was again taken over by the theatre.

At the turn of the 19th-20th centuries in Russia, the movement of socalled people's theatres received widespread development, various civic organizations took care of their arrangement, among which there were two distinct ones - the Society for Public Education Promotion and the National Sobriety Curatorship. The latter, in particular, was quite welloff in the financial perspective, since, in addition to charitable contributions, it received subsidies, which the state provided after the introduction of the state wine monopoly in Russia. This activity of the then Minister of Finance, Count S. Witte, who, incidentally, founded the Curatorship, a few years after its introduction became one of the main profitable articles of the budget of the empire. And in the arrangement of people's theatres, then, the government saw a utilitarian means for distracting the masses from drunkenness and revolutionary ideas. Here's how this problem is defined by the modern Russian researcher H. Haichenko: "For a big city, the need for a people's theatre became an axiom of pure water". ${ }^{17}$

There were two main types of people's theatres - professional ones, which set the goal of cultural service of the masses and amateur ones,

17 Khaichenko H. A. (1975) Russkiy narodnyi teatr kontsa XIX - nachala XX veka. [Russian people`s theater of the late XIX - early XX century]. Moscow: Nauka, citation p. 100. 
where the representatives of these masses performed themselves. In Kyiv, there were both the first and second ones.

The Troitsky People's House of the Society for Public Education Promotion belonged to the first type. It was built in 1903 on Velyka Vasylkivska street. The Troitsky People's House didn't have its own troupe at first, and the Society rented out this cosy theatre to entrepreneurs, provided that they would work for the inhabitants of Kyiv suburbs. Here is how M. Sadovskyi, who founded in Troitskyi People's House the first in Ukraine stationary Ukrainian Theatre in 1907: "The prices in the theatre were so scanty that it was impossible for anyone to compete with them. [...] Of course, I did it in order to attract the poorest public to the theatre. [...] So with every season I brought up the audience that I needed and that before that time was absolutely indifferent to the theatre". ${ }^{18}$ Sadovskyi can be understood as Kyiv theatre audience at that time wanted to visit the theatre in an unusual place - in the suburbs and in addition a Ukrainian-language theatre. Sadovskyi's great zeal was that he was able to form a new centre of theatrical culture in Kyiv and for the first time it was a Ukrainian-language theatre.

Lukianivskyi People's House of the National Sobriety Curatorship belonged to the second type. It was built at the corner of Lukianivska Square and Dehtiarivska Street in 1902 under the project of architect M. Artynov. The building in the pseudo-Russian style had a spectator hall for 600 seats. Unlike the Troitsky People's House, Lukianivskyi People's House did not have a permanent theatrical troupe, and there were amateur performances and concerts by the people of Lukianivka on its stage. Sometimes there were performances by the students of M. Lysenko music and drama school, actors of the "Molodyi Theater" and other professional performers. There was a free library, a dining room, a book store, an evening school for adults, a legal aid agency and a kind of a hostel in Lukianivskyi People's House. In Soviet times, the Club of Tram Workers was located here, and now in its walls, there are performances by the young cohort of opera performers and directors of the Kyiv Small Opera. ${ }^{19}$

18 Sadovskyi, M. K. (1956). Moi teatralni zghadky. 1881-1917 [My theatrical memories. 1881-1917]. Kyiv: Obrazotvorche mystetstvo i literatura, citation p. 171.

19 Pietushkova M. (2019) Kyivska mala opera: vid budynku tverezosti do miskoho art-prostoru [Kyiv short opera: from the house of sobriety to the urban art space]. InfoLife. Retrieved from: https://life.informator.news/kyivs-ka-mala-operavid-budynku-tverezosti-do-mis-koho-art-prostoru/ (accessed 4 May 2019). 
However, even earlier than Lukianivskyi People's House in Kyiv there was built another building of the same type. It was called People's Audience and belonged to the Society for Public Education Promotion. It was built in 1895 on the Bulvarno-Kudriavska street under the design of the architect M. Beleliubskyi. The Public Literary and Artistic Society, widely known in Kyiv, arranged performances of art workers in this building, which did not have a permanent troupe either. It was created in the same year in 1895 by well-known figures of culture and art O. Andriievskyi, V. Naumenko, M. Tutkovskyi, M. Solovtsov, M. Medvedev, T. Chuzhbynin, M. Roshchyn-Insarov, V. Nikolaiev and others. Later, Lesia Ukrainka, M. Lysenko, M. Starytskyi, M. Sadovskyi, P. Saksahanskyi, M. Zankovetska joined the society. As we can see, among the founders and members of the society there were enough mentioned in our work respectable people, who did a lot for the development of theatre and art centres of Kyiv.

\section{CONCLUSIONS}

Summing up, it should be emphasized that we did not aim to reveal insights into the history of all theatres in Kyiv in this article, there were much more than we have listed. For example, we did not talk about the district of the city as Pechersk. Indeed, Pechersk did not have such a defined centre of theatre life as the aforementioned. Therefore, the reason was the fact that this district of Kyiv with the holy shrine of the Orthodox world Kyiv-Pechersk Lavra has been the centre of spiritual and religious life since ancient times. And a negative attitude of the church to the theatre is well known. However, even in Pechersk, there were separate theatre buildings. In particular, the first in Kyiv summer theatre, built in the Tsarskyi garden over the Dnieper in 1834, or the building of General Bilohorskyi that was used as a found space for theatrical performances.

Much more can be said about the theatre premises in Khreshchatyk, among which was the so-called O. Kramskyi Malyi Theatre. Park theatres "Hermitage" on Trukhaniv Island, "Venice" in Nikolska Slobidka, "Eldorado" on Brest-Litovsk Highway. However, this is also the subject of a separate study. The research concerns a highly topical issue, since Kyiv, where no special theatre spaces have been built for the last 100 years, keeps growing and developing.

Theatrical traditions in Kyiv were initiated by the activity of skomorokhs during the Kyivan Rus period, as evidenced by the chronicles and architectural monuments of the 11th-century culture. 
Subsequently, in the 17th-18th centuries, the city's theatre culture continued to evolve through the activities of theological seminaries, in particular, the Kyiv-Mohyla Academy, in the form of school drama. At the turn of the 19th-20th centuries, the rapid development of Kyiv and the need to establish sustainable and productive social communications in the city led to the construction of specialized premises for the creative and organizational activity of theatrical and spectacular private theatrical enterprises. In 1804, construction of the first special theatre premises in Kyiv in Kinna square (now European square) united the inhabitants of different districts: the Old City, Podil, Pechersk and the suburbs. Subsequently, other establishments of cultural and leisure destination began to appear nearby. In 1856, construction of the Second City Stone Theatre on the corner of Volodymyrska and Kadetska streets (now B. Khmelnytskyi Boulevard) laid the foundation for the formation of a new theatrical centre in Kyiv- a circus theatre "Alcazar" was opened here in 1875. At the turn of the 19th-20th centuries a new city theatre centre was formed around new theatres and Krutikov circus in the new respectable "Merinhivskyi Quarter". There were also several other spaces in the suburbs of the city, in which theatre life seethed, in particular, the Trotsky People's House and Lukianivskyi People's House. Given the location in the Pechersk hills of Kyiv Lavra - the Orthodox centre of spiritual and religious life - theatre buildings were constructed extremely selectively here.

\section{SUMMARY}

The purpose of the article is to determine the genesis and basic stages of the theatre and art life centres formation of Kyiv as a social and cultural communicative system in the period from the first half of the 11 th to the early 20th century and the role of theatre and entertainment spaces of the city therein. The scientific novelty is determined by the fact that for the first time in the field of art studies, using the activity of theatrical and entertainment premises of Kyiv of the defined period as an example, the centres of theatrical life as social and cultural communicators have been observed and structured. Conclusions. Kyiv theatrical traditions originated in Kyivan Rus. In the 17th-18th centuries, the city's theatrical culture developed in the form of school drama based on the activities of theological seminaries, in particular, the Kyiv-Mohyla Academy. At the turn of the 19th-20th centuries, the rapid development of Kyiv and the need to establish sustainable and productive inter-social communications in the city let to the construction of specialized theatre 
and entertainment spaces, where four main theatrical centres were gradually formed: near Horse's Square ((Kinna Ploshcha) European Square (Yevropeyska Ploshcha)), at the corner of Vladymyrska and Kadetska streets (now B. Khmelnytskyi Boulevard), in Merinhivskyi Quarter and on the outskirts of the city.

\section{REFERENCES}

1. Antonovych D. (1925) Trysta rokiv ukrainskoho teatru. 16191919 [Three hundred years of Ukrainian theatre. 1619-1919]. Prague: Ukrainskyi hromadskyi vydavnychyi fond. (in Ukrainian)

2. Bernadska H. (1994) Kyivskyi miskyi teatr (do istorii orhanizatsiinykh form) [Kyiv City Theatre (on the history of event forms)]. Aktualni problemy orhanizatsii teatralnoi spravy [Actual problems of theatrical affairs organization]: tematychnyi zbirnyk naukovykh prats, Kyiv: Kompas. (in Ukrainian)

3. Karpenko-Karyi I. K. (Tobilevych, I. K.) (1985) Zapyska do z'izdu stsenichnykh diiachiv [A note to the congress of stage figures]. Tvory. Vol. 3: Dramatychni tvory. Statti. Lysty [Works. Vol. 3: Dramatic works. Articles. Letters]. Kyiv: Dnipro, pp. 279-288.

4. Katasonova T. V. (1995) Funktsionuvannia teatriv malykh form Kyieva u 1917-1918 rr. (sotsiokulturnyi aspekt) [Functioning of the variety shows of Kyiv in 1917-1918 (socio-cultural aspect)]. (Candidate of science), Kyiv: Kyiv University of Culture.

5. Khaichenko H. A. (1975) Russkiy narodnyi teatr kontsa XIX nachala XX veka [Russian people`s theatre of the late 19th - early 20th century]. Moscow: Nauka. (in Russian)

6. Khrenov N. A. (1981). Sotcialno-psikhologicheskie aspekty vzaimodeistviia iskusstva i publiki [Social and psychological aspects of the interaction of art and the public]. Moscow: Nauka. (in Russian)

7. Kudrytskyi A. K. (ed.) (1982) Kyiv: Istorychnyi ohliad: (Karty, iliustratsii, dokumenty) [Kyiv: Historical overview: (Maps, illustrations, documents)]. Kyiv: Holovna redaktsiia Ukrainskoi radianskoi entsyklopedii. (in Ukrainian)

8. Maryynskyi dvorets [Mariinsky Palace] (1985). Kudrytskyi A.V. (ed.) Kyiv: Entsiklopedycheskyi spravochnik. Kyiv: Glavnaia redaktsyia Ukrainskoi sovetskoi entsiklopedii, pp. 376-377.

9. Natsionalnyi tsyrk Ukrainy [National circus of Ukraine] (2012). Kyiv Velychne misto. Retrieved from: http://kiev-pravda.kiev.ua/ 2012/05/nacionalnij-cirk-ukraini/ (accessed 4 May 2019). 
10.Pietushkova M. (2019) Kyivska mala opera: vid budynku tverezosti do miskoho art-prostoru [Kyiv short opera: from the house of sobriety to the urban art space]. InfoLife. Retrieved from: https://life.informator.news/kyivs-ka-mala-opera-vid-budynkutverezosti-do-mis-koho-art-prostoru/ (accessed 4 May 2019).

11.Proskuriakov V. I. (2002) Pryntsypy rozvytku arkhitekturnoi typolohii ukrainskoho teatru [Principles of development of the architectural typology of the Ukrainian theatre] ( $\mathrm{PhD}$ Thesis), Lviv: National University "Lviv Polytechnic".

12. Rybakov M. O. (1997) Nevidomi ta malovidomi storinky istorii Kyieva [Unknown and little-known pages of the history of Kyiv]. Kyiv: Kyi. (in Ukrainian)

13. Sadovskyi M. K. (1956) Moi teatralni zghadky. 1881-1917 [My theatrical memories. 1881-1917]. Kyiv: Obrazotvorche mystetstvo i literature. (in Ukrainian)

14. Sherotskyi K. V. (1994) Kyiv [Kyiv]: putivnyk: repryntne vidtvorennia vydannia 1917 roku. Kyiv: Kobza. (in Ukrainian)

15. Teatry Kieva [Kyiv Theatres] (1985). Kudrytskyi A.V. (ed.) Kyiv: Entsiklopedycheskyi spravochnik. Kyiv: Glavnaia redaktsyia Ukrainskoi sovetskoi entsiklopedii, pp. 604-606.

16. Turkevych V. Pro teatr [About the theatre] Natsionalna Opera Ukrainy [Official site]. Retrieved from: https://www.opera.com.ua/ about/istoriya-teatru (accessed 4 May 2019).

17. Vsevolodskyi-Hernhross V. N. (1977) Istoria russkogo dramatycheskoho teatra. Vol. 1: Ot istokov do kontsa XVIII veka [History of the Russian Drama Theatre. Vol. 1: From the origin to the end of the 18th century]. Moscow: Iskusstvo. (in Russian)

Information about the author: Iudova-Romanova Kateryna, orcid.org/0000-0003-2665-390X $\mathrm{PhD}$ in Arts, Associate Professor Kyiv National University of Culture and Arts 36, Ye. Konovaltsia Str., Kyiv, 01133, Ukraine 
NOTES 
Publishing house "Liha-Pres"

9 Kastelivka str., Lviv, 79012, Ukraine 44 Lubicka str., Toruń, 87-100, Poland

Printed by the publishing house "Liha-Pres"

Passed for printing: January 27, 2020.

A run of 150 copies. 